
Digitized by the Internet Archive in 2008 with funding from Microsoft Corporation 


\section{EXPLORING EXPEDITION.}

\section{CORRESPONDENCE}

Between J. N. Reynolds and the Hon. Mamlon Dickerson, under the respective signatures of "Citizen" and "Friend to the Navy," touching the South Sea Surveying and Exploring Expedition; wherein the objects of the enterprise, and the causes which have delayed its departure, are canvassed. Originally published in the "New-York 'Times" of July, August, and September, 1837, and in the "New-York Courier and Enquirer" of December and January, 1837-38. 
The Bancroft Library University of California - Berkeley 


\section{E T T E R S., \& c.}

I.

To the Honourable Mahlon Dickerson, Secretary of the Navy. Sir,

In my opinion you hold one of the most important stations in this or in any other country. To fill it, a man should know all that is known of the seas, continents, and islands in the world. He should be acquainted with their commerce, their products, and with the character of their population. There have been men of mind in the office you now fill, who knew their deficiencies in these matters, and nobly laboured to induce the nation to permit thern to take the proper means to obtain this information for the benefit of the people and the department which they filled. You have succeeded them; and, permit me to ask, what have you done to carry out their plans, or to propose new ones calculated to infuse a proper tone and feeling in the service over which you preside? I shall speak plainly in these letters which I am about to address to you. I take no pleasure in the task, but feel it an imperative duty 10 do so. This is my prerogative as a native citizen of this country. The official acts of a public functionary may be fully canvassed by the humblest citizen; and while he confines himself to truth, and to the use of courteous and gentlemanly languagre, no merited censure can be charged to him. My feelings and my fame are identified with the glory of our arts, our arms, and our means of defence as much as yours or those of any other citizen, for these things belong to the whole country.

As far as our commerce and our navy are concerned, these are, for good or for evil, intrusted to you, and for the influence you exercise upon them you must be answerable at the bar of public opinion; that tribunal which, sooner or later, will do justice to the wronged, however humble, and cover, with its deepest denunciations, the unfaithful, however high in station!

In the freedom of my soul, I must say I have long doubted 
your capacity for the high office you hold; and I have often won. dered you did not gratify the whole community by retiring from duties you must find so difficult to perform, by secking that repose and quiet generally so grateful to man in the ninth septennial of human life.

I never heard a sentence from your lips, or read a paragraph from your pen, that gave me the impression that the compass of your mind, on public measures, was not better adlapted to razee or to cut dou'n than to build up and adorn! Still I thought that you would adhere strictly to the discharge of your duties, particularly where the responsibility of devising was taken from your shoulders, and rested in other quarters able to bear it; but in this I was unfortunately disappointed.

When you came into office, if you had looked over the files of papers in the department, you must have known that, ten years ago, as you have said, in the days of Madison, a plan was devised for an expedition to the South Seas; that memorials, petitions, and represcntations had come into Congress from all quarters, and seized strongly upon the attention of the enlightened members of that body, and that steps had been taken by them for such an undertaking. If the plan suggested was, from many circumstances, suffered to sleep a while. you know it was revived with fresh ardour in Congress, and acts passed for carrying the project forthwith into effect.

Your opposition to such an expedition was, I confess, undisguised. During the sessions of 1834 and 5 you were opposed to it in every shape and form; when the bill passed the Senate, you did all in your power to have it defeated in the house; recommending to members-"Strike it out, strilie it out !"

But you often declared that you should feel under obligations to carry into effect whatever Congress determined in regard to the subject. Have you done il? Are youl doing it? These are questions I have a right to ask; and they may be asked by an atlthority which will require an anower!

More than a year ngo the expedition was authorized, and the navy commissioners stated in their report to the president in January, 18:36, that the Mncedonian could be got ready for sea in ninety days; and how is it that she is now only ready to receire her men in June, 1537 ? 
Twelve months and more have elapsed, and the expedition still lingers, while the prospect of its departure seems to recede from the vision of the public. Was this delay for want of energy or from want of friendly disposition? The account of the expedition aroused the maritime powers, who were determined that this youthful nation should not run away with all the glories of discovery and examination; and while you have been weighing, and pondering, and devising means for delay and seeking for causes for procrastinating the whole enterprise, the French government has fitted out three expeditions into the South Seas; and with each a frigate-ay, a frigate-a machine so ponderous and ingulfing to your imagination! These well-equipped expeditions have moved to their destinations for the protection of commerce, for the security and defence of their fisheries, and for scientific purposes; and even a fourth is in a state of forwardness for the same noble purposes.

Why are we not then before them? Congress made the most ample provisions for the expedition. 'The people ask, and I as one of them, what under heaven has been the cause of this procrastination? Will the energetic people of this country, who, in 1797, when we were insulted by the French directory, spread over the forests of our country, bowed the oak beneath the axe, built sloops of war, armed and manned them, and in less than a hundred days from the orders given to build were pouring their thunders into the French cruisers among the West Indian Islands; can these men and their descendants brook such a delay without inquiry?

But, for the present, I will not pursue this inquiry farther. You, under the specious appearance of sincerity, opened a correspondence with some of our learned societies, asked them to recommend suitable persons to form a scientific corps, which the executive determined should accompany the expedition. Gentlemen were recommended and selected; men sharing largely in the confidence of men of science, and burning to distinguish themselves in their departments.

I have heard it intimated that you had some pretensions to science, and that you were a member of the philosophical society. From that circumstance I should have expected that you would deal out a different measure of justice to the members of the scien- 
tific corps. Why have they not been called together, and their duties assigned them, and facilities given for the various and extensive preparations necessary for their respective departments, in pursuance of the written request or order of the late energetic executive, under date of February 25th last? No one knows better than you that the late executive was fully resolved that the expedition, both in its civil and naval departments, so far as he was concerned, should go to sea wanting in nothing that could tend to promote its ultimate object and triumphant success. It never occurred to his lofty and indomitable spirit that petty excuses would be made by any officer of his for delays in a great undertaking; nor did he wish that the scientific corps should be sent on board at the hour of sailing like a guard of marines. Of his share in this expedition I shall hereafter have occasion to speak. You cannot soon forget it, nor the inanner in which he used to stir you up, as you have often complained of what he made you do. Well do you linow that even in sickness he did not lose sight of the expedition; and, had his wishes been complied with, lhe expedition would now be doubling the cape, and every one engaged in the enterprise full of hopes of having immediate opportunities of fulfilling their country's expectations.

I shall reserve many things for future consideration, and now pass 10 your last attempt to strangle the expedition. Now, at the elcrenth hour of the thirteenth moon of the expedition, a new device is got up by you, if not to destroy it altogether, for that you cannol do, yet to cut it down, derange its plans, and thereby render it inadequate to meet the expectations of Congress, of the late executive, and of the whole country.

You have now appointed a board of naval officers, consisting of Commodores Chauncey, Morris, Warrington, Patterson, and Wadsworth, to assist you in making up your mind on the proper means requisite for the exploring expedition. 'These are all honourable men, whose merits and virtues have been tried and found true and trusly in days gone by ; and a most ungracious duty have you assigned them. Deceive not yourself, sir, the intelligence, the spirit, and pride of the country have-been awakened upon this subject, and will not sleep again; and long, and deep, and withering will be the denunciations against the man or men who shall lay Vandal 
hands upon this enterprise, in the success of which the honour of our courtry is so deeply concerned.

But, sir, have you presented the whole case to this board in a proper light? I fear not. I have been informed, from good authority, that the whole case has not been presented to them by your instructions. For what was this board instituted (stripped of all disguise) but to sit in judgment upon the deliberate opinions of the people of the United States in Congress assembled? Will these officers thank you for such an unenviable office? It will be seen, if they are ready to say, that Congress knew nothing of the subject, and that the force authorized by that body, and deemed necessary by President Jackson, after he had examined more thoroughly into the objects of the expedition than you have ever done, was too large for the attainments of the objects proposed.

Had the duties of this board been confined to subjects relating to naval matters, to the examination of the vessels, for instance, there would have been no complaint; but you have asked them to revise the act under which you have proceeded. Every one knows that the force to be employed on any enterprise must depend entirely upon the objects to be accomplished by it. Had you given this board instructions, fully and fairly setting forth the great labours the expedition was expccted to perform, which have been so clearly set forth in the proceedings of Congress that he who runs may read, the country would have had no fears of their reducing the force provided and deemed indispensable by the friends of the expedition; but, if confined to your limited instructions, that board can only take a partial view of the subject, and, of course, give you but a partial answer.

If there be any member on that board who thinks the present force is unnecessary for all the great purposes contemplated by Congress and the friends of the measure, the public would be much indebted to him for a programme of his views; I am no advocate for a redundant and proud equipment, and, for one, should be glad to see them.

But, in sober truth, what instructions have you given this board? Will you tell the public the whole story, and let the Senate, and House of Representatives, and the friends of the expedition become thoroughly acquainted with all your views? Perhaps this would be asking too much; but, certainly, in this case you are bound to 
furnish us with all your doings fairly and above-board. Secrecy is unworthy of you and the station you occupy. You have instructed this board in such a manner as to shackle their opinions, if I am not grossly deceived. Is it not something in this contracted form?

"The objects of the expedition are to explore the seas of the Southern Hemisphere, more particularly in high latitudes, and in regions as near to the South Pole as may be approached without danger; to make, in the regions thus to be explored, all practicable surveys and observations, with accurate descriptions of the same, so far as they may be connected with the geography or hydrography by which the interests of commerce and navigation may be promoted." Perhaps you may have dropped a word about science at the close, and intimated that the ressels might, during the cruise, go north of the line, though for what purpose you do not say.

'This, if I am not misinformed, is the breadth, and length, and alitude of your instructions, if not the very words.

Why did you forget-no, why did you omit the major part of your subject? the great commercial interests anong the islands of the Pacific, and the thousand ways in which those noble interests might be examined, extended, and secured by this expedition? Have not the memorials from Nantuclict, New-Bedford, NewLondon, Salem, and other great commercial places, given you any light upon the subject? Have they not, "in thoughts that breathe and words that burn," told you, through Congress, the dificulties, the dangers our fisheries have to encounter in those seas? Have they not, in the deep impassioned feeling of their hearts, implored their country to look after their brethren in bondage on desolate or savage islands? And you, in your instructions to this gallant board, have mentioned but little more than the object of getting as near as possible to the South Pole, and there to malie surveys for the benefit of commerce! 'This same plan of misrepresenting the objects of the expedition was tried by its opponents last winter before Congress, and failed. Do you expect to be more successful in urging the same plea before this board? I am not done with this point yet. Every friend to the expedition can bear witness that you have misrepresented his wishes in regard to the whole enterprise. In what light do you place the merchants and others 
who have addressed Congress on this subject, and how do you treat the members of that body who voted for the expedition, by stating that the things you mentioned to the board of officers were the great objects of their solicitude and protection. Did you suppose, when you penned those instructions, that you were complimenting the late executive by saying that the object of the expedition was to go as near to the South Pole as possible, and that, for that purpose, he had been so unacquainted with his duties as to assign the present force. I do you no injustice; such is the plain interpretation of your acts. The decisions of that executive have been universally approved by the friends of the expedition; its enemies alone are hawling at it, wishing to derange and alter what they have not the power entirely to destroy. You respected, or affected to respect, that distinguished man's opinions when he was in power. Have you forgotten him and his opinions in the short period of four little months?

I have now stated a few outlines of the case, simply that the people may inquire of your doings, or your undoings, or your nondoings! It is with your acts I am engaged; with your motives I have nothing to do. I leave them to the conjectures of the public, and to the depths of your own bosom.

If you, by the management you have adopted, can draw from the board you have appointed such a report as will suit your views, and be made the pretext for cutting down the expedition, you will know that such a course will not justify your conduct at the public tribunal to which I have summoned you, and intend to hold you, until you have put in your plea of justification and ventured the issue upon it. I am but a citizen, holding no office of honour, but I know my rights, and, knowing, "dare maintain them." I, as a citizen, have, by the constitution, the privilege to call your attention to your duties. This is a writ of right, I ask no leave of court for filing it ; and shall fear no authority in pursuing my own course in the premises. The high hopes and deep solicitude of the nation have been trifled with by you alone ; every other public functionary has given his consent, or been silent. Do you aspire to the enviable fame of having thwarted the nation in a plan for its benefit and distinction? If you do, you may go down to posterity with all the honours you deserve.

I have said your instructions to the board were a perversion of 
the great objects of the expcdition; that you had brought before them but a partial view of the subject; and in my next letters I shall proceed to prove them so.

\author{
Very respectfully, \\ Your obedient scrvant and fellow
}

CITIZEN.

New-York, June 29, 1837.

II.

To the Honourable Mahlon Dickerson, Secretary of the Navy. Sir,

You will remember the conclusion of my last number. It was there intimated that your instructions to the naval board did not convey an impartial and just view of the great objects of the expedition. I promised that in my next I would prove my assertion, and shall proceed to do so.

Fortunately for my purpose, there are ample records which bear directly and luminously upon the point at issue. 'To these documents I shall mainly confine myself; because, being official and on file in the naval department, you can have access 10 them at any moment, and can therefore the more easily judge of the fairness of the testimony I shall extract from them. No one, sir, can turn over the pages of these documents and fail to be at once convinced, even against his will, that the whole action of Congress has been based upon memorials from various sections of the country, and more especially from that portion occupied by our fellow-citizens interested in the whale-fishery, and the multifarious traffic carricd on among the comntess islands of the grcat North and South Pacific and Indian Oceans.

The memorials to which I refer are now before me. Among them is one from Nantucket as far back as November, 1828. As regards the whale-fishery, the memorialists remark:

"Whether viewed as a nursery of bold, hardy seamen, or the employment of capital in one of the most produclive modes, or as furnishing an article of indispensable necessity to human comfort, it seems to your petitioners to te especially descrving the public 
care. The increased extent of the voyages now pursued by the trading and whaling ships into seas but little explored, and in parts of the world before unknown, has increased the cares, the dangers, and losses of our merchants and mariners. Within a few years their cruises have extended from the coasts of Chili and Peru to the Northwest Coast, New-Zealand, and the islands of Japan. This increase of risk has been attended by an increase of loss. Several vessels have been wrecked on islands and reefs not laid down on any chart, and the matter acquires a painful interest from the fact that many ships have gone into those seas, and no soul has survived to tell their fate. They therefore pray that an expedition may be fitted out under the sanction of government to explore and survey the islands and coasts of the Pacific seas, and, as in duty bound, will ever pray," \&c.

This memorial, emanating from an intelligent, hardy, industrious, and enterprising people, was accompanied by many similar petitions from other places, all breathing the same spirit, and couched in the like simple yet forcible language. It never occurred to these petitioners that their whaling operations, extending throughout the numerous groups of islands stretching from the western shores of South America to the confines of Asia, could be particularly benefited by surveys "as near the South Pole as can be approached without danger!" 'The committee on naval affairs had charge of the memorials adverted to. What thought they of the matter? Seven out of nine of their number were in favour of the expedition. General Ripley, of Maine, made the report on the 25th March, 1828. He began by allusion to the weight of character of the memorialists, and the importance of the opinions they expressed, and concluded in the following words:

"The dangers to which an immense amount of property is exposed, as well as the hazard to human life, for the want of knowledge by more accurate surveys of regions to which our commerce is extending, and the probable new sources of wealth which may be opened and secured to us, seem to your committee not only to justify, but to demand the appropriation recommended. They therefore report a bill for that purpose."

Are the dangers to which this immense amount of property is exposed, and the hazard to human life, here spoken of as existing, in regions "as near as can be approached to the South Pole?" 
Would surveys in that quarter render the property endangered more secure, or add to the safety of our mariners by restraining the untamed savage of the tropic isles?

Between the committee and the then secretary of the navy an interchange of opinion took place. The latter said-

"I entertain the opinion that such an expedition is expedient. My reasons are briefly these: 'That we have an immense and increasing commerce in that region, which needs the protecting kindness of goverument, and may be greatly extended by such an expedition. 'The commercial operations carried on in that quarter are difficult and hazardous. 'They are correctly represented in the memorial of the inhabitants of Nantucket, to which I would refer, as well as to some of the many other memorials which have been addressed to Congress on this subject. It would seem wise in government to render these commercial operations less hazardous and less destructive to life and property. The commerce in the Pacific Ocean affords one of the best nurseries for our seamen. An expedition such as that proposed would be calculated $10 \mathrm{in}$ crease that class of citizens; an increase in which the government and nation are deeply interested."

It is unnecessary to dwell longer upon the records of that day. Sufficient information has been given to leave no doubt of the opinions then entertained by men who had thoroughly investigated the subject. You were at that time a member of the United States Senate; but, as the affair never came fairly before that body for discussion, you may have forgotten these matters. I proceed, therefore, to a later period, embracing the action of Congress since you have been secretary of the nary. Of the transactions of the legislature within that interval I camnot suppose you uninformed, because such want of information would almost imply a dereliction of public duty.

Mr. Pearce, of Rhode Island, to whom the comntry is much indebted for the ability and zeal with which he adrocated this measure before the committee on commerce, on the seventh of February, 1835 , made a long report, which was accompanied by a bill providing for an expedition. He commenced by stating that the number and character of the memorialists, together with the opinions they had expressed upon the subject of their petition, had callod the commituce to an attentive and careful consideration of 
the objects to be attained by the projected undertaking, as well as of the facts and reasoning adduced in its favour. He then went into a full examination of our great interests in the North and South Pacific and Indian Oceans, and pointed out the numerous ways in which those interests might be rendered more secure, as well as greatly extended, by an efficient expedition. He noticed the action of the legislature of his own state during the October session of 1834, in which that body recommended the enterprise to the favourable consideration of Congress, as "highly important to our shipping and commercial interests." What shipping and commercial interests have we near the South Pole? But the legislature did not, perhaps, exactly understand the import of the language they used.

To the memorial from the East India Marine Society of Salem, Massachusetts, the committee made special reference. That society comprises among its members a larger number of practical seamen than any other in the United States. By its constitution no one is eligible to membership who has not doubled either Cape Horn or the Cape of Good Hope. 'The language of such a body of men is the language of experience. They ask that an expedition be fitted out under the sanction of the government, the objects of which shall be to examine the numerous places of trade already visited for commercial purposes by our enterprising citizens, and to open new channels for the extension of traffic by the survey of such groups of islands in the North and South Pacific Oceans as are imperfectly explored or entirely unknown; to as. certain their true positions on the charts; examine their harbours and mercantile or agricultural capabilities ; and to bring about such a friendly intercourse with the natives as shall prevent the effusion of blood.

'They speak of having themselves been in those seas, and of experiencing, in severe losses and painful solicitude, the want of national protection-protection from the dangerous reef, guarantied by a well-ascertained knowledge of its position, as also against savages, who can only be deterred from lawless violence by being made sensible of our power to restrain and punish them.

They have "seen and felt the dangers our vessels are exposed to for the want of such protection as an expedition fitted out fur the express purpose alone can give." They enforce their views 
by calling the attention of Congress to a single point, the Feejee or Beetee Islands. This group consists of sixty or more in number, of which there is no chart pointing out their harbours, shoals, \&c., and yet no less than twelve vessels from the single port of Salem have been engaged in procuring from this cluster bichele-mer, shells, and other commodities, in exchange for which eastern cargoes are brought into our country, thus contributing no inconsiderable amount to our national revenue. Nany mariners have been killed by the natives, their vessels lost or damaged, and the sum total of losses would go far towards paying the expenses of an expedition.

Are the Feejee Islands near the South Pole?

The committee embraced in their report a letter from one of the most practical, liberal-minded, and intelligent officers in our service, Commodore Downes. It was written at the request of a member of Congress. Commodore Downes had had some cxperience in the navigation of the less frequented parts of the Pacific at an early period of his life. During his voyage in the Potomac an opportunity offered to add materially to the knowledge acquired in former years. While circumnavigating the globe, in accomplishing which he crossed the equator six times, and varied his course from forty-two degrees north to fifty-seven degrees south latitude, he had never found himself beyond the limits of our commercial marine! 'The accounts given of the dangers, privations, and losses to which our shipping and seamen are exposed from the extension of our trade into seas but little known, so far, in his opinion, from being exaggerated, "would admit of being placed in bolder relief, and the protection of government implored in stronger terms." He spoke from practical experience.

Pursuing the labours of the committee, you will find that which must startle you, when contrasted with some of your recently expressed opinions. 'That body hold up to your view the policy adopted by other countries for the protection of their fisheries, and show how these very fisheries have been extended by cxploring expeditions. 'The British nation has disbursed millions in bounty to its whalers. 'The American whaler has received no bounty. He requires none. He aslis of his government only pintection.

More especially, permit me to call your attention to the very 
last paragraph in the able report to which I have alluded; it is much to the point, and you may draw instruction from it. Yea, more, it will furnish you with an argument to refute the contemptible fabrication of the weak marplotting enemies of this truly na tional enterprise, who, in the face of two hundred pages of printed documents, have had the effrontery to say the expedition would have little or nothing to do with protection of commerce in the regions to be examined. I will give the authors of this device a withering review before I have done. Let them prepare for it. I know them, and may feel it my duty to drag them from their dark retreats, perfectly regardless who may be found in their company, or what aspect they may wear when exposed to the fair face of day.

The advocates for the expedition, whether in or out of Congress, have ever been ready to meet their upponents in open and manly discussion; but they have had little of this kind of opposition to encounter. What has been frank, bold, and above-board on the one hand, has been met by cowardly, ignorant, or wilful misrepresentation on the other. Those who originated, anthorized, and sanctioned the enterprise are responsible to the country for its results. In courtesy, in common justice, they should be allowed to influence its organization, and to employ the force which, in all sincerity, they deem indispensable to its ultimate and triumphant success. Yes, sir, the objects of the voyage, the plan of the yoyage, and the force to be employed, are defensible, have been defended, and can be defended before the nation and the world. Have their opponents met them in argument? They have not, they cannot, they dare not, under the responsibility of a name.

But to the report. "While your committee, in coming to their conclusion in recommending such an expedition as has been prayed for by the memorialists, have been influenced by commercial views, and place the policy of the measure solely on these grounds, they are not indifferent to the valuable fund of knowledge which may be gathered during the voyage, and which, properly analyzed and written out, may be interesting not only to the American people, but to the whole civilized world."

Here I might pause and appeal to the intelligence of the country if I have not made out my case, and convicted you of having misrepresented-I do not say intentionally-the true objects of 
the expedition in your instructions to the board. Let the members of that board report. For the objects to be attained you state the force designated is too large. For those objects, as understood by Congress and the whole country, neither you nor they will venture to reduce it.

I am prepared to meet you, or any one who thinks with you, in argument, and to demonstrate that the present force is wisely proportioned to the accomplishment of the ends proposed, or, if altered, should be increased rather than diminished. Before I have done with you I will go still farther, and prove that you are in honour bound not only to cease all opposition, but to fit out the expedition on its present plan, and that you cannot persist in your present course without a sacrifice of honour which would tarnish the reputation of any man in the common concerns of life.

This is strong language, sir, but I know what I am saying, and hold myself responsible for what I have said. In my next I shall bring the matter nearer to your department in the further examination of your precious instructions.

Very respectfully,

Your obedient servant and feliow

New.York. July 1, 1837

CITIZEN.

\section{III.}

To the Honouiable Mahlon Dickerson, Secretary of the Navy.

\section{Sir,}

I proceed to a further examination of your precious instructions to the naval board, as promised in the conclusion of my last letter. I feel humiliation in the task of holding you up to the public gaze as unfaithful to your duty in neglecting to execute a twice-repeated law of Congress, unfortunately for the honour of our country intrusted to your hands. I still deal with your public acts. In the private walks of life it is said you are amiable and kind. I am glad that it is so. To your observance of the courtesies of your office I can mysclf bear testimony. I can dwell upon them, and upon the domestic virtues claimed for you, 
with the same kind of fervid pleasure the weary traveller may be supposed to feel when gazing upon some green spot and gushing fountain in the midst of the desert, while all around is barren and unproductive-a hungry soil, that swallows up the fattening showers, poured by bounteous Heaven upon its steril bosom, but in return gives forth nor fruit, nor flower, nor herb to gladden the eye and cheer the interminable waste.

But to my task. Do you, sir, remember, that on the 23d of January, 1835, a call, in the form of a resolution, was made on you by Congress for an original report of J. N. Reynolds, Esq., on the "Islands, reefs, and shoals of the Pacific, \&c., \&c. ;" and that, on the ensuing day, you transmitted said report, with this note- "When no longer required, it is respectfully requested it may be returned?

\section{Mahlon Dickerson."}

Allow me, sir, to ask you, in the most respectful manner, what that paper contained. You cannot plead forgetfulness of its contents, because it passed through your hands in manuscript form, and soon after was returned to your department a printed document of some forty or more pages. You know, sir, that document embraces a list of islands, reefs, and shoals discovered by, and noted in, the logbooks of our whalemen during the last thirty years, as they gradually, in the pursuit of their vocation, followed the great monsters of the deep into unfrequented seas and remote parts of the globe.

You further know, sir, that that document contains irresistible evidence of the necessity and importance of the labours to be performed by the expedition among the thousand islands erroneously laid down in our charts; and among others - to the extent of morc than half that number-not laid down, nor to be found on any chart, however recent or improved its construction. This was the light in which the document was viewed and commented on by committees who made reports, and by members who alluded to it in their speeches on the floor of Congress. And yet, sir, in the face of all this, and of all else I have stated and have to state, you, in your official capacity as secretary of the uavy, have told the board to look mainly to the means of getting to the South Pole or near it, and then, forsooth, to see if the present force $b_{e}$ not too large for that single object! 
Are you not aware, sir, that, throughout those wide-spread seas, speckled with countless islands, we have, engaged in the whalefishery only, nearly one hundred and fifty thousand tons of shipping, valued at twelve millions of dollars, and giving ensployment to not less than ten thousand men, to say nothing of the increasing traffic in treasures gleaned from coral reefs, and in the productions of the islands? Are you not cognizant of the fact, that the combined interests of all the other commercial nations of the earth do not equal ours alone in those seas? You cannot but know, sir, that these islands are inhabited by every variety of savage man; that our vessels have been wrecked among them, often attacked, and sometimes cut off by them; our mariners massacred, or, if spared, spared only to wear out a wretched existence, in the captives' hopeless prayer that the honour and justice of their country might be aroused to rescue them. If the supplications of disconsolate and heart-stricken parents, whose sons are in bondage, could move you, how soon would this expedition depart on its errand of mercy, of utility, and national renown! All these things are known to you, sir, and yet you have not alluded to one of them in your instructions to the naval board, in which you profess to set forth the objects of the enterprise. Why, in the name of all that is high, and noble, and manly, have you thus compromitted your official character? I feel compassion for you in the unpleasant predicament in which you stand, and, were I to consult my inclinations rather than my duty, would willingly leave you in the hands of the public, and to the bitter reminiscences of your own mind. But this may not be; you are a public man, and the public good requires that I should go on.

Is it not within your knowledge, sir, that our whale-ships often, nay, daily, pass by islands in those seas to more distant ports for refreshments; while those very islands, if surreyed, their harbours pointed out, and the natives awed into respect by a judicious display of our power, would furnish in abundance the necessaries or refreshments required? Are you to be informed, sir, that all barbarians estimate the power of others solely by contrasting that power with their own; and that many of these islanders have learned to distinguish between the flags of different countries, and to deride one nation or fear another, according to the weakness or strength which each displays in its naval armament? 'This fact 
was illustrated in 1824, when the British government sent Lord Byron, in the frigate Blonde, to the Sandwich and other islands. What was the effect produced on the minds of the savages by the presence of that ship? So firm was their impression that there was no power on earth equal to the English, that the American residents and traders in that quarter wrote to Commodore Hull, then commanding the Pacific squadron, requesting that he would send a frigate for the sole purpose of doing away or modifying the feeling which the visit of the Blonde had produced; and you may lay your hand upon the evidence of this fact in the archives of your department. Your predecessor sent the frigate Potomac to Quallah-Battoo to chastise the Malays, whose hands were red with the blood of our countrymen. Her presence on that coast, I assert without fear of contradiction, made a more lasting impression for good on the inhabitants than the appearance of a dozen sloops-of-war could have done. Had you been then in office, the ghost of La Perouse * * * but I forbear.

I presume you are not uninformed that the French have, probably, less than one tenth of our interest afloat in the North and South Pacific Oceans; and yet they have despatched three frigates to these seas avowedly to protect and extend their trade and fisheries, and to subserve the purposes of science. The people of this country, on the other hand, have the melancholy spectacle presented to them of your efforts to cut down the first similar national expedition undertaken by this great republic, and that, too, in the very face of a solemn law of the land!

I mentioned the name of La Perouse. 'The loss of his frigate some half century or more ago has been a stereotyped argument assumed by you and a few others against the employment of a small thirty-six gun ship. But now the tables are turned; for, if the wreck of the ship alluded to be quoted as a precedent against the employment of vessels of that class, it may be fully met by the fact that France has since despatched three frigates into the same seas; thus leaving you no ground to stand upon, save your paternal solicitude for the lives of those who may embark!

Is it possible, at this late period of your life, with all your experience, and the opportunities you have had to expand your mind in reflecting on and investigating the great concerns of nations, you have still to be informed that, in case of a war between our 
country and any of the first maritime powers of Europe, this government would be compelled to dash her frigates, if not her larger vessels, into the waters to which I refer? 'There she has a commerce; and where her commerce is, there must be her navy and her ocean conflicts also. What would be thought of your present policy in such an emergency? and what would be thought of those naval officers who have echoed your sentiments upon the subject? We are now at peace with the world, and this is the season to acquire that knowledge which would most assuredly be needed and most valuable in the event of war.

One thing is certain; were I the enemy, I should count upon rich prizes in the Pacific before any vessel fitted out by your direction could reach me. I should anticipate at least twelve months uninterrupted pickings among the American whalers; and even then, in consequence of La Perouse having been lost, I should cxpect nothing more formidable than a sloop-of-war to come after me among the islands !

But why should I consume more time in exposing this part of your official delinquencies? You cannot defend yourself. Your maladministration is indefensible. Why, sir, you cannot open the document containing the authority under which you act without sceing, on every page of the Senate's report, a complete refutation of the extraordinary position you have assumed.

You cannot look over the columns of speeches made by members, explaining the true objects of the enterprise, without meeting a withering rebuke. Allow me to commend to your attention a speech of singular ability, made on this subject by Mr. Hamar, of Ohio; it has been published in all quarters of the Union. Perhaps the enlarged and statesman-like views it exhibits may render it, though not incomprehensible, at least unpalatable to you. Nor does Mr. Hamar stand alone. Mr. Vinton, indeed the whole delegation from the state of Ohio, have ever stood as one man upon this subject. 'Their weight and influence have told, and, if need be, will again tell!

But the most extraordinary part of this story remains to be disclosed. After all we have seen in the character of your instructions to the naval boarl, and the object proposed by those instructions, what will the community think when informed of the fact that, for a considerable time after the expedition had been 
authorized at the first session of the last Congress, you, the HoN. Mahlon Dickerson, Secretary of the Navy, ridiculed the very idea of undertaking to explore high latitudes south! To give an instance, sir. In your office, on one occasion, while in conversation with a gentleman of unimpeachable veracity, you said it was all nonsense to talk about going to regions near the South Pole; and, to use your own, not very classic, language, that "none but a d-d fool would think of it! ! ! ! "' And yet, for some mysterious and inscrutable purpose, it now suits your pleasure to pretend that this is the great leading aim and object of the enterp: ise !

Thus do you stand, sir, before the American people-an official spectacle, such as has been rarely, if ever, before looked upon. It is no fancy sketch; would to Heaven, for your own sake and that of our common country, that it were. I have charged you before the tribunal of the public with dereliction of duty; with having misrepresented the objects of the expedition in your instructions to the naval board; and with having intended, by such misrepresentation, to draw from that board a report, to be used as a pretext for reducing the force authorized by law to be employed in the enterprise. Whether I have not fully and triumphantly made out my case, I appeal to the intelligence of the community; to the members of Congress who authorized the outfit; to the late executive, and those members of his cabinet who took an interest in it; and to the conductors of the public press in whose columns the great national purposes of the expedition have been so often discussed and so generously supported.

You will hear from me again.

Very respectfully,

Your obedient servant and fellow

New.York, July 8, 1837.

CITIZEN. 


\section{IV.}

To the Honourable Mahlon Dickerson, Secretary of the Navy. Sir,

"You will hear from me again" were the concluding words of my last letter. With that letter terminated all $I$ deemed it necessary to say, in a connected form, in relation to your extraordinary instructions to the naval board. In following up the train of your official doings, though I may now be compelled to take a somewhat wider range, I shall, nevertheless, endeavour to adhere closely to the text and closely to you.

On the 10th of May, 1836, the bill authorizing the expedition, in despite of all your efforts to defeat it, passed both houses of Congress, and receiving, as it did, the cordial sanction of the president, became the law of the land. No one anticipated further difficulty. If you, however, entertained honest convictions against the utility of the enterprise, or apprehended the good it might do would be purchased at too dear a rate, you had a fine opportunity of enforcing those convictions while the bill was under deliberation; and that you did thus exert yourself, with an energy which you have seldom, if ever, manifested in the discharge of your official duties, was apparent at the time to every observer. But when, as I have stated, the whole matter was settled by Congress, no person anticipated any further opposition from you. Your duty then became simply an executive duty; and whether the expedition was upon too large or too small a scale, whether it would cost one hundred thousand or five millions of dollars, were contingences for which you were not responsible, in which you had no official concern, and about which you had no right to trouble yourself.

May and June passed away, and no step had been taken by you to put in train the preparations for the expedition. Fifty days had thus been lost. You now began to speak plainly, and to hold the language that twelve months would be necessary to complete the outfit. Yes, sir, twelve months was the period you named, and this, be it remembered, was before you could have foreseen any of the difficulties to which you have since ascribed 
all the subsequent delay-with what justice will be hereafter shown. 'This procrastinating policy, thus early developed, met with no favour from the president; and it was not until he had taken the matter in his own hands and overruled you, that, for the first time, you made yourself acquainted with what the law required you to do. Yes, sir, amid the pressure of executive duty incident to the close of a long session, and while on the eve of his departure for Tennessee, the president put you into the traces, and directed the whole plan of preparation to be carried immediately into execution, in a spirit and on a scale commensurate with the character and resources of the country, as will be seen by the following, which appeared in the Globe on the 13th of July, 1836.

"We learn that the president has given orders to have the exploring vessels fitted out with the least possible delay. The appropriation made my Congress was ample to ensure all the great objects contemplated by the expedition, and the executive is determined that nothing shall be wanting to render the expedition worthy the character and great commercial resources of the country.

"'The frigate Macedonian, now undergoing thorough repairs at Norfolk, two brigs of two hundred tons each, one or more tenders, and a store-ship of competent dimensions, are, we understand, the force agreed upon, and to be put in a state of immediate preparation. Captain Thomas Ap. C. Jones, an officer possessing many high qualities for such a service, has been appointed to the command; and officers for the other vessels will be immediately selected.

"The Macedonian has been chosen instead of a sloop-of-war on account of the increased accommodation she will afford the scientific corps, a department the president has determined shall be complete in its organization, including the ablest men that can be procured; so that nothing within the whole range of every department of natural history and philosophy shall be omitted. Not only on this account has the frigate been selected, but also for the purpose of a more extended protection of our whalemen and traders, and to impress on the minds of the natives a just conception of our character, power, and policy. The frequent disturbances and massacres committed on our seamen by the natives in. 
habiting the islands in those distant seas makes this measure a dictate of humanity."

When this article appeared, why did you not remonstrate with the president, and show him that he had misunderstood the true objects of the undertaking ; that the allusions to our "whalemen," to the "protection of commerce," to the impression contemplated to be produced on the minds of the natives by a proper exhibition of our "character, power, and policy," could not belong to an expedition intended only for high latitudes? How can you answer to your country for having omitted, at that early period, to set the head of the nation right, and to correct the strange notions he had formed about the purposes of the voyage?

'To be serious. Iou know, sir, it was the wish of the executive at that time to be able to say, in his next annual message to Congress, "The expedition has sailed;" and had the directions which he then left been obeyed in good faith, such had been his language when the national legislature again convened; or, at any rate, long since had the vessels designated been ploughing the waters of the Pacific. Sir, in your heart you know I speak the words of truth and soberness!

In October the president returned to the capital. Do you remember his astonishment and displeasure on learning the little progress which had been made during his absence? You had, however, by this time got hold of an cxcuse for the delay-the impossibility of procuring men. I will cxamine this impossibility anon. It is true, you had despatched an agent to Europe to procure instruments, and had sent a circular to our learned societies, asking their advice and opininins as to the organization of the scientific department of the enterprise. You received from them able reports; but the reading of many of them, if you have read them at all, has been a labour of very recent date.

'The season was now far advanced, and all hope of sailing during the autumn had passed away. Congress was soon to assemble, and it was apparent to all that the whole subject would come once more before that body. 'That you again prepared to renew your opposition with new expectations of success, your acts, as I shall examine them, will abundantly prove. Did you ever hear of any consultutions having taken place before the precise plan of attack was agreed upon? Perhaps it is hardly fair to question 
you too closely upon this point; so I will waive it, and allow your official acts to speak for themselves, as I shall take them up in my next letter.

It was now well ascertained in the naval service that you had no partiality for the expedition, nor have you ever been known to manifest any feelings of that nature towards those by whom it was commanded. He who could depreciate the high objects, or find most fault with the plan and scope of the measure, either in toto or detail, was sure of finding in you a most graciously-condescending and patiently-listening auditor. You have often said that the officers of the navy were opposed to the expedition. Did man ever labour more zealously in any cause than you have done to produce this very opposition? Why, sir, the scientific corps has frequently been held up by you as an encroachment upon the rights of those officers, and you have as frequently stated that to be one reason why the whole affair was so unpopular with them. This preposterous sentiment, so freely and perpetually expressed by the head of the department, could not fail to produce some impression, especially among the less informed and less considerate portion of the profession. You even went farther, and maintained that the officers had a right, if not to fix the salaries which should be allowed men of science, at least to protest against their compensation exceeding a certain amount per annum. I am not aware how many you may have found to echo this opinion, as I have never myself heard any such language from the profession.

You know how many there are and who they are who hold such doctrine. I have no wish to learn the former or designate the latter; but, taking you as the authority, we are bound to believe that such sentiments are entertained, and that the ardour of the service has been somewhat cooled towards the enterprise on that account. Permit me to say, sir, that the worst enemy of the navy could adopt no measure more injurious to its interests than that of fomenting causeless jealousy between the officer and the citizen in the few and far-between instances in which they are brought together on duty. The title of citizen, sir, is a proud title. This is a country of citizens. Citizens make the navy, increase or diminish it at their pleasure, appoint and support its officers, and will judge them!! For every year he is on active duty, an officer may be two on shore, receiving pay in the latter 
as well as in the former case. Of this the citizens make no complaint. 'They have created a navy for great national purposes, not for individuals. If the more intellectual, better informed, and, of course, more influential portion of its officers did not form a barrier against those, to the service, suicidal pretensions which have received your sanction, then, indeed, there might justly be much apprehension for the success of the expedition, and still more for the prosperity and improvement of the navy. Let those you have encouraged in these extravagant opinions, be they few or many, of high rank or low, assume to themselves an imagined importance, and, with supercilious, domineering tone, attempt to sneer at civilians and oppose their employment-as, according to you, they have already done-on board public vessels where their country requires their services, and where their right to fill certain stations is not by courtesy or sufferance, but derived from authority unquestionable as that of the commander himselffor both emanate from the same source; let them indulge in illiberal, contracted feelings of petty jealousy against the appointment of citizens to their appropriate provinces, and they will soon find themselves in the hands of a giant, who knows his power and will use it !

It is no reproach to the gentlemen of the navy that they have not the varied scientific knowledge required for a national expedition such as has been directed by Congress to be organized. They are only open to censure when, forgetful of their own noble profession, they claim to assume the performance of duties for which their previous training and distinct line of action have left them totally unqualified. Our public vessels have been round the world, and our officers in them, among islands and in places rarely visited; but what contributions to science have resulted? Where is the record to which reference can be made, and which affords a sufficient guarantec that all that is required in the department of science could be accomplished by the profession, at a time, too, when the whole range of that department has assumed such a determined accuracy of detail that the slightest blunder would subject us to the ridicule of the scientific world? Sir, no such record exists ; and, until it does exist, it is folly-and, I can readily conccive, must be humiliating to the abler portion of the service-to hear such silly pretensions set up by their weaker 
brethren, though such pretensions be endorsed by you, the honourable secretary of the navy.

But I will not dwell long on a position so untenable. It was only assumed, in common with many others, to increase the weight of your opposition to the measure at the last session, by adding professional prejudice to your other weapons of attack.

How infinitely more worthy and becoming in you, the head of the department, had you either checked the first expression of this disorganizing spirit, or given it a more noble direction. Why did you not point out to these gentlemen that it would soon be regarded as a reproach to the navy if a hydrographical bureau were not established in your department? But perhaps we should overlook your omissions of this nature, when the increase of the forces to be led against the expedition was the paramount consideration in your mind.

I do not feel it a part of my present duty to diwell particularly on the various difficulties which have occurred between the naval officers, although I think I could give the public some additional light as regards the part you have had in fomenting those dissensions, and shall do so whenever such a course may seem expedient or necessary.

In my next I shall take up that section of your annual report which alludes to the expedition.

Very respectfully,

Your obedient servant and fellow

CITIZEN

New-York, July 17, $183 \%$.

\section{V.}

To the Honourable Mahlon Dickerson, Secretary of the Navy. Sir,

In your annual report to the president, under December 3 , 1836 , we find, for the first time, a faint and shadowy type of the assertion which, since that period, you have so confidently put forth, that the South Sea expedition was an enterprise having no connexion with the protection of our commerce. Thus, speaking 
of the service generally, you remark, "that the force wanted for the protection of commerce exceeds the means of supply." Mark the words, "the force needed for the protection of commerce," from which force you cxclude the frigate and other vessels belonging to the expedition. The plan of attack had now been agreed upon, and we find the campaign thus officially opened by you. It is true, as I have abundantly shown in my second and third letters, that the memorialists, committees, members of Congress, and public press held very different language. By these, commercial considerations had been made the basis of the undertaking; and that their arguments to sustain it on this ground were invulnerable, is proved by the fact that they have never been answered. Hence the bold and audacious move to separate the expedition from all objects of immediate and practical utility, and to exaggerate its cost. 'Thus weakened, sanguine hopes were entertained of breaking it down, or, failing in that object, of at least greatly reducing its force and magnitude.

Your attacks have been bold, direct, and manly. The tenacious grasp with which you clung to office prevented that, with the late executive as well as at the present time. At one time you profess great anxiety to fit out the expedition; at another, your natural, long-cherished, deep-seated hostility breaks forth, in no very choice or set phrase, against the entire scope or plan of the enterprise. Now you speak with becoming zeal in behalf of the scientific department, and again, designate the members of the corps as oyster and clam catchers. You have done all in your power to dispirit and disgust them, by pertinaciously refusing to put them on active duty, or to allow them any compensation until the fourth of the current month, although Congress made a specific appropriation for them from the first of January last. More upon this subject presently.

We have ncxt a striking proof of your far-rcaching and sagacious forccast, which cnabled you to perceive, at the very moment the outfit was authorized by Congress, that it would be impracticable to complete it "under eight or nine months, without a se rious injury to other branches of the naval service!" Fourteen months have elapsed, and the preparations are still unfinished. The first of October is the latest period at which the vessels should depart, and I now tell you, before the face of the whole nation, 
that such has been the ruinous tendency of your clogging tardiness of action, that the squadron, even at that late date, will be compelled to proceed to sea incomplete in some of its departments, but, it is hoped, "without serious injury to other branches of the naval service!" Perchance still further delay, however, may, in your opinion, be necessary for the purpose of preventing this collision of interests!

Evidently feeling the deep necessity of strengthening your position and justifying your intended procrastination, you further state, that "the only insurmountable difficulty" in your mind was the shipment of the requisite number of men "in three or four months without interfering with arrangements already made" for sending ships to other stations. How humiliating to the pride of our country is the acknowledgment made by you, its secretary of the navy, before the commercial and naval powers of the Old World, that a small squadron, requiring but a few hundred seamen, could not be manned and sent out without deranging the great naval operations of the nation! 'This country, whose private armed ships during the revolution captured fifteen hundred sail from the enemy, which humbled the fierce corsairs of the Mediterranean, and broke the charm of British invincibility by sea ; this country, which but yesterday was bristling up to fight one of the first naval powers of the earth, ay, would have done it, and, if need be, will do it, is told by you that a sufficient number of sailors for an exploring expedition cannot be obtained without deranging your plans and weakening the efficiency of your measures for the protection of our interests in the Pacific, West Indian, and Brazilian stations! Surely no nation, however mighty, will hazard a war with the United States while you have the direction of her naval resources! It may be that the King of the French had his eye upon you when he concluded to pay the long-withheld indemnity to our citizens, and that, owing to the ingratitude so frequently ascribed to republics, you have not, as yet, received your full share of credit for the part you had in that transaction. Be assured, however, posterity will do you justice, if, indeed, you do not LEARN, while yet you may FEEL, the value set upon your official actions.

Not only does it appear from your official report that you were anxious to prepare the public mind for the delays which were to ensue, but you laboured also to convince the president that no 
agency in these delays was chargeable on you. Thus you tell him, that inasmuch as " $i t$ was his earnest wish that the intentions of Congress in authorizing the measure should be carried into effect with the least possible delay," you had not only resolved to clothe Commodore Jones with unusual powers, and to grant him "every facility" for the purpose of shipping crews, but that you had yourself "determined to make an extraordinary effort to accomplish that object." The fruits of your extra labours have been seen by the whole nation in the humiliating spectacle of what, by "extraordinary efforts," you have been able to accomplish in fourteen months, with the most ample means at your disposal, towards expediting the preparations for the voyage.

But your countrymen do not know what the "every facility" so confidently set forth in your report has been. I will tell them, and then leave them to judge whether the negative or positive quality predominates. You granted to Commodore Jones the extraordinary "facility" of shipping mariners at the regular stations opened for the general service; precisely what you allowed to others under special orders, while recruiting for the crews of vessels destined for the Pacific and Brazilian stations, and nothing more. Men at this time were commanding from $\$ 16$ to $\$ 18$ per month in the merchant service, and in the navy from $\$ 10$ to $\$ 12$ per inonth! It has been the policy of other countries to assign seamen sent on such adventures extra pay in money or clothing, often in both; while you have allowed neither, though requested to do so. Congress, at the last session, made a special grant for the increase of seamen's wages, every particle of which you have withheld from the sailors being shipped for the expedition.

You vouchsafed Commodore Jones the "facility" of detailing officers to visit New-London, New-Bedford, and the other places where it was supposed crews might be procured; but you took care to withhold from those officers money for advances, without which, it is notorious, men cannot be induced to ship, either in the merchant or naval service. I have it from the lips of an officer who visited New-London, that some fifteen or twenty prime hands, who were ready and anxious to engage, called on him at once; but not finding it convenient to make their own advances and pay their own passage to a naval rendezvous, and the officer being unprovided with funds for this purpose, he did not, as a 
matter of course, obtain one man there or elsewhere. A few months ago it was believed that a limited number of men for the expedition might be had in the district, and, as before, an officer was detached to receive proposals. He made a requisition for one thousand dollars, which was approved by the commander of the squadron. The prospect of successful recruiting in that quarter was even better than had been anticipated. Fourteen sailors waited on the appointed agent almost as soon as he had opened his office in Alexandria. They wcre told to call and sign articles on the next day. In the mean time the officer repaired to Washington for the purpose of ascertaining whether thirty dollars, the usual advance, should be charged to the men, or whether, in compliance with the special provision of Congress, that sum should be allowed as bounty. Before, however, he had time to make this inquiry of the naval department, he received from you an order forthwith to return the money placed in his hands to the treasury, as also to tell the seamen they must go down to Norfolk upon their own hook! and ship there. Of course, not one of them went.

This is but a hasty sketch of your "extraordinary efforts" to procure men; they are a fair sample of all your other "extraordinary efforts," and were, of course, attended by the same "extraordinary" success! When to these are added the enervating influence of your ungracious and reluctant action throughout; the prevalence of the belief that the feelings of the department were arrayed against the measure; the uncertainty when, if ever, the flotilla would sail, and the nonallowance of the slighest extra encouragement to the crews, it is not wonderful that the tissue of misrepresentation which mysteriously got into circulation regarding the enterprise should have obtained some credence. It was reported, I presume not to say whence such reports emanated, that the service would be one of great privation to the crews, and that all their wages would, of course, be expended in supplying their clothing for the cold and icy latitudes near the South Pole! Uniting all these circumstances to the other "facitities" you have afforded, the public mind will have little difficulty in comprehending the full force of your "insurmountable difficulties in procuring men," even when your most "extraordinary efforts" had been put forth to effect that end. Seriously, I do not hesitate to assert 
that, by a judicious application of the means within your control, the whole complement of every vessel might have been shipped in sixty, or, at most, ninety days, at any period since the passage of the bill by Congress, on the 10th of May, 1836; and that, too, without interfering with the protection of commerce, or in the slightest degree deranging the naval service of the country. In this belief I have found myself sustained by the opinions of those much more experienced in such matters than I can claim to be ; and I shrewdly suspect that you will find it something like an "insurmountable difficulty" to convince the people of this country that, with the most ample means at your command, nothing more than you have effected could be accomplished.

In speaking of the vessels, you proceed to tell the president that "the frigate and store-ship which were on the stocks when this measure was authorized, have been finished and equipped, and are now receiving their crews." What unaccountable hallucination could have possessed your mind when you wrote this sentence? Did you, in the first draught of your report, put down what ought to have been the condition of those vessels, and afterward forget to alter it? How else could you venture to tell the president, and, through him, Congress and the whole country, that the frigate was finished and equipped, and was receiving her men, when the fact was, the frigate at that time was not finished, not equipped, nor was she receiving her crew ; so far from it, she had not a bulk-head up or a yarn over the masthead, and it was not until June, six months after this official statement, that she was completed, and in a conailion to receive her complement of men!!!! 'This is another example of your "extraordinary efforts" in forwarding the outfit of the expedition, as well as of the accuracy of your official report.

"The president is further informed that you had not "yet attempted to organize the scientific corps for the expedition;" but you intimate that this duty may be performed as soon "as accommodations can be afforded them in the ressels." Strange incongruity this! In the first place, the ressels are "finished" and "recciving their crews ;" in the next you tell us that the organization of the corps is delayed until the vessels are finished and ready to receive them. 
I have pondered a good deal over this sentence, and, for the life of me, am unable to discover any necessary connexion between the organization of a corps of scientific men and the completion of the apartments intended for their reception on shipboard. I had thought these labours might progress simultaneously; but I forgot you were then making "extraordinary efforts" for the ship ment of seamen, and, with all your energies thus concentrated on a single point, might not be able to attend to other matters!

I happen to know something about the appointment of this corps. In December last, a distinguished member of Congress, while in conversation with the president, remarked that no appointments had been made by you in the civil department. The president was surprised at this intelligence, reached out his hand, and rang the bell. A messenger appeared. "Tell the secretary of the navy I wish to see him at twelve o'clock." I do not know that you obeyed this summons, nor do I pretend to say what occurred at the interview; but this I do know, that, within three days from that time, the gentlemen now composing the scientific corps received their commissions. The reluctance with which you made appointments leaves to the late executive the sole credit, so far as you are concerned, of giving to the expedition and the country an able, efficient, scientific board. I make this statement for the benefit of posterity; that, in coming time, should disputes arise as to the honoured spot or state-that gave you birth, the controversy may not be aggravated by any conflicting opinions as to the degree of credit due to you for the share you had in equipping and despatching the exploring squadron!

Do you remember that, for some time previous to the appointment of the corps, you had intermitted all action in reference to the expedition, waiting, as you said, until Congress should make further appropriations; though it can be shown, by incontestible documentary evidence, that there was, at the very time, more than one hundred thousand dollars of the past year's appropriation yet unexpended? I almost forget what the president told you when you first intimated to him that you had no funds with which to go on. He had always a most happy knack in stirring you up to "extraordinary efforts," and the only misfortune was, that severe indisposition prevented him, towards the close of the session, from 
giving to the undertaking and to you that minute and watchful attention which both so much required.

I must hurry on with my subject, and bring this letter to a close. The contest before the last Congress requires a word. I must pass over points upon which pages might be written. I cannot stop to examine your report in its financial bearing, much as it is needed, and greatly as my inclination prompts me to do so. I shall not even attempt to describe the zeal with which you warmed yourself while explaining to members of the Senate and the house the enormous demands the expedition would make on the public treasury. Your name was frequently used as authority for stating that the nation was about to squander millions upon this extravagant enterprise, which had nothing to do with the protection of commerce, and was only to explore high latitudes south!!!! The frigate, as the whole country will remember, was the special object of attack. That she was not necessary for the high southern parallels, and, ergo, not necessary for the expedition, was your argument. Officers of the navy were found to endorse your opinions. Perhaps the endorsement was mutual; at least it was so stated on the floor of Congress. Everything, for a time, promised you success, and it was asserted that you had never been known to enjoy such fine spirits; while the friends of the measure at a distance were full of despondency, being aware that the objection to the frigate was not from friendly motives towards the enterprise. There were those who believed, at the time, that the design was to cut off the frigate, and then have other commanders and a new organization; but, as I do not deal with motives, but with acts, I shall let that pass.

In the saloons of the library, in the gallery, at parties, and in messes, the merits of the contest were much discussed. Your misrepresentations of the purposes of the undertaking were fully understood by its friends in the Senate and the honse, and you were pitied for the weakness of your device. 'The members, who had honestly doubted the propricty of employing a vessel of the class alluded to, when they looked into the true objects of the voyage, yielded their assent, and voted for the measure; so that, by the time the bill of appropriations came to be read for the last time, you stood "alone in your glory," crery item in the estimate for 
the present organization and force being passed by an overwhelming majority.

The disingenuousness of the endeavour to force the friends of the measure into a false position was, as I have stated, fully appreciated ; and it was partly from compassion, and partly in consequence of a pledge you had given, that no animadversions were made upon it on the floor of Congress! 'The pledge I refer to was published by you, and over your own name, on the 19th of January last, in connexion with a correspondence you had carried on with Commodore Jones. You there distinctly declared, that while you were opposed to so large a force being sent on the expedition, "yet you had given all orders that you considered necessary for fitting it out upon the extensive scale adopted; and should continue to do so if Congress made appropriations agreeably to the estimates furnished for this object!!"

Here was a deliberate promise, a solemn pledge, given in your official character, that if Congress made provision for the outfit on its present plan, on that plan and with the required force should it be completed. Congress took you at your word by making the appropriations to the utmost farthing; and, before the nation, I hold you to the strict fulfilment of the promise you volunteered. You cannot shrink from it without covering yourself with official dishonour! How you can reconcile you course of conduct since the close of last session, with this public pledge thus staring you in the face, is a problem in the solution of which your official character is deeply concerned! Deceive not yourself; the public eye is upon you, and no sophistry can screen you from that rapidlygathering weight of your country's disapprobation which, it requires no horoscope to perceive, is destined ere long to fall upon you. To avert the blow entirely is now beyond your power, but you may weaken its force by immediate and faithful efforts in perfecting the outfit and expediting the departure of the expedition!

I shall again recur to your report.

I have the honour to be

Your obedient servant and fellow

CI'TIZEN.

New-York, July 21, 1837. 
VI.

To the Honourable Mahlon Dickerson, Secretary of the Navy. Sir,

The portion of your report to which I purpose calling your attention in this letter reads as follows: "From several learned and philosophical societies, as well as from distinguished individuals, I have received the most ample and satisfactory communications, embracing all the various subjects which it would be necessary to give in charge to the gentlemen who are to conduct the scientific researches which form the most important objects of the expedition."

With a superficial observer, this sentence is calculated to gain you credit, because it conveys something like an expression of liberality. I regret that I cannot award to you the meed of praise due to such a feeling. I cannot persuade myself that you deserve it. Connected with this subject, I do not consider that your prejudices will permit the indulgence of liberal sentiments; yet I have no idea that the sentence quoted came from your pen by accident. It is full of meaning, if not of design. Like your statement that to approach as near as possible to the South Pole was the object of the enterprise, it is, to say the least, an evasion of the true purposes designed to be accomplished. 'The inducement to make such a statement will become manifest if it be recollected that a portion of the public men in this country entertain the opinion that the government of the United States has no power under the Constitution to send out an expedition solely for scientific purposes. Stripped of its commercial character, separated from all objects of immediate and palpable utility, thrown for support upon its abstract merits as a medium of scientific research, you knew full well the quarter whence opposition to the undertaking might be anticipated, and from what quarter it would have come had you not overrated the weight of your official influence. Here, then, we have a key to the otherwise inexplicable mystery, that expressions of such sceming liberality should owe paternity to you.

No man can appreciate more fully than I do the high objects 
committed to the hands of the gentlemen composing the scientific corps. Not only may they enlarge the boundaries of science and add lustre to our national character, but, by examining and developing the resources and capacities of the countries and islands to be visited, they may even enrich the freight of commerce itself. Yet, notwithstanding all this, I have never conceived scientific research to be the main object of the expedition any more than that the attainment of high latitudes south was its principal purpose and design.

"Fourteen gentlemen," you inform us, " have been appointed to this corps, eminent for their proficiency in those sciences which are connected with natural history, or eminent in the arts connected with the subjects of natural history. No one has as yet been assigned to the departments of astronomy, geography, and hydrography. With this exception the corps is nearly complete."

If the great design of the expedition be to go as near as practicable to the South Pole, for what purpose do you send a botanist to that region where no vegetation exists? Why do you incur the expense of sending a philologist to attend to the interesting department of language where there are no inhabitants? What object is proposed by sending an entomologist in those high latitudes, when a single bug may not be found within the Antarctic circle? And wherefore should you despatch a portrait-painter to the Polar Seas, unless, indeed, you wish him to exercise his art in sketching the likenesses of seals and sea-elephants? Thus, we perceive, the two main objects of the expedition, as set forth by you, are absurdly in contradiction of each other.

I feel, however, that it is a small business to dwell on your incongruities, and have alluded to these matters only for the sake of putting you right, and of entering my protest against this further official misstatement of the leading puisposes of the enterprise. Placed on its true basis, it is defensible on the broad principle of constitutional power as well as of national policy. To provide efficient protection for our commerce, in every region with which we have commercial intercourse, and to extend it wherever it is susceptible of advantageous increase, is the bounden and acknowledged duty of government. For these noble and useful ends was the undertaking originated and authorized. Every memorial transmitted to Congress, every speech and report made by its 
members, bears directly and unequivocally upon these points, and proves that, to them, all others were subsidiary. Such, then, being the paramount objects in view, it was decided that the opportunities which would be afforded by the contemplated explorations and surveys should not be lost to the cause of science; and hence, by the direction of the executive, with the sanction of Congress, provision was made for an able scientific corps; not, I repeat, as a primary, but as a collateral department, which neither interest, the spirit of the age, nor a regard for our station among the enlightened of all nations would permit us to overlook in the general organization.

But, sir, for the still further illustration of your " extraordinary efforts" and desire "to prevent delay," I will suppose you to have been sincere in stating that the "scientific researches of these gentlemen form the leading objects of the expedition." Now I think it a fair supposition that the most important objects of any plan should receive the first attention, and, at all events, that they ought not to be the last considered. What has been the fact as regards you?

Let us see. Three months, wanting two days, after the bill had passed, you sent an agent to Europe, as you inform us in your communication to Congress of the 6th February, for the purpose of preventing "any delay that might arise from the want. of mathematical, astronomical, and plitosoplical instruments, books, maps, charts," \&c. I can hardly forbear a smile when I read your remark about precenting delay! Why were not the "fourteen gentlemen eminent for their scientific attainments" consulted before the agent departed? Or, if they were at that time unselected, it only shows that you had suffered three months to elapse without having attended to " the most important objects of the expedition!"

Your agent was furnished with the most "ample means," and to his discretion and knowledge was confided the duty of procuring all that was deerned necessary, as regarded books aild instruments, for many branches of science of which he had not the slightest knowledge. 'This gentleman, you tell us, returned on the $23 \mathrm{~d}$ of January, "having performed the duty assigned to him in the most successful manner!!" 'The agent, it would seem, entertained the same opinion you have expressed in this endorse- 
ment. With reference to the instruments brought over, in his report, which forms a supplement to your own, he discourses thus: "I believe they comprise all that can in any way be useful for scientific purposes on any expedition, and are all of them of the very best construction." 'These assertions, which Humboldt would not have ventured, are further confirmed in the next sentence, where it is said, "I trust they will be found fully adequate to the wants of the expedition."

Among these much-extolled instruments "not to be procured in the United States," I find mentioned two astronomical clocks, one journeyman's clock, two astronomical telescopes, and fortyone chronometers. I have made inquiry if any American maker of astronomical clocks had been called on by you to give a proof of his skill, but have been unable to learn that any such had, or has been, encouraged to furnish a specimen article; although it cannot be controverted that astronomical clocks, unsurpassed in accuracy, and which their manufacturers are willing to warrant equal to any which can be imported from foreign workshops, have for several years been made in this country. I am equally at a loss to know for what reason the admirable reflecting telescopes of Halcomb were wholly overlooked in your attention to the outfit of that department which embraced the "principal object" of the expedition. I have read detailed accounts of the superior excellence of these telescopes from the pens of those in whose opinions on such subjects I place the highest confidence, attesting their accuracy, portability, and the ease with which they may be managed It is the more astonishing that these matters should have been neglected by you, inasmuch as you have so long been a strenuous advocate for the patronage of domestic skill and industry! In like manner, I cannot help thinking that at least one or two of those highly-finished box chronometers made on this side of the Atlantic, which have been lauded and honoured with premiums by men who have their eyes open, and who try to keep up with the time of day, should have been ordered. It would have been a trial of skill to which our artists would have brought a full share of national pride, and the expedition being a national enterprise, they ought to have been gratified. It was due to them, and equally due to the country.

If, as you assert, the science connected with natural history 
(by which I suppose you to mean the several sciences included under the general term of natural history) constitutes the main objects of the expedition, how did it occur that your envoy failed to procure any apparatus for research in this branch, if we except a case of drawing instruments with Cameras Lucidas? 'To seven, if not more, of the fourteen gentlemen forming the scientific board, microscopes of the most approved construction, such as are made only in Europe, were, I should imagine, indispensable. But, finding no such articles on the list, I suppose it was considered that everything earthly, aerial, or aquatic too small to be seen with the naked eye was too insignificant for the notice of savans on "any expedition!"

Again : had the individual deputed, who performed his mission in " the most successful manner," looked into some of the books he brought with him, he might have learned that, in making magnetic experiments, modern observers think that a rarefied medium is highly important, and that nothing is more prejudicial to accuracy in their results than the variable influence of the atmosphere. This theory has been amply explained by philosophers in England; and long series of experiments, testing and proving its correctness, have been made in the United States. The procurement of astronomical apparatus, however, may have kept the attention of your agent so constantly fixed upon the heavens, that he unconsciously omitted to notice these trifles connected with earth!

Is it to be presumed that you consider the meteorological department well supplied with instruments without some apparatus for investigating the state of atmospheric electricity? Or, as such apparatus is not named in the list before referred to, are we to conclude that electricity does not form a subject of attention in "any expedition" fitted out under your direction, even when scientific pursuits are its "leading objects?"

'The agent very properly returns his acknowledgments to the savans abroad whom he consulted and who afforded him important assistance.

The individuals enumerated, many of them high in rank, are certainly eminent in hydrography, astronomy, natural philosophy, and as makers of philosophical instruments. This is all very well, so far as it goes; but why was not some portion of the three 
months which intervened between the passage of the bill and departure of the agent occupied in consulting the naturalists of this country? Had such a course been pursued, the labours of your envoy might have been performed much more usefully, as well as more creditably for the department and the nation. But, as this was not done, he might have advised with some of the most celebrated naturalists of Great Britain, France, and Germany, particularly with those who had accompanied former expeditions into the very seas our squadron is intended to explore. Had this plan been followed, think you they would have agreed with him in his statement, even with the high authority of your own official endorsement upon its back, that the books and instruments, as exhibited per list, comprised all that would in any way be useful in the different divisions of science?

I am not a little puzzled with this heterogeneous mélange of scientific works which have been brought hither. So far as respects the few which relate to natural history, the recent French voyages excepted, I scarcely know how an equal number of more useless volumes could have been selected. I should be glad to see you or the agent point out more than ten works, throwing aside the voyages, that any competent naturalist would have ordered. I can only name seven : Richardson's Fauna, Bennister's Entomology, Cuvier's Fishes, Landon's Encyclopedia of Plants, Genera of Recent and Fossil Shells, Yarrel's British Fishes, and Turner's Fuci. Magazines of Natural History, like the Geological and Linnæan Transactions, are not needed; though containing many important papers, the proper place for such ponderous tomes is the shelves of a library. The naturalists will require working books, manuals, and models; and these, sir, have not been provided.

The list of voyages, I am happy to find, is far more complete, although three which may be termed scientific par excellence are not included in it : viz., Pallas, Saussure, and the complete works of Humboldt. In a word, the catalogue is in itself sufficient evidence that no naturalist had any share in its adoption. Indeed, I am only in doubt whether the assortment was made by the agent, or whether he merely gave a carte blanche to a bookseller, and requested him to furnish as many cubic feet of works on natural history as he thought might be necessary for "any scientific expedition." 
To be ignorant of natural history is certainly no discredit to the gentleman you commissioned, and I have no wish to speak of his labours with disparagement; I merely regret that he should so confidently have volunteered an opinion in his official report, that he had sclected all the books and instruments which "could be in any way useful for scientific purposes on any cxpedition;" and that you, in the face of the science of the whole country, should have so complacently signified your concurrence in the statement. Your own attainments in botany, before botany became a science, should have prompted the reflection, that the field of human science is too vast to justify even one member of the corps in judging of the wants of others in distinct departmerts. 'The truth of this position is illustrated by your present defective preparations for scientific researches. After obstinately refusing to assemble the scientific corps, and assign to each member his respective duty since December last, though frequently urged to do so, you now find the "leading objects" of the enterprise almost entirely unprovided for.

On the fourth of this month you put the corps on duty, and gave them the means to prepare for the voyage. They are now, as I learn, actively employed; and, by ransacking public and private libraries, may, it is hoped, remedy the evils occasioned by your imperfect and tardy arrangements. 'Thus you find, sir, that after an interval of fifteen months, and subsequent to your official announcement that all the tools of the naturalists were provided, books have still to be imported, and orders now to be given for the construction of instruments!!! If this be good faith in the discharge of a high trust committed to your hands, then I should be glad to know what may be deemed a dereliction of duty.

In the sentence already quoted, you inform us, "no one has yet been assigned to the department of astronomy, geography, and hydrography." I have understood the selection of a competent person for this station has given you much solicitude, and that you have not even yet been successful in finding one whom you could approve. I am not sorry that in this matter you have been disappointed, because I unfeignedly believe that the appointment of an astronomer to the expedition would be an act of injustice to the naval officers employed, who, from their attainments and profession, might be relied on for the hydrographical labours to be 
performed. In a communication bearing your name, which appeared in the "Washington Globe" of the 18th January last, you hold the following language :

"From the moment this expedition was authorized by Congress, I considered that, as its dangers, fatigues, and hardships were to be borne by the officers of the navy, they ought to participate largely in its advantages and honours; and that, in all cases in which, from their literature and science, they were competent to the task of promoting the great objects of the expedition, they were to be preferred to citizens equally competent, but not subject to like responsibilities."

Although I deemed the language here used was put forth rather to foment jealousies between the officers and the naturalists, or other citizens to be employed, than as an exposition of a rule by which, from a high sense of duty, you felt constrained to act ; and while I cannot but repudiate the invidious distinctions, untrue in fact, which you have drawn between the labours that the members of the expedition, naval and civil, will respectively be required to perform, as well as the supposition that the honours which the one class might acquire could, with liberal minds, disparage the just pretensions of the other; yet, in this case, I think the navy would have some ground for complaint should the overshadowing appointment of an astronomer be made, unless practical results can be expected from his services. On this point I have doubts, and I state them for your consideration without any unbecoming confidence in my own opinion.

I should, however, be gratified to see you point out what astronomical calculations can possibly be performed which will not fall within the province of the nautical department, and which practical navigators are not most likely to make with accuracy. Have you reflected upon the means indispensable to the success of purely astronomical inquiry? Are you prepared to ask of Congress the funds for erecting an elevated stationary observatory for the permanent adjustment of costly and complicated instruments, without which an astronomer can do little or nothing? Have you taken into consideration the time which must be uninterruptedly devoted at one place to comparative observations of the celestial bodies as they move in the hemisphere? Or do you believe these observations can be prosecuted on shipboard underanged by the 
unsteady oscillating motion of the vessel? If you have not thought of these things, ay, and provided for them also, the appointment of an astronomer really appears to me little less than ridiculous, and will certainly expose you to the sneering charge of having made a pompous preparation in vain, and for an object impossible to be accomplished.

Indeed, there would be something of vain assumption and dangerous temerity in making such an appointment, even if the astronomer were to be left for several years upon a sequestered island or inland mountain to pursue his studies, with the best apparatus the world could afford, and corresponding experience and learning; for it cannot be forgotten that the most eminent living astronomer, surrounded by every facility that a nation uncalculatingly munificent in the cause of science could supply, has been devoting four or five years to the stars of the southern hemisphere, and has not yet made known any results to serve as a guide to a competitor in the same arduous field. There is not a constellation, nor is there a single star, which could be seen by this expedition in the highest southern latitudes at which it might arrive, that has not been already seen by Sir John Herschel at the Cape of Good Hope. The cost to the British government of his astronomical rescarches alone will not be less than half a million of dollars.

Sir, nothing can be done in this voyage of exploration towards mapping the heavens. Neither the means allowed nor the nature of the enterprise admit of such results, and the addition of an astronomer to the scientific corps will, in my opinion, be found, in practice, worse than useless.

The department of physical science, or natural and experimental philosophy, is already filled. 'The naval officers of the squadron are qualified to perform the hydrographical labours which appropriately belong to their profession. If these are not to be a portion of their duties, then what did you mean by alluding to the "labours, hardships, \&c.?" If they are to be so considered, should not those who render the service receive the credit? But, sir, I will go still farther, and say that the hydrographical operations can be conducted only by the naval officers. This will become apparent when you reflect that the ressels, while surveying a group of islands, will frequently be separated from each other, 
and that the positions of different members of the cluster must be defined by the officers of the respective vessels. These observations, when reported to the commander on board the frigate (which will be the depôt of all reports, naval or civil), can, by the aid of skilful draughtsmen, be reduced to regular and consecutive charts; and this will be the continual process throughout the duration of the voyage.

I must now take my leave of you for the present, and, with the addition of one more letter, may probably close altogether. Though, as I promised in the beginning, I have written you freely in these letters, you have no just cause of complaint. If, in the exposition I have given of some of your official acts, there has been some occasional appearance of severity, you know full well that they were, in comparison, but as the dewdrops of mercy to what I might have said had I gone into an examination of your doings throughout the entire history of the naval equipment of the squadron, as well as in reference to other points passed by with out remark or allusion. For the opinions advanced and facts stated I am alone and singly responsible; and if they be controverted, I hold myself at all times prepared to give my reasons for the former and my proofs of the latter.

I have the honour to be

Your obedient servant and fellow

CITIZEN.

New.York, July 28, 1837 .

\section{DEFENCE OF THE SECRETARY OF THE NAVY.}

We give place, and a prominent one, most cheerfully to the following defence of the secretary of the navy against the censures of our correspondent "Citizen." "A Friend to the Navy," maintaining the anonymous himself, must, however, allow the same privilege to his interlocutor, and will excuse us for erasing a name which he uses apparently with invidious purpose.-Editor of the New-York Times.

\section{I.}

As statements calcuated to mislead the public mind upon the subject of the South Sea exploring expedition are published in the Times under the signature of a "Citizen," you will no doubt cheerfully afford an opportunity, through the same medium, of 
correcting those statements by a narrative of facts not generally known, and which must be understood before any just opinion can be formed of the charges exhibited by this citizen against the secretary of the navy.

In consequence of a report of Lieutenant Tattnall, on his return from a cruise to the coast of Mexico in the Pioneer, one of the barks which had been constructed for the South Sea surveying and exploring expedition, that she was unfit for the service; and from reports from various quarters that the schooner Pilot, built for the same expedition, was a dull sailer, as well as an unsafe vessel, Commodore Jones was instructed to make an experimental cruise with the Pioneer and Pilot, together with the bark Consort, in order to ascertain how far those vessels might be considered as safe and proper for this expedition. After an absence of eight days Commodore Jones returned and reported favourably of the vessels, but recommended that they should be taken into drydock and examined; in consequence of which, Commodores Chauncey, Morris, Warrington, Patterson, and Wadsworth were appointed commissioners to examine into the condition of those vessels, and further to inquire whether the exploring squadron could not be reduced in number of vessels and men with advantage to the country, and without prejudice to the great objects of the expedition.

This measure has excited the rage of this "Citizen," who, in your paper of the 29th of June, and of subsequent dates, comes out in a virulent attack upon the professional character and conduct of the secretary of the navy, accusing him of a total neglect of duty in promoting the expedition, and of being governed by motives of hostility to the measure. He further accuses him of a wish to defeat the enterprise by reducing the squadron to a smaller compass, and of deceiving the commissioners as to the great objects of the expedition.

This angry "Citizen" is, no doubt, Mr. —, who has succeeded in producing an impression through the country that this is his expedition; an impression much strengthened by the publication, in October last, of his address, delivered on the $3 \mathrm{~d}$ of April of the last year in the hall of the House of Representatives before members of the two houses of Congress and others, together with letters addressed to him on the subject of this expedition, in 
which he is exceedingly magnified, especially in one from Captain T. Ap. C. Jones, since appointed commander of the squadron, who considers him the originator of the voyage; and to whom, with reference to this expedition, he addresses this language: "Who can bring so much valuable knowledge, derived from various sources, some of which you alone have been permitted to draw from as you could? I mean not to flatter when I say, not another who is a citizen of the United States." So that Commodore Jones looks up to Mr. —— as possessing so much valuable knowledge upon the subject of the exploring expedition, that he has no equal among the citizens of the United States. How far this superior knowledge is to influence Commodore Jones in directing the movements of the exploring squadron remains to be seen.

Mr. - - in his address, page seventy-four, says, "the amount of this power is a question upon which there can be but little difference of opinion among those thoroughly acquainted with the subject; the best informed are unanimous in their opinion that there should be a well-appointed frigate and five other vessels; twice that number would find enough, and more than they could do."

Here is the origin of the plan of six ships for this expedition, and one of them a frigate. Such a force as never yet went upon such an expedition.

Such was the force required by Mr. _- ; such is the force Commodore Jones now requires, and without which he considers the expedition cannot be complete or effective. But what are the words of the act authorizing the expedition?

"That the President of the United States be, and he hereby is, authorized to send out a surveying and exploring expedition to the Pacific Ocean and the South Seas, and for that purpose to employ a sloop-of-war, and to purchase or provide such other smaller vessels as may be necessary and proper to render the expedition efficient and useful," \&c.

It was to the representations of Commodore Jones that less force than one frigate of the second class, two barks, a store-ship, and a schooner, would not answer the purposes of the expedition, that President Jackson consented to the employment of so large a force. It is irle to pretend that the plan of five vessels originated 
with him. He, in fact, wanted no greater force than would meet the just views of Congress and the expectations of the public.

The secretary of the navy, in his annual report of the third of December last, makes the following statement to the president:

"When, at the commencement of the last and preceding sessions of Congress, it was recommended that a considerable addition should be made to the number of ships in commission to meet the exigences of the rapidly-increasing commerce of our country, it was perceived that, should the measurc be adopted, as it has been, by the liberal appropriations of Congress, it would be necessary to adopt, at the same time, measures for increasing the number of our seamen. The most obvious means of accomplishing this object was the one recommended, of enlisting into the service of our navy boys over the age of thirteen and under the age of eighteen, until they shall arrive at the age of twenty-one years. A bill for this purpose has been before the Senate for the two last sessions, which, it is confidently hoped, will become a law during the approaching session of Congress. In the mean time, as a larger number of seamen is required for the merchant service than usual, and as there is at present actually in the naval service of the United States one fifth more seamen than were employed three years ago, and a greater number than has been employed at any time within the last fifteen years, some difficulty must necessarily exist in recruiting seamen required for immediate service.

"The terms of service of the seamen on the Pacific and Brazilian stations are about to expire. Those on the Pacific station have been ordered home, but will not probably arrive before the middle of January next. In the mean time the North Carolina is ordered to that station, requiring immediately a large number of seamen, and Captain John B. Nicholson has been selected to sail in the razee Independence, to relieve the commander on the coast of Brazil, who, when relieved, will return with the seamen belonging to his station. The Independence will require a large number of seamen to complete her crew. Besides, it is important that each of these ships should be attended by one or two smaller vessels; but this is impracticable in the present state of the service.

"It will casily be perceived, therefore, that the force wanted for 
the protection of commerce exceeds the means of supply which this department can immediately bring into operation. When, therefore, on the 18th of May last, it was provided, by an amendment to the general naval appropriation bill, that the President of the United States should be authorized to send out a surveying and exploring expedition to the Pacific Ocean and South Seas, I considered it impracticable to fit out this expedition in a manner to meet the views of Congress under eight or nine months without a serious injury to other branches of the naval service.

"The only insurmountable difficulty, however, in my opinion, was the recruiting the requisite number of seamen in three or four months without interfering with arrangements already made for sending ships to the Pacific and Brazilian stations, and for sending an additional force to the West Indies.

"As, however, it was your earnest wish that the intentions of Congress in authorizing this measure should be carried into effect with the least possible delay, and that the expedition should be fitted out upon the extensive and liberal scale which the indications of public opinion seemed to require ; and as the officer, Captain Thomas Ap. Catesby Jones, selected for the command of the expedition, gave assurances that the difficulty of obtaining seamen could be obviated by giving him power to have them recruited under his immediate superintendence, and for this particular service, it was determined to make an extraordinary effort to accomplish these objects.

"Every facility consistent with the rules and regulations of the navy was offered to Captain Jones for recruiting seamen in the manner he proposed; and measures were immediately adopted to have one frigate of the second class, one store-ship, two barks, and one schooner, all which he considered as indispensably necessary to the success of the enterprise, prepared without delay. The frigate and store-ship, which were on the stocks when this measure was adopted, have been furnished and equipped, and are now receiving their crews; and the other three vessels have been entirely built and equipped for sea. The whole have been finished in the most substantial manner, and adapted to the particular service for which they are destined. These vessels will sail to Norfolk to complete their crews, take in their stores, and to await further orders. 
"To prevent any delay that might arise from the want of mathematical, astronomical, and philosophical instruments, books, maps, charts, \&c., required for the expedition, Lieutenant Wilkes, of the navy, was sent to Europe, and sailed from New-York on the 8th of August last, to make the necessary purchases; in which he has been successful as to the greater part of the articles wanted. For some instruments, however, he has been under the necessity of waiting until they can be manufactured. His return is expected about the middle of this month.

"It is believed that every proper exertion has been made to recruit men for this service, but without the anticipated success; no more than about two hundred, according to the returns received, being as yet recruited; and, as Captain Jones requires five hundred and eighteen petty officers, seamen, ordinary seamen, boys, and marines, together with eighty-five commissioned and warrant officers, for his squadron, it is evident that a considerable time must yet elapse before the expedition can be ready for sea.

" Recruiting seamen for a particular service may be attended with great inconvenience, and should not be adopted but upon the most urgent occasions, such as that of the exploring expedition was conceived to be. If the exigences of the government should require of such recruits service different from that for which they were enlisted, discontent, and even mutiny may be apprehended. Besides, this mode of recruiting cannot but interfere with the recruiting for the general service; and, in the present case, the order to recruit for the exploring expedition has made it necessary to adopt the same mode of recruiting for the crews of the vessels about to sail for the Pacific and Brazilian stations.

"Recruiting for three distinct objects of service at the same time, while the usual recruiting for the general service is continued, cannot but retard the whole, and compel us to keep in receiving vessels a much larger number of recruits, constantly disposed to desert, than would be required, if recruited, for the general service alone.

"Although the number of recruits is small for any one of these objects, yet, in the aggregate, the number is quite as great as should be expected, when we consider the unusually great number of seamen now in the naval service of the United States, and the great demand for them in the merchant service. 
"Although the return of the public vessels now ordered to the United States will, to a considerable extent, furnish men for future service, yet sending out so large a force as that required for the exploring expedition, to be detained for the term of three years, cannot but be felt as a serious inconvenience in fitting out the number of vessels wanted for the immediate protection of commerce."

From this it appears that Commodore Jones, appointed to the command of the exploring squadron, deemed one frigate of the second class, one store-ship, two barks, and one schooner, as indispensably necessary to the success of the enterprise; on which measures were immediately adopted to have these vessels prepared without delay. This report the president laid before Congress.

On the sixth of February last the secretary of the navy made a report to the president, in which he states that,

"In answer to the resolution of the House of Representatives calling for information as to the progress which has been made in the arrangements for the surveying and exploring expedition authorized at the last session of Congress, and of the objects and measures to which said expedition is to be devoted, \&c., and which, on the fourth instant, you referred to this department, I have the honour to state that, in my annual report of the third of December last, I gave a brief outline of the progress that had been made in the arrangements for this expedition up to that time; which may be found in document number two of the House of Representatives, pages 444,5 , and 6 , together with a report of the commissioners of the navy of the measures which had been taken to carry the same into effect, and an estimate of the amount that will be required for the support of the frigate Macedonian, the store-ship Relief, the two barks Pioneer and Consort, and the schooner Pilot, to be employed on this expedition for one year, which report and estimate may be found in pages 484 and 485 of the same document.

"The resolution referred to requires further information than was contained in my report, as also what progress has since been made in these arrangements.

"The great objects of this expedition, as understood by this department, are to explore the seas of the Southern Hemisphere. 
more particularly in the high latitudes, and in the regions as near to the pole as may be approached without danger; to make in these regions thus to be explored all practicable surveys and observations, with accurate descriptions of the same, connected with geography or hydrography, by which the interests of commerce and navigation may be promoted; and to make all such researches as the opportunities of the expedition will afford, to advance all branches of science which have attracted the attention of the governments of Europe in fitling out vessels for survey and discovery.

"In the beginning of July last your wishes to carry into effect, to their full extent, the views of Congress in authorizing this ex. pedition, induced you to make it a subject of immediate consideration and action.

"Captain Thomas Ap. C. Jones was selected to take command of the expedition. 'The offer to take this command was made to him, and accepted on his part.

"The confidence placed in this officer, which led to his selection for this important command, seemed to require that he should be consulted as to the number and size of the vessels, and of the vessels, and of the amount of force, of which his squadron was to be held in a high degree responsible for the success of the expedition.

"He was of opinion that one frigate of the second class, one store-ship, two barks, and one schooner, were indispensably necessary to the success of this object.

"In accordance with this opinion, the most prompt measures were adopted for preparing and fitting for sea the vessels required.

"Captain Jones was instructed to visit the different navy yards in which the vesscls for his squadron were to be built and prepared, and to make such suggestions as he should think proper as to the manner of building and preparing the same, and to which the commandants of the yards were directed to conform.

"As, at the lime of passing the act authorizing this expedition, it was necessary to take immediate measures for relieving our squadrons on the Pacific and Brazilian stations, as well as to send to the Gulf of Mexico a considerable force in addition to that previously sent there, it was evident that the requisite number of seamen for this expedition could not be recruited without ex- 
traordinary exertions. Measures were therefore taken to recruit men for this particular service under the direction and superintendence of Captain Jones, and Lieutenants Tatnall, R. R. Pinckham, Purviance, and H. W. Morris were ordered to report to him for service in recruiting for this expedition; and others were subsequently ordered for the same service. It is believed that due diligence has been exercised by the officers on this service to recruit the requisite number of men, but without the success that had been anticipated. This is partly owing to the necessity of recruiting at the same time for the Pacific, Brazilian, and West India stations; and of the five hundred and eighteen seamen, ordinary seamen, landsmen, and boys required for the several vessels of the exploring squadron, no more than two hundred and forty-eight have been yet recruited, as by the last returns.

"'The difficulties, however, which have retarded the recruiting for this expedition are nearly obviated; and it is confidently hoped that in a short time there will be sufficient numbers recruited to complete the crews of all the vessels of the squadron."

This report was transmitted to the House of Representatives with an expression of a wish, on the part of the president, that all facilities might be given to the exploring expedition that Congress could bestow and the honour of the nation demand.

If the objects of the expedition indispensably required the employment of five, or even six ships, and the honour of the nation demanded the employment of so large a force, then was President Jackson in favour of it, not otherwise.

Congress in February last made appropriations under which five ships might be employed on this expedition, but did not require that so large a force should be employed unless, agreeably to the condition of the act authorizing the measure, such force should be necessary and proper to render the expedition efficient and useful. The appropriations do not require the needless expenditure of money; nor do they in the slightest degree interfere with the propriety of reducing this force, if the interest of the country should require it.

The character of the expedition has not been changed; it was originally a surveying and exploring expedition, and is so still.

By the reports cited it will appear that there was extreme difficulty in extending to our commerce all the protection due to it, 
and which the interest as well as the honour of the country demanded should be attended to in preference to the exploring expedition.

In the years 1836 and 1837 more has been required and more has been done for the protection of commerce than in any other two years since the late war.

Before the required number of seamen could be recruited for the exploring expedition, it was discovered that the bark Pioneer was unfit for the service for which she was intended; and the bark Consort and the schooner Pilot were considered as less fit for the service than the Pioneer; at least, such was the prevailing opinion among the officers of the navy.

The secretary of the navy is not to be charged for the want of success in recruiting seamen for the expedition; and surely he is not to be held responsible for the condition in which the vessels built for the expedition are found. But he will be held responsible to the country if he suffers these vessels to go on the expedition without a thorough examination. For such an examination appropriate measures were adopted. Delay must ensue; but this is unavoidable. Delay in our ports is to be preferred to disaster abroad.

The great offence on the part of the secretary is, that the commissioners have been instructed to inquire whether the exploring squadron may not be reduced in number of vessels and men with advantage to the country and without prejudice to the great objects of the expedition.

If such a reduction can, it is highly expedient that it should take place in the present situation of the country. 'The exigences of our commerce are such as to render it highly improper to send out a larger force for the purpose of survey and exploration than may be absolutely wanted for those particular objects. Procuring the large amount of specie that will be wanted for this entire squadron, especially if it is to be increased by the addition of another ship, now required by Commodore Jones, will create much embarrassment. This difficulty was not foreseen at the last session of Congress; and the circumstance, which is now apparent, that we shall lack revenue for the exigences of government in the coming year, would justify the inquiry if there might not 
be some reduction in the million and a half of dollars which this exploring expedition is about to cost us.

The "Citizen" accuses the secretary of the navy of deceiving the commissioners as to the objects of the expedition.

The objects stated to the commissioners are the same as were stated in the report of the 6th February, laid before the House of Representatives, and not disapproved of by them.

'The commissioners were informed that the cruise of the exploring expedition would continue three years; that its objects would be chiefly to explore the oceans and seas of the Southern Hemisphere, more particularly in high latitudes, and in regions as near the pole as may be approached without danger.

That some portions of the Pacific north of the equator might probably be visited by the squadron, or some part of it.

That the scientific corps to be attached to this expedition would consist of from fourteen to eighteen individuals, whose duty it would be to make in the regions to be explored all practicable surveys and observations of the same, with such accurate descriptions and drawings as may be most useful for the purposes of navigation and commerce; and to make such researches as the opportunities of the expedition would afford in all branches of science, which have attracted the attention of the governments of Europe in fitting out expeditions of a like character with this.

Surely this embraces enough for the consideration of the commissioners, whose professional experience enables them to determine with accuracy what is meant by the terms surveying and exploring expedition.

The duties to be performed under the commander of the squadron will be pointed out to him in detail in his final instructions, but need not be communicated to the commissioners.

The "Citizen" thinks the vessels of this squadron should have been sent out long since, fit or unfit for the service, for he says the expedition should "now be doubling the cape, and every one engaged in the enterprise full of hopes of having immediate opportunities of fulfilling their country's expectations."

Now, although it is very pleasant weather here in June and July, it is quite the reverse at Cape Horn; it is winter there, and the officers of the navy would prefer a different season for doubling the cape, if a "Citizen" will permit them. 
How much time will be required for making the alterations which may be found necessary in these vessels is uncertain; probably not more than a few weeks. 'The requisite number of seamen are recruited; and unless there should be difficulty in commanding the service of officers upon this expedition, it may leave the United States in time for doubling Cape Horn at the most favourable season of the year.

\section{A FRIEND TO THE NAVY.}

July $31,1837$.

\section{II.}

The facts stated in my former number show that the difficulty and delay of recruiting seamen for the exploring expedition were not to be attributed to the secretary of the navy, nor was he to be charged with the delay occasioned by the necessity of having a thorough examination of the two barks and schooner built expressly for the expedition. But the "Citizen" accuses him of being opposed to the bill authorizing the expedition.

There has probably been no secretary of the navy who would not have gladly engaged in sending ont an exploring expedition, if it could be done in accordance with his own views, and without embarrassing him in the performance of other official duties of more immediate importance and of higher responsibility.

In 1836 the duties to be performed by the navy for the protection of commerce, and which the honour of the nation required should be attended to in preference to all others, exceeded the means of the navy department, as appears by the published extracts from the secretary's reports; and the imposition of new duties in fitting out an exploring expedition could not fail to increase the difficulties of his situation, withont relieving him of responsibilities, which effect they have had, to the most serious injury of the service. It is not strange that the secretary should feel opposed to the imposition of new duties at a time of so much difficulty; nor is it strange that he should be opposed to the manner in which the provision for the exploring expedition was introduced into the general appropriation bills for the navy. 
Early in the session this bill had been sent from the House of Representatives to the Senate; there an amendment was proposed authorizing this expedition; and there it remained, loaded with this rider, until nearly the time of passing the bill on the 18th of May, 1836, more than five months after the commencement of the session, and when the naval service was greatly embarrassed for want of the appropriations; for not a dollar had been appropriated for this service from the beginning of the session until this time.

Much delay has taken place in consequence of the condition of these vessels; but all difficulties as to the vessels can be removed in time for sending out the expedition so as to double Cape Horn at the most favourable season of the year. The two barks can be so altered as to make them fit for this service, and the schooner, should the officers place no confidence in her, can be left, and another substituted; and even the additional ship which Commodore Jones now requires can be procured, should it be deemed necessary.

There is, however, a serious difficulty in the case not mentioned by the "Citizen," but produced in no small degree by himself, which requires examination: that is, the general disinclination, on the part of the officers of the navy, to engage in this expedition, which arises, in part, from an impression that this is considered the expedition of an individual rather than of the country; and from the circumstance that two meritorious and scientific officers were excluded from the command of two of the smaller vessels of the squadron.

The officers of the navy are probably afraid that, from the published opinions of various distinguished gentlemen of the transcendent claims of $\mathrm{Mr}$. - that he will have an undue influence in the movements of the squadron, as that of doubling Cape Horn in June and July; approaching too nearly to the verge of this said opening of sixteen degrees around the pole, or some other movements to test the truth of his strange theories.

These fears have not been removed by the displays of scierice in Mr. —-'s published address, in which he informs the world that " the great improvements in mathematical instruments have made the path of the mariner in the darkest night, and amid rush- 
ing tempests, as easy to be attained and followed as the paved streets of a populous city." Page 16.

That "in every part of the earth's circumference where a keel can go our countrymen are to be found gleaning the molluscous treasures from the coral reefs in equatorial climes," \&c. P. 24.

That "what men can do they (American seamen) have always felt ready to attempt; what man has done it is their character to feel able to do; whether it be to grapple with an enemy on the deep, or to pursue the gigantic game under the burning line with an intelligence and ardour that ensure success, or, pushing their adventurous barks into the high southern latitudes, to circle the globe within the antarctic circle, and attain the pole itself; yea, to cast anchor on that point where all the meridians terminate, where our eagle and star-spangled banner may be unfurled and planted, and left to wave on the axis of the earth itself !" P.99.

This address contains many other passages equally delectable and instructive.

It is certainly news to the naval officers that the improvements in mathematical instruments have made the path of the mariner in the darkest night, and amid rushing tempests, as easy to be attained and followed as a paved street in a populous city. This would be extremely consoling to them could they believe it. But, as this information is so far in advance of anything ever said or thought of by Laplace or Bowditch, the officers must be excused for believing that Mr. was practising upon the credulity of his audience, or that he was totally ignorant of the subject upon which he was speaking. Our officers will also be surprised to hear that in every part of the earth's circumference where a keel can go our countrymen are to be found gleaning molluscous treasures from the coral reefs in equatorial climes. As our keels can go into Hudson's Bay and Behring's Straits, our countrymen must be there, according to Mr. — 's information, gleaning molluscous treasures-and from coral reefs too-and those reefs of equatorial climes, whether abounding in molluscous treasures or not.

From Mr. - 's flourish of circling the globe within the antarctic circle, yea, of casting anchor on the point where all the meridians terminate, and of leaving the star-spangled banner to wave on the axis of the earth itself, which he, no doubt, considers 
a huge flagstaff, it would appear that he has renounced his former theory of a great opening of sixteen degrees at the pole; that is, if he is in earnest in his plan of leaving the American flag to wave on the axis of the earth, of which there is some doubt.

The extravagances of Mr. - have created many difficulties in fitting out this expedition; yet all these can be obviated if he will be content with the distinguished and lucrative situation assigned him in the same, and not ostentatiously and offensively attempt the direction of the enterprise, to the great annoyance of officers who have entered the navy with hopes of distinguishing themselves in battle for their country, and who have no ambition to engage in the service now proposed for them under his auspices.

Respect is due to the pride and feelings of gallant officers of whom unusual, unexpected, and subordinate duties are required.

On this expedition much time must be spent in collecting and examining subjects of natural history; much time must be spent in tracing the shores and dredging in the deep seas in search of new and undescribed animals. By these labours great additions will be made to science highly interesting to the gentlemen engaged in making discoveries, and highly honourable to the country, but somewhat irksome to officers performing a subordinate part in these operations, and who aspire to service more properly belonging to their professional duties.

To such labours and discoveries no more force should be applied than what is absolutely necessary.

In other countries exploring expeditions are fitted out, but generally on a small scale.

Among the most splendid exploring voyages of modern times is that of the Astrolabe, a corvette of eighteen guns and a crew of eighty men.

Two ships would be quite enough for the purposes of survey and exploration on this South Sea expedition, and an additional vessel for the search of wrecked mariners.

Five ships and six hundred men cannot be wanted for any purpose whatever necessarily connected with the expedition, not even for the purpose of gleaning molluscous treasures from coral reefs, in which it seems our countrymen are engaged wherever a keel can go. 
The country wishes to see an exploring expedition fitted and sent out commensurate with the proper objects of such an expedition, and no greater. It does not wish to pay a million and a half of dollars for what, at most, should cost half a million; and, especially, it does not wish to send out the specie that will be required for the expedition on the magnificent scheme of Mr. at a time like this, when the specie wanted for the indispensable exigences of the navy can with the greatest difficulty be procured.

If the secretary of the navy had thought himself authorized to send out the exploring squadron in preference to providing for the Pacific, Brazilian, and West India stations, which he certainly did not, yet he could not have sent out the number of ships required by Mr. — as they are not prepared for service, nor will they be for some weeks to come; and yet, on the part of the secretary, there has not been a moment's delay in having those vessels prepared for sea. The delay, if any, is to be attributed to some other quarter.

\section{A FRIEND TO THE NAVY.}

August 1, 1837

CITIZEN'S LETTERS.

VII.

To the Honourable Mahlon Dickerson, Secretary of the Navy.

Sir,

The sagacious Prince of Idumea, the patient Job, once said, "Oh! that mine enemy had written a book," the true interpretation of which is, $\mathrm{Oh}$ ! that mine antagonist would put his arguments in writing; he has, thank God, done it in this case. Yes, sir, you have at length been aroused. 'The voice of ptiblic censure has reached you, while but a single individual has becn found to file for you a plea of not guilty before the bar of public opinion. 'The Times of 31st July and 1st of August contains his productions over the signature of "A Friend to the Navy ;" which, for the sake of consistency, and in order to leave a more faithful record for the 
future, had more properly been simply "your friend" or "an enemy to the navy."

When I cast my eyes cursorily, for the first time, over these "delectable" productions, I could not help feeling deep commiseration for you, that so long a life of patriotic, liberal, and enlightened services to your country-of which, unfortunately, but few records have been preserved-and especially the several years you have occupied-I cannot say filled-the chair of your official predecessors, watching with more than paternal solicitude over the naval concerns of the country, infusing into all their branches a due proportion of your own energy and decision, and inspiring the officers by your own illustrious example with a liberal and harmonious spirit of action; I say, remembering all these things, I could not avoid feeling commiseration that no abler pen had been employed in the doubtful task of rescuing your official character from obloquy. I could not but ask myself, where is the chivalry of the navy, that it does not rally round its great head and pattern in this his hour of need?

In looking over, for the second time, what "A Friend to the Navy" had put forth in your defence, I must own I had some misgivings as to who that "friend" might be. I began strongly to suspect that he was no friend, but an enemy, to you as well as to the navy, who had assumed the mask of friendship for the malignant purpose of rendering you ridiculous in the eyes of your countrymen by the very puerile, evasive, and disconnected style he had adopted in attempting to sustain you. This impression was further strengthened by the fact, apparent to every reader of lis articles, that all the charges I have preferred against you were, substantially, admitted; whilc the whole scope and tenour of the language used manifested more decided hostility to the expedition than had been openly avowed in any previous communication of your own. I intend to have an extra number of these articles struck off, as, whether prepared by a friend or a foe, they serve to confirm everything I have said in my letters with regard to you, and such were my second impressions; they did not, however, last long.

When I began to compare the effusions of "A Friend to the Navy" with the extracts from your official reports, inserted by him in the way of filling up your defence, and noticed their striking 
similitude in style and language, the familiarity with which reference was made to reports and instructions not yet made public, together with certain allusions to doings and intentions of the department which could be known to yourself alone, I could not help imbibing the belief, here quite current, that the author or "Friend to the Navy" was a personage high in place, who spoke as one having authority. This circumstance, I thought, might elevate to the dignity of deserving a notice compositions which, without such adventitious aid, were absolutely beneath criticism, and could only be attributed to a high source by supposing the incumbent utterly incompetent to discharge the important duties of his station.

This is a melancholy reflection, and no less melancholy is the task of noticing at all the defence of such a champion of the honourable secretary of the navy.

"A narrative of facts not generally known" is promised in the beginning by your defender. Has any narrative been given, sir, which impairs the force of the charges I have brought against you; charges of which the justice is felt and acknowledged by all who have had anything to do with your department or an opportunity of seeing your tardy, insincere, and reluctant action in fitting out the expedition?

Why was your defence, in point of time, commenced from the late period when Lieutenant Tatnall returned in the Pioneer from the coast of Mexico, ten months after the passage of the bill, and more than eighteen months after you had set your mighty energies to work for the purpose of preventing the expedition being authorized? What was your official action in the premises during that period? Why has not this point been met and explained away? Sir, do you suppose the community blind? Do you flatter yourself that you can roll back, even assisted by the puissant arm of "A Friend to the Navy," the current of public reprehension which your official career has called down upon you? Make the effort, sir, and prescrve yourself if you can.

'The Pionecr was reported unfit for the expedition, and Commodore Jones, at his own request, was directed to make an experimental cruise. That cruise was made, and its result inspired the commander with confidence in his vessels, or, as you say, he "reported favourably of the vessels." I have seen a letter written 
by you after receiving that report, wherein you write, " The report of Commodore Jones is extremely discouraging." Put this and that together; but let it pass.

It was recommended that the vessels go into drydock. This was a godsend to you. The occasion was seized upon, and made a pretext for the appointment of a commission extraordinary, although Commodore Jones had returned and "reported favourably." How did you speak of this report when first received? Did you then say it was favourable? I apprehend not; at any rate, accident has placed before me a letter, to which I have already referred, in which you speak of this same report as "extremely discouraging!!"

Of this board: the obvious motive for its appointment; the extraordinary character of the instructions you gave for the guidance of its action; the consequent duties you expected it to perform, are subjects which have all been sufficiently discussed in my preceding letters, and demand but a short incidental notice here. Not to look into the condition of the vessels only was the commission opened, but to assume, to a certain degree, legislative power ; to undo what Congress had directed should be done, and which you, with all your hostility to the expedition, had not the moral courage to contravene; in short, to reduce the force authorized. Why was not Commodore Jones appointed a member of the board? Was he not deeply interested in the examinations and decisions to be made? Were you apprehensive that he would expose the insidious character of your instructions, by showing the members of your commission that you had now assumed new ground and adopted opinions directly at variance with those you had previously professed to entertain? Had you forgotten, or was it inconvenient to remember, what you had said of that officer in your famous report of April 6,1837? If you had foreseen your present predicament, you would never have penned the following sentence: "The confidence placed in this officer (Commodore Jones), which led to his selection for this important command, seemed to require that he should be consulted as to the number and size of the vessels, and the amount of force of which his squadron was to consist, as he was to be held in a high degree responsible for the success of the expedition." A liberal and just sentence this, but only written for effect, not for action, as your 
recent course has abundantly proved. You acknowledge that the commander, inasmuch as he was to be held in a high degree responsible for the success of the expedition, ought to be consulted on the force to be employed, and afterward to exclude him from a board instructed to decide on this very point. Do you imagine, sir, this shallow device was not fully understood ; or do you suppose there is a man of intelligence in the country, who has paid the slightest attention to the subject, who believes that an honest solicitude for the success of the enterprise was your motive for convening this board, under the instructions it received? Did you not expect, sir, that it would report as a packed jury would decide; and have you not been greviously disappointed by the recent decision against you? Can you deny it? Yes, you may, probably will do so; but you cannot conceal, even while making the denial, the keen and bitter disappointment rankling within that this, your great last move, has been defeated, leaving you once more naked, alone, and unsupported in your plans to destroy the efficiency of the expedition; or at least proving that, if you had supporters, they did not choose to compromise themselves by publicly agreeing with you, under circumstances so well calculated to call in question their patriotism and sense of public duty. Thus discomfited, worsted, and overruled in all your machinations; required by the present as well as by the late executive to go on and do your duty, and that speedily, you have at last, with something like an "extraordinary effort," put the preparations in a state of progress. The falling off in the revenue, with the $\mathrm{im}$ mense and ruinous amount of specie which the squadron will require, are points from which you still entertain some lingering hopes. I will examine the piteous wailings of "A Friend to the Navy," and pledge myself to show that he is as uninformed upon the latter subject as you have chosen to remain of the true purposes of the expedition. For what end is a heavy amount of specic needed by the squadron? If it touch at Lima or Valparaiso, we have naval stores and a navy agent at both those places; and there bills on the United States command a premium. In the purchase of refreshments at most of the islands specie is unnecessary, inasmuch as all the provisions furnished by the natives are to be procured in exchange for our domestic manufactures (implements of industry, \&c.), which will leave the money at 
home, instead of expending it in foreign ports, as is done by the rest of our squadrons. Sir, I do not hesitate to say that the specie requisite for this expedition will not amount to one third the sum required for a similar force on any of the regular foreign stations; and, moreover, if the purpose of the expedition be to reach the South Pole, or near it, what, in the name of common sense, would be the demands for specie there? 'To bring such an argument against the enterprise shows that " $\mathrm{A}$ Friend to the Navy" must have felt himself at a nonplus in seeking feasible apologies for your conduct.

Let me see, sir, what is the next point to be noticed? The law authorizing the expedition. This must be examined, as "A Friend to the Navy" has been wildly extravagant in his interpretation of its meaning, and has made an effort to shield your late illegal proceedings by his palpable misconstructions. The frequency with which he refers to this law shows that he relies mainly on its authority in attempting your vindication. I own that on this point his arguments are by far more specious than on any other connected with the subject; nevertheless, his conclusions are unsound, and in no respect warranted by the act from which they are deduced. 'The words of the law are :

"That the President of the United States be, and he hereby is, authorized to send out a surveying and exploring expedition to the Pacific Ocean and South Seas, and for that purpose to employ a sloop-of-war, and to purchase or provide such other smaller vessels as may be necessary and proper to render the expedition efficient and useful," \&c., \&c.

Now it is important to bear in mind that the committee on naval affairs in the Senate drew up a very able report, setting forth the great objects of the expedition, to which was appended the bill from whence the above extract is made, as the authority under which the executive was to act in carrying the will of Congress into effect. When did this bill become a law? At the first session of the last Congress. What was the language of the report in reference to this law? Jet us see.

"The committee think it ('the expedition') ought to consist of two vessels of about two hundred tons burden for exploration, one of about one hundred tons as a tender, and those accompanied 
by a sloop-of-war to afford protection, and to secure peaceful and friendly relations with the inhabitants of the islands.

"But the committee do not think it necessary to prescribe in the law which may be passed either the dimensions or character of the vessels, or the number and qualifications of the persons who shall be employed; nor can they exhibit by precise estimates the exact sum which shall be expended. 'These are matters which must, to some extent, be left to the discretion of the executive, who will carry the will of Congress into execution."

In this clear and explicit form did the subject come before the executive, to whom a discretionary power was intentionally and very properly granted. Had there been any doubt as to the intent of the law, the report of the committee afforded an ample interpretation.

That report speaks of the smaller vessels for "exploration, and a sloop-of-war as protection, and to secure peaceful and friendly relations with the inhabitants of the islands," but you contend, indeed, I have heard you avow, that you would not look at the reports or to memorials as setting forth the intentions of Congress and the objects of the expedition.

You sometimes, however, do things which you have previously declared you would not do. For the purposes of protection the president had authority to order a frigate on what service he chose, without the sanction of this bill. Will you, or "A Friend to the Navy," have the goodness to put into print the statement, that the president, when he gave directions for the Macedonian to be prepared for the expedition, did so with the view that she should only go near the South Pole, and that the protection and security of our commercial interests in the Pacific had nothing to do with his decision. No boxing the compass, "Mr. Friend to the Navy ;" come to the point at once.

"But," says "A Friend to the Navy," "it is idle to suppose that the plan of five vessels originated with him" (the late president); "he, in fact, wanted no greater force than would meet the just views of Congress and the expectations of the public." Very true, most wise and learned judge ; and I should like to be informed who ever desired a greater force than would " meet the just views of Congress and the expectations of the public ?" Here I make another point, and ask for an explicit answer. 
Again: does "A Friend to the Navy" wish to be understood as saying that the force which the president did sanction was too large to " meet the just views of Congress?" In replying to this query let there be no evasion. Answer; did the late executive authorize a force too large for the purposes of the expedition as set forth in the proceedings of Congress? I wish to see if " $\mathrm{A}$ Friend to the Navy" will dare to do directly what by implication he has already done, viz., censure an official act of the late head of the nation.

Was not Congress in session? Had not the president frequent interchanges of sentiment with the prominent friends of the measure in that body? Was not the subject of the force proper to be employed fairly discussed and fully considered. Did not the executive hear the pros and cons? Were not you active at your usual employment of cutting down and finding fault? Yes, sir, such was the position of affairs, and the adoption of the frigate was not at the suggestion of Mr. - nor to gratify the pride of Commodore Jones, as has been so often and so invidiously insinuated, but for reasons now understood by the whole community, and previously sanctioned by the friends of the undertaking at the close of the first session of the last Congress. 'The force and organization approved by the executive, including the substitution of the frigate for a sloop-of-war, were not considered on a scale too extensive for carrying out "the just views of Congress and the expectations of the public." If these matters were not known to you, sir, they are no less true on that account; they must be fresh in the recollection of many members to whom I have alluded, the extraordinary opposition you manifested towards the expedition being often the theme of pleasantry among them !

Thus did the affair stand at the termination of the first session of the recent Congress. Let us inquire how it stood at the commencement, as well as at the close, of the last session?

In the exercise of that discretion alike belonging to his station and conceded by the law, the president recommended a frigate to be substituted for a sloop-of-war.

Accordingly, the estimates were sent in for the frigate and other smaller vessels. The question was thus brought fairly before Congress, and was as distinctly understood. You laboured zealously to prevent the adoption of a larger vessel to supersede 
the sloop-of-war. On all occasions, both in season and out of season, your voice was heard upon this subject, and it was your sedulous endeavour to have the estimates for the frigate stricken out, which the president had ordered you to present to Congress. What was the result? Why, sir, the national legislature approved what the executive, in the exercise of his best judgment, had done; the frigate was provided for, and, by that act, took the place occupied by the sloop in the law of the preceding session. All discretionary power here properly terminated; precisely as all executive discretion in the modification of a treaty ceases when it has been ratified by the Senate. I appeal not to you, sir, but I do appeal to every man of intelligence, if this be not the only true, the only fair exposition of which the case will admit. What, then, can be thought of all the special pleadings of " $\mathrm{A}$ Friend to the Navy," when he claims for you the right, by the agency of a naval board, to lay Vandal hands upon the frigate; an assumption of authority about as defensible as would be the cutting off of one or all of the smaller vessels, because, forsooth, something about them might not suit you; when, the truth is, nothing about this expedition ever did suit you or ever vill.

I am at a loss to know, perhaps you can tell, what "A Friend to the Navy" means by stating that "Congress, in February last, made appropriations under which five ships might be employed on this expedition, but did not require that so large a force should be employed, unless, agreeably to the act authorizing the measure, such force should be necessary and proper to render the expedition efficiently useful." And pray, sir, where do you find this power of limitation confided to the secretary of the navy? Whence is the inference, and where the authority, sir, that Congress made an appropriation that might be used, and, at the same time, did not require it to be usecl. I ask for the proof that any portion of this expedition has been conditionally sanctioned, and I know that I ask in vain, notwithstanding the boldness with which "A Friend of the Navy" has hazarded the assertion. Sir, you have no authority for your late efforts to break up the expedition by reducing its force, and sophistry cannot screen you from the public censure which that act alone has called down upon you. Allow me, sir, to illustrate this point by what might be deemed a parallel case, and one in which I think you would adopt pre- 
cisely my views with reference to the point at issue. The heads of departments at Washington receive, as compensation for their services, six thousand dollars per annum each. Suppose, at the commencement of the next session, when the bill making provision for the civil list is presented, that under the head of "for the secretary of the navy" twelve thousand dollars should be inserted. The subject comes before the house. Some member inquires, How is this? Here is an appropriation of twelve thousand dollars where six thousand stood before; a frigate in place of a sloop-of-war; I go against that, Mr. Speaker. On the other hand, it is urged that, in consideration of the " extraordinary efforts" of the secretary of the navy in fitting out the expedition, and of the extra and unpleasant duties imposed upon him by the measure, as also to compensate him, in some slight degree, for the loss of official character he has sustained, this additional remuneration had been proposed. Finally, the claim is entertained and sanctioned by Congress, though not until some unsuccessful motions have been made to strike out the allowance altogether. Now, under these circumstances, does any man doubt that you would be entitled to the twelve thousand, or could any executive officer withhold the same without violation of law? What would be thought of the United States treasurer, should he assemble a board of auditors to inquire if the appropriation made for the honourable secretary of the navy could not be reduced without preiudice to the public service?

1 have now done with the law authorizing the expedition, and cheerfully leave it for the public to decide whether I have or have not shown that, under that authority, you can have no legal plea for your late proceedings. I have said more on this head than I originally intended, because it was evidently the point of all others upon which "A Friend to the Navy," in his first number, relied with most confidence in making out your defence.

Perhaps the most curious part of that defence is the positive tone in which it is still denied that Congress or the executive regarded the expedition as a means of protection to our commerce. I have already reviewed this point in my second and third letters, and, by the production of evidence from memorials, reports, speeches, \&c., have so completely removed every loop upon which a doubt could be hung, that nothing but an unaccountable 
perversity of temper in "A Friend to the Navy" could have induced him to reassert a proposition so absurd. Where, sir, permit me to ask, are the exigences of our commerce so urgent as in the very regions to be visited by the expedition; in these regions it requires protection, and, your disingenuous pertinacity to the contrary notwithstanding, will receive it. Do you suppose the president will allow you to compromise the character of the country by venting your personal spleen in your final instructions, and, through them, directing the expedition to explore seas and perform labours different from those intended by Congress, by the executive, and by the nation?

Will you learn nothing from experience? Have you not even yet suffered sufficient defeats to teach you how much you have overrated your official influence, and that the country will not permit you to trample upon its laws, or trust its honour or its interests entirely in your hands, while settling the character of a great national enterprise? Yes, sir, your final instructions will, I venture to predict, be examined by the president before you are allowed to despatch the squadron; and such a scrutiny will be a sufficient guarantee that the true purposes of the undertaking are fully and fairly detailed. I know that you are committed upon this head, and perhaps you feel that the only chance you have of escape is to brave it out. This is wrong. When the plan of denying to the expedition all purposes of a commercial nature was agreed upon, the hope of success was so feasible, that one of your ardent temperament was readily seduced into the measure without being sufficiently wary in calculating the chances of discomfiture. Be assured, however, it is now the best policy to retreat with what grace you may, as retreat you ultimately must, from such an untenable position; a position assumed, as you well know, for the sole intent of defeating the expedition before Congress. I have told you the device was appreciated by that body ; that you were pitied for its weakness; and that, had it not been for your official promise, yet unfulfilled, that you would do your duty, you had probably heard something on this subject which, for aught I know, may still be in store for you, "nursing its wrath to keep it warm."

Suppose you obtain permission from the president to send in a little message from your department on the first of next month, 
asking of that honourable body to give you a new hearing. Tell them that, from the vast demand the exploring squadron will make upon the specie; the exposed condition in which it will leave our commerce in the Gulf of Mexico; the utter derangement into which it will throw the whole naval service of the country, which may go far towards breaking up all our foreign naval stations, and on numerous other grounds, you think you can make one more hard battle against the "whole concern." I will help you, as far as in me lies, to get this new trial.

The column of extracts from your reports republished by "A Friend to the Navy" requires no further notice from me. The sections quoted have all been examined in my preceding letters, and the public will judge between us.

A "Citizen" does not think that the vessels of the "squadron should have been sent out long since, fit or unfit;" but he does think they should, and, with good faith in the department, he is quite sure they might, have been long since despatched to sea, completely equipped!

I cannot forbear to notice a paragraph at the close of "A Friend to the Navy's" first article. It reads thus: "Now, although it is very pleasant weather here in June and July, it is quite the reverse at Cape Horn; it is winter there, and the officers of the navy would prefer a different season for doubling the cape, if a 'Citizen' will permit them."

This Addisonian sentence was doubtless intended as a pungent or witty retort, I do not know which, to my remark that, had you done your duty, the expedition, to say the least, would "now be doubling the cape, and every one engaged in the enterprise full of hopes of having immediate opportunities of fulfilling their country's expectations." Truly, you pay a high compliment to the nautical skill and disregard of personal exposure which I had hitherto supposed a characteristic of the officers of the navy, and which, I presume, is characteristic of them, unless they have lost all such qualities since you have been the official head of the service. You will learn, on inquiry, that the bugbear of doubling Cape Horn has passed away in the minds of all whose reading has come down to a later date than the days of Magellan, Anson, Davies, Schoten, and Le Maire, and that this passage is fearlessly encountered by our whale fleet, on their outward and homeward passages, 
without stopping to consider what month will bring them off the cape. Numbers of our fellow-citizens engaged in other occupations, and that, too, not unfrequently, in vessels little larger than pilot-boats, make the passage at all seasons. But these are merchantmen, and the "officers of the navy," says their judicious friend, "would prefer a different season for doubling the cape" than the terrible months of June and July. It is to be hoped they will exhibit a due sense of gratitude to the friend who kindly makes known to the world his endeavours to gratify them in so commendable a preference. How you can think of allowing officers to go as near as possible to the South Pole, whose lives you would not risk in doubling the cape in winter, I have yet to learn.

In conclusion, if you have any influence with "A Friend to the Navy," advise him to keep his temper, as well as more closely to his text; counsel him to be careful how he wages a war personal and vindictive with me. I have thus far confined myself to the record, and the subject at issue between us; tell him that whether I am Mr. This or Mr. That is no concern of his. I have to do with you and with the expedition; let him answer for you as he can, but inform him that shrinking from the main points of a controversy, and the substitution of personalities for arguments, are ever the dernier resort of a puerile, malignant, and defeated adversary. Should it ever be discovered that such subterfuges were used by a person high in place, they will be considered little to his credit. People will be apt to say that the thick integuments of his conscience had been penetrated; that he felt the sting, and was writhing under the merited chastisement of "Citizen," whose homethrusts have told exactly where he wished, and the public good required that they should tell.

With great respect, I have the honour to be

Your most obedient servant and fellow

CITIZEN.

New-York, August 18, 1837. 
DEFENCE OF THE SECRETARY OF THE NAVY.

III.

$H_{A D}$ the "Citizen" been satisfied with the sıop-of-war, and such smaller vessels as might be necessary for a surveying and exploring expedition, with crews amounting to about two hundred and fifty men, such as was intended by the law of the 18th of May, 1836, it might have been sent out before the meeting of Congress in December last, with such books and instruments necessary for the scientific corps as could be procured in the United States, and the appropriations would have covered the expense; but when it was determined that a frigate and a large store-ship, then on the stocks, together with two brigs and a schooner, not then begun, should be employed, with crews amounting, officers included, to more than six hundred men, it was evident that another session of Congress must elapse and further appropriations be made before this fleet could be sent to sea. Yet the "Citizen" is furious at the delay which his own plans have created, and the secretary of the navy is held up to obloquy in the public papers because the expedition is not now doubling Cape Horn.

The "Citizen," in his present state of mind, no doubt thinks that everything should yield to the expedition; that providing for the Pacific, the Brazilian, and West India stations was comparatively but of little importance, and that the small delay from the passing the act authorizing the expedition to the close of the session was not to be tolerated. "May and June," he says to the secretary, "passed away, and no step had been taken by you to put in train the preparations for the expedition. You now began to speak plainly, and to hold the language that twelve months would be necessary to complete the outfit."

The act authorizing the expedition became a law on the 18th of May, not on the 10th, as frequently asserted by the "Citizen." It authorized the president, not the secretary, to fit out the expedition. The secretary's authority did not commence until instructed by the president. 
As the attention of the president was incessantly called to subjects of great importance, pressed upon him at the close of a most arduous session of Congress, the exploring expedition was suffered to rest for a few days.

Soon after the middle of June the secretary was instructed to write to the officer selected as commander of the expedition. This was done without delay; some days were spent before the necessary consultations with this officer could be had as to the vessels to be employed; whether a sloop-of-war as a flag-ship and smaller vessels, or whether a frigate, a store-ship, two brigs, and a schooner; whether ships should be repaired, purchased, or built for the purpose; all these points required and received a few days' consideration.

The secretary, as soon as he was authorized to do so, gave orders for preparing the ships and for recruiting the seamen. On the 6th of July he gave orders that the frigate Macedonian should be completed without delay, and on the 7th, 11th, and 20th of that month orders were given for preparing to build the brigs Pioneer and Consort, and schooner Pilot, with the least practicable delay. The completion of the store-ship Relief had been previously ordered.

'The recruiting for this service was put under the superintendence of Commodore Jones, and Lieutenants Tatnall, R. R. Pinkham, Purviance, and H. W. Morris were ordered to report to him for duty in this recruiting service as soon as he required them; and others were subsequently ordered at his request for the same service.

An agent, Lieutenant Wilkes, was selected without delay to go to Europe for the purpose of procuring such instruments and books necessary for the expedition as could not conveniently be procured in the United States. A few days' preparation was in. dispensably necessary in this rase; but Licutenant Wilkes embarked at New-York for Liverpool on the Sth of August.

In all this the "Citizen" can see nothing but insufferable delay, for which he holds the secretary responsible. His perceptions have become confused by the monomania under which he has laboured for the last twelve years, which impels him with irresistib'e force to the south, to carry into effect his schemes of circling the globe within the antarctic circle; casting anchor on the point 
where all tne meridians terminate; fastening the star-spangled banner to the pole of the earth itself; and many other vagaries too tedious to mention.

In these preparations none, upon a full knowledge of the case, except the "Citizen," and a few others who have been bitten by him, can see any cause for throwing censure upon the secretary.

These preparations required extraordinary exertions, not on the part of the secretary, for no more was required of him than giving the necessary orders, but of the officers under whom the ships were to be prepared and the men recruited; and particularly of the commander of the expedition, under whose superintendence the whole was placed; and, it is believed, the "Citizen" will not accuse that officer of any want of zeal or diligence in the performance of any duty assigned him.

It, however, suited the purpose of the "Citizen" that these extraordinary exertions, which had not been attended with all the anticipated success, should be considered as the extraordinary exertions of the secretary of the navy. In his fifth number he says to the secretary, "'Thus you tell him (the president), that inasmuch as it was his earnest wish that the intentions of Congress in authorizing the measure should be carried into effect with the least possible delay, you had not only resolved to clothe Commodore Jones with unusual powers, and to grant him every facility for the purpose of shipping crews, but that you had yourself determined to make an extraordinary effort to accomplish that object." The words, that you had yourself, are a fabrication, and are not in the report which he pretends to quote; and this fabrication serves as the basis of a series of misrepresentations about extraordinary efforts.

The language of the report to the president is, "As, however, it was your earnest wish that the intentions of Congress in authorizing the measure should be carried into effect with the least possible delay, and that the expedition should be fitted out upon the extensive and liberal scale which the indications of public opinion seemed to require; and as the officer, Captain Thomas Ap. Catesby Jones, selected for the command of the expedition, gave assurances that the difficulty of obtaining seamen could be obviated by giving him power to have them recruited under his immediate superintendence, and for this particular service it was determined to make an extraordinary effort to accomplish these objects." 
It was unusual to put the recruiting service under the superintendence of a commander of a squadron; it is unusual to recruit seamen for a particular service; yet both are done on extraordinary occasions, and the president, in fact, determined and directed that it should be done in this case. The secretary gave the necessary orders. The extraordinary duties were to be performed by others, not by the secretary. He does not recruit or superintend the recruiting of seamen.

The "Citizen," who seems disposed to regulate the whole police of the navy department, complains that money for advances was withheld from the assistant recruiting officers, without which advances seamen cannot be induced to ship either in merchant or naval service.

Sufficient funds were in the hands of the officers at the head of the respective recruiting rendezvous, and the usual advances were made to the seamen presenting themselves at the receiving ships. To open accounts with all the assistant recruiting officers was unnecessary, and would have been attended with great inconvenience. It was not done for Commodore Ballard; it was not done for Commodore Nicholson; it will not be done to please the "Citizen." The idea of making advances to seamen to enable them to go to the recciving ship is new. Few of them, with such advances, would find their way to the right ships. Recruiting officers know that, after advances are made to seamen, they must be guarded with great care, or they desert.

The "Citizen" relates the case of an officer in the District of Columbia, who had obtained a thousand dollars upon his requisition, approved by the commander of the exploring squadron, which sum he was forthwith ordered by the navy department to return to the treasury.

In May last, when there was no longer any serious difficulty apprehended in recruiting seamen for the expedition, an officer attempted to establish a recruiting station in the District of Columbia, and obtained from the navy agent at Washington one thousand dollars without the consent of the head of the department. It is true, his requisition for this sum was approved by the officer commanding the cxpedition, who had good reason to believe the measure had been sanctioned by the secretary of the navy; otherwise the requisition would not have been approved. 'The transaction 
was irregular, and he was very properly ordered to restore the money. In which case no appeal lies to the "Citizen ;" and if the officer has sent his report of this case to the "Citizen," he has prohably made a mistake in the direction.

The finishing of the frigate Macedonian and store-ship Relief, and the building of the two brigs and schooner, required extraordinary exertions on the part of the officers to whom these duties were assigned, and for the performance of which they are entitled to much credit; yet all this does not satisfy the "Citizen," and in his No. V. he asserts that the Macedonian was not completed and in a condition to receive her complement of men until June of this year. It is believed the "Citizen" is somewhat incorrect; but if what he states is true, is it the fault of the secretary? The expedition could not be sent out upon the proposed plan without the frigate; it was therefore impossible that the squadron should be now doubling Cape Horn.

In March last, and before the Macedonian was finished, as the "Citizen" says, it was discovered, from the sailing of the Pioneer, that she was not fit for service in this expedition; and the Consort and Pilot were believed to be in a still worse condition. Until the necessary alterations shall be made in these vessels they cannot be sent out as a part of this exploring squadron; so that, in fact, there has been no time at which this squadron could have been sent to sea, even if there had been no difficulty as to recruiting seamen. In this no delay was feared after the time that the vessel could be prepared; and the secretary, in his report to the president of the 6th of February last, says, "the difficulties which have retarded the recruiting for this service are nearly obviated; and it is confidently hoped that in a short time there will be sufficient numbers recruited to complete the crews of all the vessels of the squadron."

The "Citizen" very unnecessarily works himself into a fury about the Macedonian; in his same number five he says to the secretary, "In speaking of the vessels, you proceed to tell the president that 'the frigate and store-ship which were on the stocks when this measure was authorized have been finished and equipped, and are now receiving their crews.' What unaccountable hallucination could have possessed your mind when you wrote this sentence? Did you, in the first draught of your report, put down what ought 
to have been the condition of those vessels, and afterward forget to alter it? How else could you venture to tell the president, and, through him, Congress and the whole country, that the frigate was finished and equipped, and was receiving her men, when the fact was, that the frigate, at that time, was not finished, not equipped, nor was she receiving her crew; so far from it, she had not a bulkhead up or a yarn over the masthead; and it was not until June, six months after this official statement, that she was completed, and in a condition to receive her complement of men!!!"

One would suppose, from this flourish and bluster, that some terrible deception had been practised upon the world.

Commodore Warrington reported to the secretary that the Macedonian was launched on the 1st of November. As this was the flag-ship of the squadron, Captain Jones was ordered on the fifth of that month to report to Commodore Warrington for duty, as commander of this squadron. He had before reported on the $3 \mathrm{~d}$ of October, that, up to the 26th of September, one hundred and nine able seamen, ordinary seamen, and boys, had been recruited for the exploring expedition; and that Captain Armstrong stated that, as the service was popular, he looked for much better success. There was no doubt of the zeal of Captain Jones in putting his flag-ship in a condition to receive her crew. One month after this time, when the secretary made his report, he was justified in believing that the Macedonian, as well as the Relief, were so far finished and equipped as to be receiving their crews, and so stated in his report to the president of the $3 \mathrm{~d}$ of December. It seems the Relief was so far finished as to be receiving her crew, but that the frigate was not. Commodore Jones, on receiving this report, would have stated the error had he deemed it of immediate importance, and on the $31 \mathrm{st}$ of January he reported to the secretary that the Macedonian was launched in October from the Navy Yard at Gosport; that, from the latest information, she is not yet ready to receive her crew, though she probably will be by the time the scientific corps can be ready to embark, and a sufficient number of men obtained, for which prospects are becoming more favourable. This information was communicated to the president, and, through him, to Congress and the whole country.

'This differs, however, very much from the statement of the "Citizen," that the frigate was not in a situation to receive her 
complement of men until the month of June. Perhaps some unaccountable hallucination has possessed the mind of the commodore.

The "Citizen," in continuance, says to the secretary, "The president is further informed that you had not yet attempted to organize the scientific corps for the expedition, but you intimate that this duty may be performed as soon as accommodations can be afforded them in the vessels. Strange incongruity this! In the first place, the vessels are finished, and receiving their crews ; in the next you tell us that the organization of the corps is delayed until the vessels are finished and ready to receive them." The last sentence is a pitiful fabrication of the "Citizen," and is not to be found in the secretary's report. The language of the secretary is, " the scientific corps may be organized as soon as accommodations can be afforded them in the vessels of the exploring squadron."

The accommodations for the scientific corps will be something different from the mere finishing the vessels so as to receive their crews. 'The Independence was finished, and her crew on board, before the accommodations for Mr. Dallas and his family were prepared. But it is disgusting to pursue farther these pitiful misrepresentations.

"The "Citizen" in No. II. vents some terrible threats, which have not yet been carried into execution. He says to the secretary, "Permit me to call your attention to the very last paragraph in the able report to which I have alluded" (a report from the committee of commerce); "it is much to the point, and you may draw instruction from it. Yea, more, it will furnish you with an argument to refute the contemptible fabrication of the weak marplotting enemies of this truly national enterprise, who, in the face of two hundred pages of printed documents, have had the effrontery to say the expedition would have little or nothing to do with the protection of commerce in the regions to be examined. I will give the authors of this device a withering review before I have done. Let them prepare for it. I know them, and may feel it my duty to drag them from their dark retreats, perfectly regardless who may be found in their company, or what aspect they may wear when exposed to the fair face of day." Who these miscreants are I cannot imagine, and the "Citizen" does not think proper to inform us. Perhaps he means the members of Congress who 
passed the act of the 18th May, 1836, expressly limiting the exploring expedition to a sloop-of-war and smaller vessels, and its objects to those of surveying and exploring. This body is probably the only one who have acted in the face of two hundred pages of printed documents, or ever read them. 'Two hundred pages of printed documents! They must have amounted to the size of a cheese! The audacious wretches! The "Citizen" in mercy gives them notice to prepare for a withering.

It is probable that these two hundred pages of printed documents were composed, in part, of the report of the "Citizen" himself of the 29th of September, 1828, describing certain islands, reefs, and shoals in the Pacific Ocean, \&c. If so, I have something to say respecting these two hundred pages of printed documents, which ought to be considered in extenuation of the offence of those who have excited the wrath of the "Citizen." This report, if it is to form the guide for the movements of the exploring squadron in the Pacific, will as certainly involve them in trouble as they double Cape Horn.

If the "Citizen" shall be the Palenurus of the squadron, with his report for his guide, he will swamp the whole concern, and will never cast anchor at the point where all the meridians terminate, nor leave the star-spangled banner to wave on the axis of the earth itself.

In 1828, soon after this report was made, a copy of it was sent to the vice admiral. Kruzenstern, of St. Petersburg, a distinguished navigator, illustrious for his voyage round the world, seeing it had received the notice of the American Congress, he thought, no doubt, he had gained a treasure of reefs, rocks, and islands, of which he commenced the examination. He soon discovered that the information which the writer had received from the whalers, and which he had reported in his memoir, was not of a nature to inspire any great confidence. 'That in his memoir we see islands bearing the same name, but differing many degrees in longitude; and many others indicated under the same latitude and longitude which certainly were but one and the same island; that we fund in it descriptions of islands so circumstantially detailed, that one can hardly call in question their existence, but of which the nonexistence could be equally well proved, and with the same semblance of truth. And speaking of another collection of a like 
character, he says that it resembles that of the author in this, that it is but a mass of names placed without the least discrimination; "que ce n'est qu'un amas de nommes placès sans la moindre critique."

This is given in the advertisement to his "Supplemens au Recueil de Mémoires Hydrographiques," printed at St. Petersburg, 1835 , pages v. and vi., a part of which I will quote in the admiral's language: "Dans le temps ou le gouvernement Américain se disposait à préparer une expédition pour explorer l'Ocean Pacifique, Mr. Reynolds, qui devait étre le chef de la partie scientifique de cette expédition, présenta au secrétaire de la marine, Mr. Southard, un mémoire dont on m'a communique une copie, et dans lequel il rend compte des résultats des recherches qu'il avait faites dans les différens ports des Etats Unis au sujet des découvertes des baleiniers Américains. Les informations qu'il avait reçues de ces baleiniers, et qu'il rapport dans son mémoire, ne sont cependant pas de nature à pouvoir inspirer une grande confiance. On y roit des iles portant le même nom, et différant de plusieurs degrés en longitude; il en est plusieurs autres, indiquées sous les mêmes latitude et longitude, qui ne doivent étre certainement qu'ure même ile. On y trouve des descriptions d'iles si détaillées, qu'il semblerait qu'on ne peut guère révoquer en doute leur existence, mars dont la nonexistence peut étre également demontrée avec autant de vraisemblance," \&c.

The admiral heard no more of the writer, excepi that, in 1529 and 1830 , two brigs, the Seraph and Annawan, were sent out under Captains Pendleton and Palmer, and that Mr. Reynolds and Mr. Watson accompanied them, en qualité de savans.

As to the character of the "Citizen" as a navigator in 1828 , when he attempted, by his report, to enlighten the nautical world, the amount is soon told. He was a sailor by inspiration, and his voyages had been chiefly made on dry land. How he became a savant remains yet to be discovered.

Thus has this industrious "Citizen" contrived not only to make himself ridiculous in the eyes of all who may read these observations of Admiral Kruzenstern, but to throw some degree of ridicule upon the present exploring expedition.

To divert this ridicule from the officers of the navy who may embark in this expedition, and to confine it to its proper source, 
and to show that the scientific corps selected are not of the school of the savant in question, shall be the peculiar care of

\section{A FRIEND 'TO THE NAVY.}

August 10, 1837.

IV.

Among the gross misrepresentations on the part of the "Citizen," published in the 'Times, none is more frequently repeated or pertinaciously adhered to than this, that the secretary of the navy considers the great object of the South Sea exploring expedition to be an approach as nearly as possible to the South Pole. This, after being stated in a variety of ways, is repeated for the last time in his No. VI. in these words: "Like your statement that to approach as near as possible to the South Pole was the object of the enterprise, it is, to say the least, an evasion of the true purposes designed to be accomplished." And then he exclaims, "If the great objects of the expedition be to go as near as practicable to the South Pole, for what purpose do you send a botanist to that region where no vegetation exists? Why do you incur the expense of sending a philologist to attend to the interesting department of language where there are no inhabitants?" \&c.

Now all this going as nearly as possible to the South Pole is the work" of the "Citizen's" own imagination. 'The language of the secretary in his report laid before the House of Representatives is, "The great objects of this expedition, as understood by this department are to explore the seas of the southern hemisphere, more particularly in high latitudes and in regions as near the pole as may be approached without danger," \&c.

To approach the pole as nearly as practicable, or possible, would be to encounter much danger; but it is distinctly to be understood, from the language of the secretary, that it was not cxpected that such danger should be incurred; and, of course, it could not be expected that the expedition should approach as nearly as possible or practicable to the South Pole; nor, indeed, make any nearer approach to it than could be accomplished without danger.

The language of the secretary was calculated to remove the 
apprehensions of those who might embark in this expedition, that their lives were to be unnecessarily exposed among icebergs near the pole for the purpose of testing certain wild theories that had long been before the public. It was an assurance to them that they should not be carried within the verge of that great opening of sixteen degrees around the pole leading to a concave and habitable world, according to the "Citizen's" former theory as exhibited in his lectures; nor required to do what the "Citizen," in his late address, considers as quite practicable, viz., to "circle the globe within the antarctic circle, and attain the pole itself; yea, to cast anchor on that point where all the meridians terminate; where our eagle and star-spangled banner may be unfurled and planted, and left to wave on the axis of the earth itself! where, amid the novelty, grandeur, and sublimity of the scene, the ressels, instead of sweeping a vast circuit by the diurnal movements of the earth, would simply turn round once in twenty-four hours!"

In a letter of a former secretary of the navy, of the 29th of January, 1829, to the chairman of the committee on naval affairs, to the Senate of the United States, respecting the objects of the South Sea exploring expedition, proposed at that time, it is stated "that the examinations of both known and unknown islands, \&c., will be, in part, in high southern latitudes, and the instructions would naturally and necessarily be to find and describe all which exist there; and as far to the south as circumstances would permit them safely and prudently to go;" so that the views of the former and present secretary are much alike as to the regions in high southern latitudes to be visited by a South Sea exploring expedition. Whether they approach the South Pole as nearly as may be without danger, or advance as far to the south as circumstances would permit them safely and prudently to go, must be nearly one and the same thing.

And does the "Citizen" intend that the object of visiting high southern latitudes, such as can be approached without danger, shall be abandoned? Does he think that such purpose cannot be entertained, because we send ont a botanist to regions where no vegetation exists, and a philologist where there are no inhabitants?

After the great preparations that hare been made for exploring the South Seas with vessels as strong as wood and iron can make them, constructed for the express purpose of maling their way 
through fields of ice, and more fit for that than anything else, the public will expect something more than has been accomplished by any other exploring expedition; more particularly as the " Citizen" himself, in his famous address, page 97, gives it as his deliberate opinion "that the ninetieth degree, or the South Pole, may be reached by the navigator," unless intercepted by land. 'The public will expect that high southern and unexplored regions will be examined by our exploring squadron; and if they return without making a nearer approach to the Pole than any other exploring expedition has credit for, be assured that no small degree of disappointment and mortification will be manifested by those who have to pay the expense of this enterprise.

Although it is particularly desirable to extend our researches into high southern latitudes, yet but a very small portion of time can be devoted exclusively to this purpose. While the expedition is out, there will probably be but two seasons, and those short ones, when these high latitudes can be reached without danger; but those seasons must be improved to the greatest advantage, or one of the most interesting objects of the expedition will be lost. Five sixths of the time of the cruise the squadron will be in lower latitudes and milder climates, making surveys and explorations; discovering islands, rocks, reefs, and shoals; ascertaining latitudes and longitudes; affording aid and protection to our merchants and whalers; rescuing wrecked mariners, and performing a varicty of other duties not interfering with the legitimate and proper objects of a surveying and exploring expedition. But the results of the examinations in high latitudes, in this one sixth of the time, will be looked to with more intense interest than any others of the whole cruise.

The "Citizen" is now endeavouring to divert the attention of the public from these examinations in high southern latitudes, because he knows not what to do there with a frigate of thirteen hundred tons burden and drawing twenty feet water. He will be equally perplexed to know what to do with her among the shoals and coral reefs of the South Sea Islands. But, by way of obviating difficulties, he has determined to convert this surveying and exploring expedition into an expedition for the protection of commerce; the objects of surveying and exploring being considered by him as of secondary importance. In this he will fail. 
In the first place, Congress have made this a surveying and exploring expedition, and not one for the protection of commerce. The armament and equipment of the vessels prepared are entirely different from the armament and equipment of vessels sent out for the protection of commerce. The claracter of the expedition is peaceful. 'The vessels will be prepared to defend themselves, and the vessels and property of merchants and whalers, against the pirates and natives of the regions they may visit, but not to attack armed vessels of any maritime power with which we may be at war.

In this enlightened age, it is understood that exploring expeditions are exempt from the laws of war, and our vessels engaged in this expedition will not be subject to capture.

What can be wanted of a scientific corps on an expedition for the protection of commerce? Nothing can be more incongruous than the slow, patient, and persevering labours of an exploring party, and the rapid movements required for the protection of commerce. Such vessels as are built for this expedition would never leave our ports for the protection of commerce.

But if the "Citizen" shall succeed in changing the character of this expedition from peaceful to warlike, he will still be perplexed with difficulties. Suppose, in clearing the decks of one of the vessels, the frigate, for instance, for action, what a scene of confusion-skeletons and bones of animals of all kinds, testaceous, crustaceous, vertebrated, and invertebrated; heaps of molluscous treasures; alligators stuffed, "and other skins of illshaped fishes," must all, all be tumbled into the ocean without reserve, " rari natantes in gurgite vasto."

The "Citizen" had much better permit this expedition to remain, what it was intended to be from the beginning, a peaceful surveying and exploring expedition.

But he has discovered one important purpose for sending out a frigate which has not been sufficiently noticed. It is nothing less than this, that a salutary effect may be produced upon the fears of the islanders to be visited; and, as he says, "the natives awed into respect by a judicious display of our power." And then he relates the story of Lord Byron with the frigate Blonde at the Sandwich Islands in 1824, and what was the effect produced on the minds of the savages by the presence of that ship, \&c., \&c. 
Will not the large ship Relief, of four hundred and sixty tons, the two brigs Pioneer and Consort of two hundred and thirty tons each, and the schooner Pilot, of one hundred and fourteen tons, sufficiently awe the natives? Must the frigate be added to intimidate the savages? 'The sending out this frigate will increase by one hundred thousand dollars ihe expense of the expedition; but this the "Citizen" will think money well expended, considering how amazingly the natives will be scared.

The "Citizen" may be assured that Congress had views very different from his in authorizing the employment of a frigate on this expedition; and he will find that the naval officers differ from him in this, as in most other points in which he undertakes to regulate the affairs of the navy. It is the glory of those officers to meet an enlightened encrny gun to gun and man to man; but not to cxhibit themselves in big ships to intimidate savages or awe the natives.

'Terror is the favourite means of the "Citizen" for carrying his points. His threats are quite awful; and upon the officers of the navy who have offended him he is about to try the efficacy of his valued remedy.

In his number four he says, "The title of citizen, sir, is a proud title" (meaning, no doubt, his own title). "This is a country of citizens. Citizens make the nary; increase or diminish it at their pleasure ; appoint and support its officers, and will judge them (!!); for every year he is on active duty an officer may be two on shore, receiving pay in the latter as well as in the former case." "Let them indulge in illiberal, contracted feelings of petty jealousy against the appointment of citizens to their appropriate provinces, and they will soon find themselves in the hands of a giant who knows his power, and will use it."

Now this giant must be the "Citizen" himself, as he could not be certain that any other giant knew his own power, or that he would use it. And as it is believed that the officers of the navy have not indulged themsclves "in illiberal, contracted feelings of petty jealousy" against any gentleman of science selected for the expedition, however they may have manifested their aversion to a pretender who seems disposed to regulate the whole enterprise, they have nothing to fear but from the execution of his terrible threats. 
Now let me implore the "Citizen" not to make any serious impression upon the fears of the officers of the navy. Although brave, there are some things of which they stand in awe. They are willing to encounter men, but not giants. They do not fear cannon balls, but may dread "a withering review" from the "Citizen" in the public papers. 'Therefore let me entreat you, "Mr. Citizen," not to intimidate them. Don't, Mr. Giant; do not, in your wrath and fury, play the part of the terrible lion,

\section{"Who roared so loud, and looked so horrid grim,}

His very shadow durst not follow him."

Be satisfied with letting these officers know, as you have done, that they are open to censure when "they claim to assume the performance of duties for which their previous training and distinct line of action have left them totally unqualified." 'That "our public vessels have been round the world, and our officers in them, among islands, and in places rarely visited; but what contributions to science have resulted?" This will be sufficiently humiliating to those officers, who have heretofore believed that among their number were many whose writings have added much to the character of their country for science and literature. Indeed, it would appear, from reading domestic and foreign reviews, that, in these respects, they have gained a high reputation, both at home and abroad. But under this withering review of the "Citizen" let them be humble. If the "Citizen" will only put off the lion's skin, and cease, by his awkward attempts at roaring, to frighten folks who do not know him, the affairs of the exploring expedition will go on much more smoothly.

Every measure has been adopted for making the necessary alterations in the two barks and the schooner for the expedition, and they will be as soon fit for service as any vessels like them erer can be.

There is still much reluctance on the part of the officers to join the squadron; but it is believed that a sufficient number will be induced to enter this service as a matter of duty, and that they need not be compelled to this by finding themselves in the hands of a giant.

Great confidence is placed in the gentlemen of the scientific corps. Their competency to perform the duties that will be respectively assigned to them with honour to themselves and their country is undoubted; and from their urbanity, prudence, and 
discretion, it is believed they will treat the officers of the navy with whom they may be associated with the respect due to their character and profession.

Although the secretary of the navy believes that a smaller force for the exploring expedition would be more efficient, and that a frigate is a larger vessel than this particular service requires, yet, as their employment is authorized by Congress, he has given all the orders necessary for having them fitted and prepared for this service, and doubts not, we are aware, that from the enterprise much benefit will result to the commerce and navigation of our country, and great advances made in many important branches of science. It has been shown, however, that he believes that all these results could be obtained at one third of the expense of this expedition, and with a tenth part of the noise. He has some oldfashioned notions of economy about him, which many believe to be out of time and out of place. But he considers a million of dollars worth saving. It would, in his opinion, build a drydock, and he would not give one drydock for a mountain of molluscous treasures.

$\Delta$ ugust 25, 1837.

\section{A FRIEND TO THE NAVY.}

\section{CITIZEN'S LETTERS.}

\section{VIII.}

To the Honourable Mahlon Dickerson, Secretary of the Navy. Sir,

What "A Friend to the Navy" said in his first number has been examined. 'That illustrious writer very complacently commences his second by assuming that the facts stated in his former communication had entirely exonerated you from all censure, both as to the tardiness in shipping men and the delay which had occurred in preparing vessels for the expedition. If you can feel any self-gratulation in his defence on these points, I should deem it cruel to disturb your quiet enjoyment of it; so I shall pass on to notice some of the positions assumed by you or for you, which are among the most extraordinary it has ever been my lot to observe emanating from a dignified snurce. I shall take them up in order. 
In the first place, sir, allow me to ask what is meant by the following :-

"There has probably been no secretary of the navy who would not gladly have engaged in sending out an exploring expedition if it could be done in accordance with his own views, and without embarrassing him in other official duties of more immediate importance and of higher responsibility."

Are you aware, sir, of the indefensible character of the sentiments expressed in the above extract? Is it less than declaring that the will of Congress may be trifled with, as in the case of this expedition it has been, unless the forms of the law, and the time and manner of passing it, shall coincide with your peculiar views of public duty? Shall the nation remain stationary as regards knowledge and improvement, nay, sir, go back half a century in intelligence, ere its schemes of public utility can receive your sanction?

You would graciously condescend to fit out an expedition, provided, "it could be done in accordance with your views!" Should not Congress take a hint from this potential rule, quoted as the guide of your official action? Would it not be a saving of much time, trouble, and money, if that body were to appoint a joint committee, whose high duty it should be to ascertain at all times what laws, and what modes of enacting them, meet the "views" of the honourable the secretary of the navy? Or, perhaps, the same end might be more easily attained by a saving clause in all bills connected with the naval service; as, Be it enacted by the Senate and House of Representatives that the President of the United States be, and he hereby is, authorized to do so and so, provided there is nothing as regards the origin or passage of this bill disapproved by the honourable secretary of the navy, or that may in any manner embarrass him in the discharge of other official duties of more importance and of higher responsibility!!!! And, sir, by what standard are the acts of "more importance and higher responsibility" to be estimated? Is the decision to be left solely to the discretion, feelings, prejudices, or, if you please, the judgment of the head of the department? Who can set limits to the train of evils consequent on the establishment of such a precedent? What assurance would the nation have that its laws would be faithfully executed? None whatever. Fortunately, however, 
the quarter from which such anti-democratic doctrines come is not calculated to gain them any unusual favour in the public mind.

The lachrymose tone so characteristic of your annual report is even more conspicuous in the second number of "A Friend to the Navy." Indeed, I doubt if your most charitable supporter would be able to point out a single manly expression in anything you have written connected with the enterprise ; equally fruitless would be his attempt to select a solitary recommendation in which the noble and enlarged views of the liberal and strong-minded statesman can be even faintly recognised.

From first to last, in conversation and in all your reports, one meets with nothing but a grumbling, fault-finding spirit, in which it is difficult to say whether perversity of temper or narrowness of policy is most obvious.

I should be pleased to see one incident pointed out, whether connected with the plan of the voyage, its objects, the construction of the vesscls, the appointment of officers, or having any bearing, real or imaginary, on the undertaking, from which an excuse for delay or a pretext for dissatisfaction could be drawn, of which you have not availed yourself to the utmost for these purposes. Thus it was again and again asserted that the protection of commerce in 1836 was more than the department could manage, without the "new duties" of fitting out the expedition. But, that I may not do you injustice on this point, I will let "A Friend to the Navy" speak for himself.

"The imposition of new duties in fitting out an exploring expedition could not fail to increase the difficulties of his (the secretary's) situation without relieving him of the responsibilities; which effect they have had, to the most serious injury of the service. It is not strunge that the secretary should feel opposed to the imposition of new duties at a time of such difficulties!!!"

Is it not enough to provoke a smile on the steeled countenance of a stoic to hear of the onerous duties of the secretary of the navy? From 1797, when the nation had a navy to create, through the quasi war with France, during the war with the Barbary States, and subsequently with the first naval power in the world, down to the present day, nothing like your piteous groaning had been heard.

No such melancholy complainings escaped your predecessors, 
sir, when they had everything to originate and determine; to fix on rnodels for vessels; to range the country for timber; cordage to manufacture; copper to import; cannon to cast; but now, when a board of raval commissioners are in constant session to price and purchase all materials; when naval architects are appointed, and "all appliances and means" are in readiness, we hear of the "difficulties of your situation," "the imposition of new duties," and other wild phantoms of the imagination born only in the brain!

There is one way to throw off the burden of these "new duties" and "responsibilities," which I will point out, and which the whole community, and especially the naval service, would feel much pleasure in seeing adopted; resign, sir, a station, the duties of which, from your own showing, you find it so difficult, if not impossible, to perform! But, before you take this step, do let the country know in detail how the naval service has been "seriously injured" by the exploring expedition. In other countries such undertakings have been considered most honourable to the naval profession.

As regards the French expedition, intended to sail on the 15th of this month, and which your dilatory action has allowed to precede the American, such is said to be the enthusiasm elicited that some of the most promising youth in the kingdom have volunteered their services even before the mast; while you hold up a similar enterprise as degrading to the officers of our navy!

Perhaps you meant the following incongruity as evidence that the expedition has been of the most " serious injury to the service :"

"Nor is it strange that he (the secretary of the navy) should be opposed to the manner in which the provision for the exploring expedition was introduced into the general appropriation bill for the navy."

"Early in the session this bill had been sent from the House of Representatives to the Senate; there an amendment was proposed authorizing this expedition; and there it remained, loaded with this rider, until nearly the time of passing the bill on the 18th of May, 1836, more than five months after the commencement of the session, and when the naval service was greatly embarrassed for want of the appropriations."

This is not the first time I have heard of your high dispicasure 
against the committee on naval affairs in the Senate for their audacity in presuming to add an amendment providing for the expedition to the bill for the general service, without having first procured your gracious permission, and ascertained that the thing could be done "in accordance with your views;" but it is the first time I have seen this presumptuous censure in print! Nearly five months, we are informed, did this bill remain in the Senate; yes, there did it remain, loaded with this "rider," to "the most serious injury of the service." To this "rider" is attributed all the delay, from the early part of the session, when you inform us the bill was sent to the Senate. The only "rider" of leaden weight upon the expedition has been yourself, and I very much fear it will yet be the death of you! But did you hazard nothing in the statement that the "rider" to which you allude had protracted the passage of the bill from the early part of the session till nearly the middle of May?

Now, sir, let it be seen how a few plain facts from the record shall put you down. Bid the busy functionary, ever near your person, bring the journals of the Senate and house and lay them on your table. I am much mistaken if you do not find that the house did not take up the naval bill, in committee of the whole on the state of the union, until March 30, 1836. Search the record from that date, and you will find that the bill was read a third time and passed on the 7th of April, four months and seven days after the session had commenced, during the greater portion of which interval, according to your showing, the bill was detained in the Senate groaning under this "rider," to "the most serious injury of the naval service."

What, then, was the time this bill did remain in the Senate? Look at the journal, and see if it did not pass that body on the 28th of April. Only twenty days were occupied by the naval committee in passing on the whole bill, with all its details and heavy appropriations; in getting the documents printed; and in carrying the measure through the Senate. But, sir, even this delay of twenty days was not chargeable on the "rider" providing for this enterprise. I tell you, sir, and I appeal to the committee to confirm the truth of what I say, that the said "rider" did not detain the general bill one hour. The committee were unanimous, the Senate nearly so. When the question was put, "shall 
the amendment be engrossed and the bill read a third time?" it was determined in the affirmative without debate. Yeas fortyone ; nay one.

But this is not all. Memorials from Connecticut had brought the South Sea expedition before the committee on naval affairs in the Senate from the first part of the session. That committee examined into the policy of the measure, and, without division, reported a bill to the Senate providing for the expedition on the 21 st March, before the bill for the general service had passed the lower house; so that, when the latter did reach the Senate, the committee simply added as an amendment to the general bill what they had previously determined on. Neither in the committee, therefore, nor in the Senate, did this amendment and "rider" cause the least detention.

Thus saith the record; in the face of which, for the evident purpose of casting odium on the committee, and of justifying your animosity to the expedition, was the statement I have disproved brought forward. Having no doubt that the committee are both competent and ready to answer to you and to their country for their proceedings in this matter, I commit you on this point, without further comments, into their hands, to dispose of you and your implications as the public good shall seem to require!

" Much delay has taken place," says "A Friend to the Navy," "in consequence of the condition of these vessels."

The amount of labour requisite for all the proposed alterations would not, I should suppose, occupy more than thirty days in any well-regulated private shipyard.

"The officers who have entered the navy with the hope of distinguishing themselves in battle for their country" look, we are told, with little interest to a service so pacific as a surveying and exploring expedition. The love of honourable war is an infirmity of noble minds, and may, by the gallant and brave, be forgiven; but this assumption by a ministerial officer of so decided a belligerent temper may prove dangerous to the state, and should be treated with severity, otherwise what a warlike nation we should speedily become under your management of the navy! If, however, the desire to distinguish themselves in battle be the motive of our youth in entering the naval service of their country, then should it be the policy of government to cherish this feeling, and, as fre- 
quently as convenient, allow them an opportunity of putting theit ardour and courage to the proof. I should think under your di rection we might venture to fight Mexico, or, perchance, one of the Neapolitan states!

From this lofty martial tone "A Friend to the Navy" comes down to the use of language which evidently shows the contempt with which he would inspire the profession for all the duties of the service save "battle." Hear him.

"Respect is due to the pride and feelings of gallant officers of whom unusual, unexpected, and subordinate duties are required. Great additions will be made to science highly interesting to gentlemen engaged in making discoveries, and highly honourable to the country; but somewhat irksome to officers performing a subordinate part in these operations, and who aspire to service more properly belonging to their professional duties."

"To such labours and discoveries no more force should be employed than what is absolutely necessary." Can any one read the above extracts, and fail to perceive the obvious design of the writer? Would you not be ashamed to append your name to a document containing such sentiments? You have at all times urged the reluctance of officers to enter this service; do not the foregoing quotations convict the writer of unworthy efforts to produce that very feeling? Have you not frequently predicted that disagreement and bickerings would occur between the officers and naturalists; and do not the passages transcribed prove the full intentions of the author to bring about the very evils you have prophesied? Does the functionary who is capable of labouring with such intent deserve the cognomen of "A Friend to the Navy?"

Is it an irksome and subordinate duty to protect the commercial interests of our country; to cxplore new regions; succour castaway seamen; make charts of harbours; survey dangerous passages and important groups of islands ; to "bind down the strong arm of the mutineer;" hold conferences with the natives; increase our trade; and render more sccure the lives of our mariners? All these, you would teach, are but "subordinate" duties, and quite beneath the ambition of men who have entered "the service with the hope of distinguishing themselves in battle!!!!"

Why have you not been more explicit in pointing out wherein 
the employment of naturalists will interfere with the claims to those honours and distinctions which, by the common consent of all enlightened countries, have ever been accorded to naval officers engaged in enterprises similarly noble, humane, and beneficial in their objects? Would their labours be other than honourable provided no naturalists were to accompany the expedition? Will you indicate how they can be less so because accompanied by scientific men without nautical knowledge or pretension?

Were the military chiefs under Napoleon less distinguished because savans were attached to the expedition to Egypt? Was not the glory of the former rather embalmed and rendered more imperishable by the discoveries of the latter; and that, too, without filching a single leaf from the laurel which inwreathed the soldier's brow? So will it be with all concerned in this undertaking, and "A Friend to the Navy" will be foiled in his dark, I might say malignant, efforts to sow the seeds of discord among high-principled individuals, who feel the weight of responsibility they have assumed, and be brought to feel that petty jealousies, alike unworthy of officers and civilians, are harboured only in envious and contracted minds!!!

We are next informed by "A Friend to the Navy" that expeditions sent out by other countries have generally been small; and that " among the most splendid exploring voyages of modern times is that of the Astrolabe, a corvette of eighteen guns and eighty men."

Now, sir, allow me to inquire, how can you answer to the country for your late shocking prodigality in the force you have employed to make a few soundings on George's Bank? Have you not sent on that service a vessel of eighteen guns and eighty men, besides an additional chartered force? Surely you have lost sight of the exposed condition of our commerce in the Gulf of Mexico, of which we have heard so much, as well as of the wants of the service on other stations, upon the requisite force for which the South Sea expedition has made such fearful inroads! Did the duties to be performed at George's Bank call for a larger force than that of the "most splendid exploring expedition of modern times?" and yet you have employed a larges force upon it. After this, it is hoped the country will hear no more about the vast scale on which the South Sea expedition is authorized to be 
fitted out; it bears no comparison with your outfit to George's Bank, the magnitude of the respective objects and labours of the two enterprises being taken into consideration. Yes, sir, and while on this point there is one more little question which I wish, in the politest manner imaginable, to propose to you; it is this: How did it happen that you gave permission to the officer having charge of the survey on the banks to take what instruments he chose from those procured expressly for the South Sea squadron, and purchased with the funds appropriated for that exclusive purpose? I would also further inquire if you intend to detain the expedition till the return of the Porpoise, or is it to procecd to sea minus the alstracted apparatus? 'The best way to get out of this difficulty is to be candid, and own what I have no doubt are the facts of the case, viz., that when you gave the permission referred to (for withont it I cannot suppose the instruments to have been taken), you had just hit on the plan of your famous commission; and entertaining no doubt of being sustained by the board, either wholly or in part, in breaking down the expedition, you considered that this sending off the apparatus was only taking time by the forelock, and adding one more to the list of difficulties already, according to your statements, so overwhelning !

At length we have something like an outline of the character and force you would sanction in an expedition to the South Seas. True, you have not condescended to go into detail or explain how its varied labours could be accomplished with that force, and it were wise in you to abstain from any attempt to do so. Here is your plan.

"Two ships would be quite enough for the purposes of survey and exploration on this South Sea expedition, and an additional vessel for the search of wrecked mariners."

It were an easy matter to show the utter insufficiency of what you here recommend, to say nothing about the modesty of the recommendation after the adoption of the present force by the competent authorities in the first place, and its recent approval by your own commission appointed expressly to adjudge the matter. But it is not worth while to waste time in arguing the point with one who so pertinaciously refuses to understand-or, understanding, continues to misrepresent-the objects for which the measure was authorized. The admission, however, that one vessel ought to be 
sent out for the purpose of picking up lost seamen, is at once singular and amusing, considering the source from which it comes. It is rather a squinting towards an acknowledgment that the enterprise, after all, has something to do with the protection of commerce; for surely there are no mariners to be picked off the istands as near as it would be possible or safe to approacte the South Pole! Why have you not the openness to admit that the Macedonian is the proper vessel for this humane purpose? The presence of such a vessel, by its effect upon the minds of the islanders, would tend to lessen the hardships and dangers of our sailors whom shipwreck may hercafter throw among them. Indeed, this was one among other reasons which induced the late president to adopt her as the flag-ship of the expedition; and so fully was he convinced of the importance of a frigate, that he is known to have said, during the last session, that a ship of that class should form one of the squadron, whether the appropriation, then pending, was made or not.

"A Friend to the Navy" tries his hand at verbal criticism, and, like the wiseacre in the fable, who took a single brick as a sample of the whole edifice, dashes upon a few detached sentences of a certain address on the subject of the expedition, delivered in the Hall of Representatives before the members of Congress on the $3 \mathrm{~d}$ of April, 1836. What that address has to do with the derelictions of duty which "Citizen" charges upon you, has not yet been pointed out.

'Though I cannot say you have evinced the acuteness of Juvenal, the grammatical accuracy of Harris or Gifford, or the polish of that rancorous critic, Dennis, still I must own that you appear to have caught the mantle of old Father Pepys, who, in his memoirs, thus discourseth about Hudibras: "When I came to read it, it is so silly an abuse of the old Presbyter Knight going to the wars, that I am ashamed of it: and by-and-by mecting at Mr. 'Townsend's at dinner, I sold it to Mr. Battersby for eighteenpence." Your critical acumen seems to be of about the same calibre as that of the censor of Hudibras; and I advise you to dispose of this said address as he did of Butler's poem-sell it!

With great respect I have the honour to be

\section{Your obedient servant and fellow}


P.S. No. III. of "A Friend to the Navy" is acknowledged a decided improvement in style, though a sad falling off in temper!

New-York, August 23, 1837.

\section{IX.}

In this paper we publish the concluding address of a "Citizen" to the secretary of the navy. We wish that the discussion had not been so far protracted; we wish that we could have avoided giving pain to any member of the administration; but circumstances were uncontrollable, and the fortune of the exploring expedition, one of the noblest and most important measures ever adopted by the American government, seeined bound up in the prosecution of the discussion. Plain duty, therefore, marked our course, and we have not shrunk from it, however disagreeable it may have been. The letters of a "Citizen" have been distinguished by thorough knowledge of the subject, unbounded zeal in the great cause, a single-minded devotion to its interest, purity of style, force of argument, and logical clearness of statement and induction. Universal public opinion approves warmly of his undertaking, and ascribes to its able execution the welcome improvement in the prospects of the expedition, the probability of its now efficient equipment and speedy departure. For ourselves, we believe well, that, but for the labours of our correspondent, the expedition would not now have been within a twelvemonth of sailing, if it ever sailed at all, unless crippied of all efficiency and capacity for usefulness. The "Citizen" has served his country and the cause of science and humanity nobly; and he has served, perhaps saved, the head of the navy department. We take leave of him with our best wishes for his prosperity and happiness, wherever his sphere of life may be cast.-Editor of the New-York Times.

To the Honourable Mahlon Dickerson, Secretary of the Navy. SIR,

I can only account for the confession made in the first paragraph of your third number by regarding it as another confirmation of the trite saying of the Latins, that "those whom the gods intend to destroy they first make mad." Excuse me for not giving the Roman text: I set oul with the intention of speaking in plain English, and shall not now change my original purpose, though the translation may grate somewhat harshly on your classical ear. But to the confession. "A Friend to the Navy" tells us that, had the expedition been fitted out with a sloop-of-war and such other smaller vessels as the law of the first session of the last Congress authorized, together with such books and instruments as the country afforded, the whole fleet, on that scale, might have put to sea on or before the meeting of Congress in December last; but when it was determined a frigate should be em- 
ployed, "it was evident," we are told, "that another session must elapse, and further appropriations be made, before the fleet could be sent to sea." Is this true? Will the country believe it? If so, into what a condition have you brought our navy, when the head of this great branch of national defence can make so humiliating a declaration to the world! I have already shown that the only departure even from the strict letter of the law was the substitution of the frigate of thirty-six guns for a sloop of twenty-four. What a nutshell to hold so many difficulties. The difference between a sloop-of-war and a frigate! And let it be borne in mind that a report had been made which stated that in ninety days the Macedonian could be ready for sea. This report was made by the commissioners to the president prior to the selection of the last-mentioned vessel. The difference between this ship and a sloop-of-war is twelve guns, and yet the disparity, in fact so trifling, is paraded before the public as a valid excuse for the shameful and unnecessary detention of the expedition. By " extraordinary efforts," however, you have been able to overcome this difficulty in fitting out an expedition at the rate of about one gun per month!!!!

It is a matter of surprise that the confession to which I have referred should have escaped "A Friend to the Navy," inasmuch as you must remember having declared, from the beginning, that the expedition could not sail during the past season. Yes, sir, I remember to have met you in the lobby of the theatre at Washington on the very evening of the day on which the bill passed the house, and that you then remarked, previously to a word being said as to the size of the vessels to be employed, that the squadron could not be despatched that season. I repeat, sir, to me, the "Furious Citizen," did you make that declaration. Do you forget it? Have you forgot, also, how reluctantly you took the measure up when required by the president to do so? Sir, you intended, from the first, to bring the matter a second time before Congress. Will you give the negative to this assertion? And was it not because you felt deeply chagrined at being unable to defeat the enterprise as authorized by Congress?

As a plea in mitigation of judgment, for I cannot consider it offered as a defence, we are told what extraordinary efforts you had used during the month of June, 1836 (I mention the year, lest, 
from the multiplicity and variety of your endeavours to frustrate the enterprise, some confusion should ensue in point of time); which efforts, it appears, consisted in having written to Commodore Jones "without delay," conferred about the vessels, given orders for their construction, and directed that sailors should be recruited to man them. Even the days are named on which the orders were issued, viz., the 6 th, 7 th, 11 th, and the 20 th of June ; and the whole statement is evidently relied on to explain away your subsequent tardiness of action, as also to enable you to exclaim, with an assumed air of candid surprise, that "in all this a 'Citizen' can see nothing but insufferable delay, for which he holds the secretary responsible." After some other samples of twaddling criticism about the South Pole, confirming the observation that

\section{"Great wits, like great states,}

Do sometimes sink by their own weights,"

you very complacently lay the flattering, but, alas! delusive unction to your heart, that none "except the 'Citizen,' and a few who have been bitten by him, can see any cause for throwing censure upon the secretary."

Sir, the public mind has been slow and reluctant to fix its condemnation upon you, but it has been constrained to do so, and the future Plutarch of our republic may indignantly inquire, "Who was this honourable secretary, that he should have so ungraciously endeavoured to thwart the wishes of his country by creating obstacles to the fulfilment of a noble and useful national design?" Think you the brief biographical notice of you contained in the "National Portrait Gallery," partial as it is known to be, will afford a satisfactory reply?

What I stated in relation to the shipment of men, the completion of the frigate and store-ship, and the organization of the scientific corps, you have not denied: the facts cannot be refuted. Not the slightest extra encouragement was allowed by you for the purpose of inducing seamen to join the expedition. 'The Macedonian was not finished, nor was she in a condition to receive her crew, in 1)ecember, 1836, as stated in your annual report; nor did she receive her crew on board until June, 1837. On these points you offer a volume of explanations, about as falla- 
cious and irrelevant to the matter at issue as was the excuse of the individual who wrote a letter and requested his correspondent to pardon errors in orthography, as his knife was so dull that he could not mend his pen. Your explanations are non sequitors of nearly the same calibre, and will probably carry as clear conviction to the mind of the reader. I have no desire, sir, to misrepresent you; the truth is bad enough without any exaggeration. The charges $I$ have preferred against you on account of your official delinquencies have gone to the public through the same channel as your defence, and the public will judge between us.

The words "extraordinary efforts" are not, as stated by you, a fabrication; they occur in your report, and are fairly applicable in the sense in which I used them. It is a shallow evasion to say "the duties were to be performed by others, not by the secretary. He does not superintend the recruiting of seamen." True, sir, you do not personally bargain with the sailor; but it was your duty to afford to others the means by which unusual exertions could be made; and these you pertinaciously refused. If, as you state, "it was unusual to put the recruiting service under the superintendence of the commander of the squadron;" if it were unusual to recruit seamen for a particular service, both of which you own you were directed by the president to see done, the inquiry presents itself, why were not these measures more successful? I have already stated the reason. You refused the necessary means for carrying out this plan of shipping for a special service by prohibiting the offer of all inducement beyond what the ordinary rendezvous afforded. Nay, more: when on a visit to this city in August, thirteen months ago, on seeing the bills up for the special shipment of men, did you or did you not say that you would fix that business by allowing the same privilege in shipping mariners for the Pacific and Brazilian stations; and were not similar placards accordingly posted on the walls, thus rendering the facilities in favour of the expedition a mere mockery? Your assigned reason for not placing funds in the hands of recruiting agents, except at the regular depôts, is pefectly futile, as security for the advances and delivery of the men could have been taken at New-London, New-Bedford, and other intermediate points.

The "threats" in my second letter to give a withering review 
of the conduct of those who had attempted, by misrepresentation of its purposes, to defeat the expedition, you seem to think have not been redeemed. You appear, also, to have some difficulty in recognising the parties to whom I had reference. I have no wish to be obscure, or to leave any doubt on your mind upon this point; I will therefore say at once, "thou art the man" to whom I alluded as being at the head of those who misrepresented the true objects of the measure with the sole view of compassing its utter defeat.

If my review of your official conduct has not been sufficiently "withering," I am quite willing to amend my error; the subject is far from being "exhausted."

There is but one more point in your third number which I esteem worthy of notice. I allude to your sneering remarks on the mass of information treasured up by our whalemen during their voyages in the Pacific Ocean and South Seas, which information formed the subject of a report to the department in 1828; to be found among the documents setting forth the objects of the undertaking.

Who ever vouched for entire accuracy of detail in the doctment you have pretended to criticise? No one, sir, has made such an averment, and of this fact you are perfectly cognizant. The individual you mention as having rendered himself ridiculous through the report in question held the following language in his address before Congress, when speaking of the information that report imbodied.

"That the positions of the islands, as laid down by our whalemen, are determined with accuracy, we pretend not to assert; neither do these adventurous navigators themselves lay claim to any such exactness. 'The very nature of these pursuits almost precludes the possibility of such a result; their primary object being to take whale, and not to make discoveries. When, however, we reflect on the disadvantages under which they labour; unprovided with instruments of improved construction; often computing their progress by the run of the log alone, without allowance for the influence of currents, the force and direction of which they do not stop to investigate, it must be conceded that the information they have imparted is more correct and explicit than we could reasonably anticipate. But if these men have not the 
means and opportunity of noting with precision the geographical position of their discoveries, it is still less within their power to ascertain the capacity, resources, and productions of the new lands. Whale-ships lost in the process of examining a group of islands or a reef forfeit their ensurance. Even were this otherwise, time cannot be spared for such a survey; and thus a brief note in a vessel's logbook is frequently the only recorded notice of a dangerous reef or a new archipelago. It is impossible, however, to examine the reports of our South Sea whaling captains without feeling the value of that mighty mass of rude materials with which they have furnished us. To have those materials carefully analyzed, and a work upon which confident reliance can be placed prepared for future use, is the bounden duty of government. 'The prosecution of these objects will constitute an important part of the labours of the expedition; labours which ought not, in justice, to have been delayed till now. Perhaps the silent and unobtrusive manner in which our great ocean concerns are carried on may, in some measure, account for, if it cannot justify, the negligence of our government in not watching with a more vigilant eye the interests of our civil marine, and protecting it more effectually by the strong arm of naval power. I put the question to every liberal-minded, intelligent individual within these walls, is it honourable, is it politic or wise-waiving the considerations of humanity and duty-to look supinely on, while our citizens are exposed to shipwreck in seas or coasts, and among islands, of which they possess no charts capable of guiding them aright, and to suffer them to be massacred by savages for lack of such a judicious exhibition of maritime strength as would command respect by showing the ability to enforce it? And yet such is the situation of our commerce in many parts of the world."

And pray, sir, what is the language of Admiral Kruzenstein, which you have hunted up, in relation to this same report? Precisely in substance what its author himself held, as will appear from the translation quoted below.

"At the time when the American government contemplated fitting out an expedition to explore the Pacific Ocean, Mr. Reynolds presented to the secretary of the navy, Mr. Southard, a memorial, of which a copy has been communicated to me, in which he presents the results of the researches made by him in the different 
ports of the United States into the subject of the discoveries of American whalers.

"The information received by him from the whalers, and which he communicates in his memorial, is not, however, of a nature to inspire great confidence. Islands may there be seen under the same name, and differing several degrees in longitude; there are several others designated under the same latitude and longitude, which certainly must be one and the same island."

'Thus it will be seen that the authority of Admiral Kruzenstein, so far as it is of any importance, is decidedly against you, and fully sustains all which has been claimed for the document, based on the materials furnished by our whalers, viz., that it goes to show that the knowledge we possess of the Pacific Ocean and South Seas is so imperfect as to demonstrate the utility of sending out an expedition to ascertain and settle what is at present vague and uncertain, and thus give additional security to our commercial interests in those quarters. With these remarks I shall leave you to reflect on the illiberality and injustice of the attack you have made on the enterprise of our whalers, for your remarks will bear no other construction.

And now for the fourth and last article you have given to the public. I shall content myself with a few brief remarks upon this "delectable' production. It bears indubitable evidence that you have become alarmed at the untenable nature of your position, especially in maintaining that the great object of the expedition was to explore regions as near the South Pole as can be approached without danger.

In that number you have, for the first time, been compelled to confess "that from the enterprise much benefit will result to the commerce and navigation of our country, and great additions be made in many important branches of science." For the sake of this confession I am willing to pass over without comment many amusing quibbles and tergiversations incident to your defence, seven eighths of which are utterly irrelevant to the subject-matter at issue between us.

You are now, as I am pleased to learn, doing your duty with a much better grace than could have been expected, considering your late disappointments. 'T'o bring you to this point was my sole motive in addressing you. For the mere sake of controversy 
I should not have written, as I feel no pride in a triumph over you. It is sufficient for my purpose that you have at length been driven to abandon the position assumed in your famous report of April 16, and subsequently maintained in your instructions to the naval board, with both of which the annexed extract from your last letter appears in amusing contrast.

"Five sixths of the time of the cruise the squadron will be in lower latitudes and milder climates, making surveys and explorations ; discovering islands, rocks, reefs, and shoals ; ascertaining latitudes and longitudes; affording aid and protection to our merchants and whalers ; rescuing wrecked mariners; and performing a variety of other duties," \&c., \&c.

This is rational; this is what the friends of the expedition have uniformly declared; but just what you have never, until now, admitted. Go on, then, as you are now doing, to the end. De. spatch the expedition with a just and enlightened liberality; abandon all efforts to defeat, retard, or cripple its efficiency; claim credit for good intentions; protest that you never wished to destroy it, and you may yet receive, if not entire forgiveness for the past, at least a glorious oblivion for the future !

A "Citizen" fully agrees with you in the importance you at. tach to the examination of high latitudes south. He has never maintained other opinions; but he regards it as one objec1, not the great objects of the enterprise. Nor has he ever used any language in reference to the attainment of ninety degrees south which he is not willing again to repeat. In the very document, and in the very pages you have turned over, he has said- "That the ninetieth degree, or South Pole, may be reached by the navi. gator, is our deliberate opinion (unless intercepted by land), which all that we have seen and known has tended to cunfirm. 'That an expedition should be despatched from this country for the sole purpose of ascertaining the practicability of attaining it is not, perhaps, to be expected; but that the effort should be allowed to be made in connection with the other great objects of the enterprise, is perfectly in accordance with the most prudential policy. We shall not discuss, at present, the probability of this result, though its possibility might be easily demonstrated. If this should be realized, where is the individual who does not feel that such an achievement would add new lustre to the annals of American 
philosophy, and crown with a new and imperishable wreath the nautical glories of our country."

Allow me to ask, sir, what you find exceptionable in this language. I do not know that you would rejoice at such an achievement, but I do believe there is not another individual, of the fourteen millions that inhabit our republic, who would not exult in the honour it would confer on the American name.

If I have rendered myself "ridiculous" by what I have said on this point, you will at least find that I stand in pretty good company. Permit me to commend to your especial notice the following account of the French expedition, which your "extraordinary efforts" have suffered to precede our own.

“M. le commandant Dumont d'Urville received on Friday audience of his majesty the king. In the interview, which extended beyond half an hour, his majesty reiterated his wishes that the exploring cxpedition of the Astrolabe and Zelie might realize the anticipations entertained by the former ministers of the marine, and that to France and to his reign may redound the glory of having approached the nearest to the antarctic pole. A reward is promised to the sailors, should they extend their voyage so far as the seventy-fifth degree, and this reward will be angmented in proportion to each degree obtained beyond this designation. 'In case they should approach to the pole,' said his majesty, with enthusiasm, 'then everything will be granted to the sailors that they may demand.'"

Now, sir, does this account of the "enthusiasm" of his majesty arouse no spirit of rivalry in your breast? Does it not suggest an occasion for the American minister of marine to do one act in his official career that shall save the pages of his biography from being consigned to the trunkmakers' and pastrycooks' shops? What is there that you can do to accomplish such a miracle? I will tell you. Just draw up a spirited little report, asking of Congress the authorization of a reward to be given to the officers and men of the expedition for attaining the seventy-fifth degree south, with an appropriate increase for each additional degree even to that point where all the meridians terminate; where our eagle and star-spangled banner may be unfurled and planted, and left to wave at the very pole itself!

Do but this, and 
"Then time shall render to you

The justice that is due you,

Till the very state that grew you

Stares in wonder."

Sir, throughout all the numbers constituting your defence in this controversy you have been determined, from some motive inexplicable to me, that the parties engaged in it should not remain unknown to the public. Of this I do not complain, but have endeavoured to gratify your wish by gently intimating to the community the high source to which it was indebted for those masterly and statesman-like papers bearing the signature of "A Friend to the Navy." It would be uncandid in me, therefore, under present circumstances, to affect that you were incorrect in ascribing to the individual you have designated the authorship of the articles over the signature of "Citizen." This avowal made, I shall reply to your remarks personal with the directness they seem to require ; having hitherto abstained from answering them with the intention of disposing of them en musse. The following is from your No. I.

“'This angry 'Citizen' is no doubt Mr. - - who has succeeded in producing an impression through the country that this is his expedition; an impression much strengthened by the publication in October last of his address delivered on the third of April of last year in the hall of the House of Representatives," \&c., \&c.

Here is a grave charge made by a personage high in place, and the document containing its alleged proof is named. Now, sir, on page ninety-eight of this said address, which lay open before you when you made an extract from the opposite page, ninety-nine, is contained a declaration of my motives of action; and I defy you, or any parasite under your control, to point out a single act of mine which has not been in conformity with the spirit and letter of the sentiments therein expressed; they read as follows :

"We have no narrow and exclusive feelings to be gratified. We wish to see the expedition sail solely because of the good it may do and the honour it may confer on the country at large.

"For the same reason we wish to see it organized on liberal and enlightened principles, which object can be effected only by calling in requisition the known skill of the service, which will 
be found equal to the discharge of every duty in any way connected with the naval profession.

"But this should not be all. To complete its efficiency, individuals from other walks of life, we repeat, should be appointed to participate in its labours. No professional pique, no petty jealousies, should be allowed to defeat this object. The enterprise should be national in its object, and sustained by the national means; belongs of right to no individual, or set of individuals, but to the country, and the whole country; and he who does not view it in this light, or could not enter it with this spirit, would not be very likely to meet the public expectations were he intrusted with the entire control.

" To indulge in jealousies, or feel undue solicitude about the division of honours before they are won, is the appropriate employment of carpet heroes, in whatever walk of life they may be found. The qualifications of such would fit them better to thread the mazes of the dance, or to shine in the saloon, than to venture upon an enterprise requiring men, in the most emphatic sense of the term."

Having, as I trust, satisfactorily disposed of this point, I proceed to notice your remark, that "the extravagances of Mr. have created many difficulties in fitting out this expedition; yet all can be obviated if he will be content with the distinguished and lucrative situation assigned him in the same."

$\mathrm{Sir}$, is it your wish to enter into a full discussion in reference to the position you have assigned me, as compared with the original appointment given me by President Jackson? Are you willing that I should publish our correspondence on this point? Are you ambitious that the public should know how magnanimously you have acted in the premises? I apprehend not; but, if you are, at a proper time you shall be gratified. I never did, I will not at present, obtrude any matter personal to myself upon the public. 'That the expedition should be efficiently organized, and placed in proper hands, I have ever deemed a point of infinitely more importance than the station I should hold in it, or that I should accompany it at all. To effect that object, and to prevent you from destroying the enterprise, have my humble but best efforts been at all times directed; and this, I apprehend, has been "the head and front of my offending." 
Nor will I allow you to justify any portion of your hostility to the expedition on the unsustained assumption that $I$ have created difficulties or thrown obstacles in the way of its earlier completion. As, however, you have chosen to speak of "the distinguished and lucrative situation assigned me," I cannot refrain from informing you that I feel no pride in the distinction your appointment confers on me; that I would not turn upon my heel to preserve it; and that you are at liberty to take it back when you please ; nay, more, that it is your duty to do so, if you were sincere in saying that I "have created many difficulties in fitting out the expedition."

Why, sir, if you were consistent, the very charges you bring against me ought to make me your greatest favourite. When, until in this instance, did you ever complain of any one for throwing difficulties in the way of the expedition? Indeed, rumour saysand I have seen some things which went far in confirmation of the thousand-tongued goddess having for once spoken truth-that those who threw most impediments in the way of the enterprise have been favoured with distinguishing marks of your regard, and have obtained from you almost anything for which they asked; and, further, that, until very lately, the surest passport to your good graces was to attack the exploring expedition. I have heard it asserted that this ruse has been practised more than once, and always with the same distinguished success.

You say, in the conclusion of your third number, that I have not only contrived to render myself ridiculous, "but to throw some degree of ridicule upon the present exploring expedition;" and that "to divert this ridicule from the officers of the navy who may embark in this expedition, and to confine it to its proper source, and to show that the scientific corps selected are not of the school of the savan in question, shall be the peculiar care of A Friend to the Navy." Sir, this manifesto of your "peculiar" intentions does not surprise me. It is only in perfect keeping with your "peculiar" line of conduct towards me from the beginning; and I should feel surprised if it were not continued to the end. I expect nothing from your magnanimity or your justice!

As regards my attainments, I am free to own they are far from equalling my wishes, and by no means what I yet hope to make them. Nevertheless, humble as they are, I can feel little anxiety 
as to their estimate by one who could not, in all probability, find his way across the Atlantic if put to the test; or give the number of cubic inches in a sapling six feet in length and four inches in diameter, though the emoluments of his office depended on the result; one, the barren records of whose entire public life afford not a solitary instance of a useful measure originated or a single patriotic sacrifice made in furtherance of the public good.

With great respect,

I have the honour to be

Your obedient servant and fellow

CITIZEN.

New-York, September 23, 183?.

$\mathrm{X}$.

Exploring Expedition.-We invite the attention of all our readers, but more particularly the members of the House of Representatives, to the letter of "A Citizen" addressed to the secretary of the navy in this day's paper. It will be followed by two others; and upon the facts which these letters will bring before the public we are perfectly willing that the merits and demerits of the expedition, as now organized, should rest.-Editor of the New-York Courier and Enquirer.

To the Honourable Mahlon Dickerson, Secretary of the Navy. Sir,

When I had closed my ninth letter, addressed to you through the New-York 'Times, I felt that kind of pleasure which the mind experiences when an unpleasant, but, at the same time, a necessary duty has been performed. In my correspondence with you, through the medium alluded to, I took occasion to speak of your official conduct, as connected with the South Sea surveying and exploring expedition, with the directness which the subject seemed to require. I charged you with official delinquency, and, in a series of letters, I went into detail for the purpose of showing that the charge was well founded. 'Through the same channel in which my communications appeared you replied, by way of defence, in four numbers, over the signature of "A Friend to the Navy." The controversy became troublesome to you, and I desisted, delighted with the thought that I should not again have occasion to address you. But I was mistaken. 'The expedition has not yet 
sailed. Your annual report shows the quo animo with which you still regard it. New commissions are to sit in judgment upon it ; the delusive impression is still to be kept alive, that a reduction of its force would render it more efficient and more likely to secure the important objects for which it was authorized. Is this true? Why are you not more explicit? Why do you not state what force you would substitute, and show the manner in which the great purposes of the enterprise can be fulfilled by that force? Sir, there is no organization that would suit you. I remember that, three years ago, you were hostile to the measure in every shape and form. I recollect that the year following, when the legislature of New-Jersey passed a resolution recommending it to the favourable notice of Congress, you so modified your hostility as to consent to have the word "exploration" inserted in the general navy appropriation bill for 1836. You would not, even then, listen to the suggestion of an expedition being especially provided for, but said you would send out one or two small vessels, to act under the orders of the commanders of the Pacific squadron. These were your enlarged notions of a great national enterprise ; an enterprise in which we were to make our debût in the field of maritime discovery; and these opinions you expressed in my presence, and in conversation with me.

Sir, the truth is, and of this you are well aware, that, from the beginning to the end, in your private as well as official capacity, you have been an enemy to the undertaking, and never omitted any effort that could retard or tend to defeat it. I do not assert that you have been bold and manly in your opposition. Far from it. At first your attack was open; but, as the current of public opinion began to set strongly in favour of the measure, and the pride, and intelligence, and science of the country became enlisted in its behalf, your opposition assumed a more covert form. You now, on many occasions, professed yourself friendly to the expedition, but then all was wrong about it; another organization would have been the right one; and every available incident was made a plea for delay. If an officer wished to disconnect himself from the exploring squadron, his wish was almost anticipated; if another, from Missouri, was desirous of joining it, he could have permission to do so, provided he bore his own expenses to Boston. Was an excuse wanted for the tardiness of your depart- 
ment in despatching vessels to other stations, the expedition furnished it. Did matters look threatening in the Gulf of Mexico, no vessel was so well fitted to protect our commerce in that quarter as the Macedonian. Did the political horizon betoken a squall in the direction of Mexico, the exploring vessels must be kept at home to fight. 'The banks suspended specie payments, and straightway the difficulty of procuring a large amount in specie to send out in the ships was a mountain not to be got over, though, in sober truth, twenty, or, at the most, thirty thousand dollars would have been an ample supply. 'I'hus have you gone on, virtually trampling upon the laws of Congress, and setting at defiance the wishes of the whole country. That a day of reckoning is at hand is the prevailing opinion, but with that matter I have nothing to do. I have only been induced to take up my pen by the perusal of your annual report, and shall confine myself to an examination of that specious and hollow document.

In looking over that portion of your report in which you speak of the fiscal concerns of the expedition, I find that the three hundred thousand dollars appropriated by Congress in May, 1836, was all expended in preparing the vessels. This is a serious item, and makes a heavy account against the enterprise. But the statement is only calculated to mislead the public. Let it be remembered that sixty-two thousand dollars of this sum went to the completion of the frigate Macedonian; an amount which would have been required from the treasury for the same object under any other head. The store-ship Relief was on the stocks before the measure was authorized; the sum necessary to finish that vessel was nearly as large as that which had been required for completing the Macedonian, and it would have been expended under any circumstances. In addition to these vessels, two brigs of two hundred and thirty tons each, and a schooner of one hundred and thirty tons, were builı, which consumed the residue of the three hundred thousand dollars. Now the two brigs have been compactly and strongly constructed. They will last twenty years, and can be advantageously used as transports, or on other dury, and may be thus employed whether they do or do not sitil on the specific service for which they were intended. 'The schooner Pilot is not worth what she cost; but to whom is the fault attributable? We shall see anon. 
Thus it becomes evident that, in the disbursement of the first appropriation, the country has sustained no loss ; that two ships, partially built, have been finished by the application of this fund, and two other vessels added to our naval force. It is true that the cost of labour put upon these vessels appears very high, being nearly, if not quite, one hundred per cent. more than the same work could have been done for in a private shipyard. But this, if a fault, is to be charged to the manner in which the public work is done, and cannot be attributed to the expedition, or to any one connected with it. If the vessels are not framed after the most approved plan, to whom should the blame be imputed? I have heard it whispered that the first designs made by the naval constructer for the model of these craft were altered. If so, by whom? Certainly not by Commodore Jones. I have before me a copy of a letter from that officer to the naval artificer, where he asks for vessels in which good sailing, good storage, and good acconımodations should be combined; and not one of these qualities was to be sacrificed to another. In this letter he says nothing about length, breadth, or model, but leaves all these matters to be settled in the quarter where they are usually decided. If the schooner Pilot be unfit for the service for which she was expressly built, the Active ought to have been furnished in her stead without additional charge, as a tailor would furnish a new garment in the place of one that did not fit when made to order. If the brigs be what they ought to be, then they are, under any circumstances, worth to government what they cost; that is, as much as anything made in our public yards is worth what it cost; if they are not what they should be, then there has been bad management in some quarter, and the friends of the expedition are not responsible. So much, then, for the three hundred thousand dollars of the million and a half which this prodigal undertaking is to cost the nation.

After showing what was the outlay for these ressels, and charging what had been expended in finishing the Macedonian and Relicf (already under way), as well as the amount disbursed for the construction of the smaller craft, to the account of the expedition, you have carefully added the sum which would be necessary for the support of the squadron during the three years of its contemplated absence, and appear to have felt increased strength, as 
you again threw the whole weight of the department against the measure in the following sentence:

"As this statement of facts could leave no doubt that the exploring expedition would cost nearly, if not quite, a million and a half of dollars, and as it greatly exceeded in number of vessels and men the most successful expeditions of like character heretnfore sent out by the maritime powers of Europe, it was believed that its amount would have been reduced by withholding a part of the appropriation asked for by the estimate. This, however, was not deemed expedient, and the full appropriations were made by an act of the third of March last."

Now, sir, with all due deference, I take up this assumption, which is unsustained by a single argument, and am prepared to show that the exploring expedition, as authorized by Congress and sanctioned by the late executive, in its naval and scientific departments, in all that it is designed to effect, courts investigation, and will bear it. The more closely it is compared with what the maritime powers of Europe have done; the more it is examined and understood by a careful analysis of our interest in and our knowledge of the seas where its labours are to be performed, and an inquiry if the present force be not properly adapted to the faitliful performance of its labours, the more will its friends be strengthened in their position. On the other hand, those who have not had leismre to examine the subject in detail, or have been misled by your objections, ill-founded as they are, will perceive that the great national objects to be attained would justify an increase rather than warrant a diminution of the force at present prepared; and which, but for your hostility to the whole enterprise, might ere now have been in the field of its usefulness, engaged in those investigalions which our interest and our honour equally require should be made.

And what, sir, are the arguments at this day in farour of the design? 'They have been again and again set forth in able reports from committees in Congress, and are understood by the intelligence of the whole country; but nevertheless they receive no consideration from you. It is humiliating to have occasion 10 recur to them at this late period, and I shall do so as concisely as possible. No portion of the commerce of the nation is more inportant than that carried on in the seas which it is to be the chief duty of the expedition to survey and explore.

At the lowest estl- 
mate, twelve millions of active capital are involved in one branch of the whale-fishery, and there are employed in the whole business, directly and indirectly, not less than sixty millions of property, twelve thousand seamen, and from one hundred and sixty to one hundred and seventy thousand tons of shipping. 'The annual income to the United States from this source is between five and six millions of dollars. It is to the protection and safety of this important interest that the expedition has a direct reference, as has been again and again stated in memorials to Congress. 'The whaling business is chiefly carried on in seas more remote and less accurately known than any other regions visited by our vessels. Hundreds upon hundreds of islands and reefs existing there have no place or name on our latest and most approved charts. For instance, there are from one hundred and fifty to two hundred islands in the Fiji group alone, not one of which can be found, with sailing instructions, on any map or chart hitherto published. With this group we have had no inconsiderable trade in native productions suitable to the Chinese market; and the amount of property lost there from the want of a more perfect knowledge of the locality of the islands would pay a goodly portion of the expenses of the expedition. More than one hundred mariners, American seamen, have been shipwrecked, and a large majority of them sacrificed to the murderous cruelty of the natives at the Fiji Islands alone, while we have never endeavoured to overawe the savages by any demonstration of our power, or tried to conciliate them by kindness.

Let us suppose, for a moment, that the exploring squadron has arrived at New-Zealand; perhaps the best point from which to commence its operations, either north or south. Stretching to the northward, the Fijis would command immediate attention. How could the present force be employed in that archipelago? The frigate wonld not be engaged in sounding among the coral reefs; she might take her station in succession at the principal islands, and with her boats and launch, to the latter of which has been affixed a compact, well-made engine, of five horse power, provided by the prudential forecast of Commodore Jones, might survey the principal harbours of the largest island, and of all others within twenty or thirty miles, while the minor ressels would be despatched on more distant surveys to the other portions of the 
group. The frigate would be the headquarters, from whence all subsidiary expeditions would depart, and to which all returns would be made. On board of her the charts would be prepared from the notes and observations of surveying parties; and from her the smaller vessels would receive protection, and every facility in the execution of the duties allotted to them. Upon her decks, or by her officers on shore, conferences might be held with the native chiefs; and if by a mild, conciliatory deportment their confidence could not be won, the formidable aspect of such a vessel would overawe and restrain them. If one of the smaller craft, while engaged in surveys among the islands, or while in a high latitude during the few months of the southern summer when it would be proper to trust her there, should sustain any damage, she could fall back upon the frigate, as upon a friendly haven, for succour and repairs. Shipwrecked mariners now in captivity might be rescued, and their deliverance would, probably, be accomplished by the mere exhibition of a force adequate to compel their liberation. The sick from the store-ship, brigs, or schooner, might be made more comfortable on board the frigate, while from her crew their places could be supplied with fresh hands.

The two largest islands in the Fiji cluster are Navihictevoo to the south, and Fikanova to the north, both of which contain fine harbours. These would form at different times, according to their proximity to the scene of action, the rendezvous of the expedition, while the hydrographical and scientific labours were going on, by means of the frigate's boats and the smaller vessels, in the various portions of the group. 'This archipelago of islands is not a mere collection of barren reefs and sandbanks, but it is inhabited by, it is supposed, one hundred and fifty thousand natives, of whom, as well as of the varicd produce of their country, we possess no authentic information. And yet, from a single port in the United States, we have had near a dozen vessels erigaged, as already stated, in procuring from the members of this cluster such articles as were suitable to the China market. In exchange for these, rich returns have been made to this country, the duties on which have for years added to our national revenue. But these are matters you have studiously kept out of sight in all your reports. If you were ignorant of the facts, which, in charity, I have sometimes been tempted to believe, that you are not disposed 
to become acquainted with them I know from the circumstance that you have avowed yourintention not to look at the memorials to Congress praying for the expedition, nor to the reports of committees setting forth its objects, while making up your mind of what the material and personel of the enterprise should consist, when it was to sail, and what it was to do.

Putling the case that the exploring squadron had accomplished all that was necessary to be done at the Fiji Islands, where would you next direct its course? In every direction from that point it would find duties to perform; but I wish to bring you down from your generalities to something specific, and, therefore, repeat, where would you next direct its course? Perhaps it is not respectful in me to propose this question, recollecting, as I do, that your knowledge of geography and our interest in the seas to which I refer only enabled you to name three places on the globe

- in your general instructions for the guidance of the expedition, and all of these as well known as the port of Brazil, the Falkland Islands, or New-Zealand.

About seven hundred miles northeast from the Fijis lies the Navigator Group. Let this be considered the next point of gencral rendezvous. In the passage thither the lesser vessels might vary their routes, touching at and fixing the positions of the westerly and least known portions of the Friendly Islands; while the frigate might show herself in the principal harbours, hold communications with the natives, and, by so doing, promote the interest and add to the security of our shipping in that quarter. 'The Samoa, or Navigator's Group, was discovered by the French circumnavigator, Bougainville, in 1678, and again visited by La Peyrouse in 1788, more than a century afterward. M. de Langle, the com. panion of La Peyrouse, with a number of his men, were killed by the islanders. In consequence of this catrastrophe, an impression prevailed for many years that these islands could not with safety be visited. Nothing to be relied on in the hydrography was given by the French discoverers; and Kotzebue, who touched at this group subsequently, did not correct a single error of his pre. decessors. Even Norie, in his epitome, gives the names of the islands different from those they bear on his charts of the Pacific, and neither are correct. This archipelago consists of eight islands, and contains not less than one hundred and sixty thousand 
inhabitants. So far from it being unsafe to hold intercourse with them, the natives are now known to be among the most docile of the Pacific islanders. It was formerly supposed that there were no harbours in this group. This is not so; Tutuila has two, in one of which the Pennsylvania, and, of course, the Macedonian, might ride at anchor. Opolu is from one hundred and fifty to two hundred miles in circumference, and has a fine haven open to the nurth. The bottom is sandy, and within twenty yards of the shore there are five fathoms water. A small river disembogues into the bay. One would imagine the Macedonian might get into such a harbour without much difficulty. The largest member of the cluster is Savaii, which is at least two hundred and fifty miles in circumference, with lofty mountains, which may be seen at the distance of seventy miles.

Thus it appears, sir, that one of the most considerable, as well as the most populous groups in the Pacific, lying in the neighbourhood of the Suciety and Fiji Islands, and in the same range with the New-Hebrides, New-Caledonia, \&c., rich in all the productions of the tropics, remains to this day, so far as a minute and practical knowledge of it is concerned, a terra incognitc. Yes, sir, and this is not all; it lies in the very track of our great whaling operations, and a survey of its fine harbours-valuable from their abundant supply of all the varied productions of the tropicswould be of immediate and incalculable advantage to our fisheries and other commercial interests in that quarter.

Thus might I proceed, sir, if the limits within which I must confine myself would permit, to enumerate the islands and clusters of islands which the expedition should visit. I might show how our trade could be rendered more secure, as well as greatly increased, by opening new markets for our agricultural and manufacturing productions. Yes, sir, augmented to an extent of which you probably never dreamed, or, at least, if you had any idea of it, you carefully kept your knowledge perdu while speaking of the expedition. It were an easy matter also to show how one or two of the minor vessels might and ought to make their way south during the most favourable months of the southern summer, and afterward, on the approach of winter in the southern hemisphere, fall back to participate in the surveys going on among the islands. By these efforts to reach high southern latitudes, re- 
peated each year on different meridians, great acquisitions could and would be made to our present knowledge of the southern seas, and the nation would be reimbursed for its outlay by the opening of new channels of trade in animal furs.

Sir, talk as you may about the expense of the undertaking, the country owes the amount, ten times told, for the revenue collected from the varied trade in the regions alluded to; a revenue obtained without the expenditure of a dollar for the protection of the contributors thereto. But even if the debt were not already due to the unaided enterprise of our citizens, the benefits which must follow would repay, with noble interest, the expenses incurred. Who, then, that louks at the great national purposes to be attained, will assert that the force prepared is too large? Sir, it should be increased by two more small vessels of one hundred and thirty tons each, if any alteration be made; and this, too, with reference to its important naval and hydrographical labours, which are the primary and paramount objects that led to the action of Congress. I have yet to speak of the corps of naturalists which has been organized. What, in harmonious action with the naval officers, may be expected from that corps? I undertake to show that no comparison with "the most successful expeditions of like character heretofore sent out by the maritime powers of Europe" will justify a reduction of their numbers. Sir, I will go into the comparison anon in all its bearings, and you shall be welcome to all the support you can draw from it. Upon the issue of that comparison the friends of the expedition might fearlessly rest their cause, as in it they will find a triumphant vindication of what they have done and propose to do, notwithstanding the commission you appointed in June last have told us that, had they "been called upon before any preparations had been made, to state the number and character of the vessels which, in their opinion, would be best calculated to secure the attainment of these proposed objects, they certainly would not have recommended those which have been prepared." Sir, I am astonished that you should have introduced this isolated sentence in your report to the president and Congress, though I can readily perceive the motive for doing so. What, sir, were the "proposed objects," for the attainment of which that board of officers would have recommended a different force? The public will see when the in- 
formation called for is published. In your instructions to that board, sir, you kept out of view all the important and leading operations to be performed among the islands of the l'acific. You told the members that the objects of the expedition were to go as near the South Pole as could be done with safety. Confined to that branch of the undertaking, the force would be too large; and the commissioners, governed by your instructions, did right in saying so. You were grievously chagrined at not being seconded in your plan of mutilation by the report of that body, and, for a time, allowed the preparations to go on with a much better grace than you had previously done, though I never imagined you would permit the squadron to depart before the meeting of the present Congress. 'The condition of the national finances promised you much; while the possibility that Congress, wearied and disgusted with the delay and expenses already incurred, might allow you to break up the "whole concern," or to cripple and send it out on a scale which would mar its usefulness, was doubtless a source of self-complacent reflection to you. Otherwise how shall we account for the fact that, the moment you heard of the greatly-to-be-regretted indisposition of Commodore Jones, you renewed, with indecent haste, your former efforts at cutting down, which, with you, means the same as cutting up? Instantly another commission is organized, with which you hope to succeed, though disappointed by the first. Sir, I respectfully inquire, what instructions have you given this new commission? Have you presented the whole subject, in all its bearings, fully and fairly? Have you handed in the correspondence between Commodore Jones and the former board? If you have done this in good faith, then you will not be sustained. If you have not, the report will be made on a partial exparte statement, and will be undeserving the consideration which the opinion of the officers selected, under other circumstances, would be entitled to. I shall write you again.

I have the honour to be,

Very respectfully, your fellow

CITIZEN.

New.York, December 28, 1837. 


\section{XI.}

To the Honourable Mahlon Dickerson, Secretary of the Navy. Sir,

Perhaps I ought to apologize for affixing your narne to the head of this letter, inasmuch as I now intend to speak of the scientific labours to be performed by individuals attached to the expedition. To this department of the enterprise, notwithstanding all your correspondence with learned societies and your many professions, you are inveterately hostile. Well do you know that the rery measures you are at present urging will break up the scientific corps, and render nugatory all the time and means expended in its ample preparations; that they will destroy the efficiency of the hydrographical department, in which the naval officers, as a body, would find constant and arduous professional employment. Of the duties of the latter, as regards hydrography, I spoke concisely in my last letter. With no complaint from the people in any quarter against the magnitude or expenses of the undertaking, as now contemplated, but, on the contrary, with the public voice everywhere in its favour, you cannot hope to escape the accountability to which your official action has subjected you ; an accountability that few men wowld be willing to incur for all the honours and emoluments of your office, even though the incumbent might hoard up five thousand dollars per annum!

I have asserted that you were hostile to the scientific corps, malgré all you have said and written to the learned upon the subject. You commenced its organization with extreme reluctance; and it is notorious that you used the most extraordinary efforts to create jealousies between its members and the naval officers. When the principal savans were selected, having first been strongly recommended by our learned societies, their appointment was not your act, but the credit of it belongs to the late executive, who compelled you to perform this galling duty. That distinguished individual took a most lirely interest in the expedition; and, as some prominent members now in Congress, as well as yourself, are perfectly aware, was resolved that, so far as he was concerned, it should be sent out in all respects worthy of the na- 
tion from which it emanated. You spoke to him of what other countries had done, and he told you what this country should do. In proof of his design that the enterprise should be all that its best friends desired, behold your own words, quoted from your annual report in 1836, in which you vouch for the late president's liberal sentiments in the following conclusive statement:

"As, however, it was your earnest wish that the intentions of Congress in authorizing this measure should be carried into effect with the least possible delay, and that the expedition should be fitted out on the extensive and liberal scale which the indications of public opinion seemed to require," \&c., \&c.

And how have you fulfilled, how are you now fulfilling, the wishes of the late head of the nation? But I forbear! 'The principal appointments in the corps were made twelve months ago, and its members severally accepted their commissions. Relinquishing all other employments, they held themselves in readiness for active service at a moment's warning; and Congress, at the last session, made provision for their pay for 1837. Some of these gentlemen were connected with the most respectable institutions in the country; and others, to my knowledge, had refused professorships. From December to the 4 th of July last you liept them in suspense, and without salary; although each of them, during that interval, was more or less employed, in some instances under the authority of your department, in labours having direct reference to their duties as members of the scientific corps.

"Thousands at his bidding speed,

Who post o'er land and ocean without rest :

They also serve who only stand and wait."

But I waive, for the present, further details respecting this portion of your official conduct, as I wish to speak of the organization of the corps.

There is no part of the preparations of this expedition, sir, more commendable, in every respect, than the arrangements made for scientific research. 'To enlarge on the utility of such observation would be insulting to the intelligence of all who pretend to keep pace with the intellectual progress of the age. 'The science of the whole country, individually and collectively, is deeply concerned in the result of the expedition. Its votaries have looked forward with pride to the not distant day when this country should. 
wipe off, at one glorious effort, the taunting imputation so long cast upon her character, that she has never contributed to the common stock of knowledge for the benefit of mankind, while she was constantly availing herself of that collected by others. In what manner can youl and your commissions atone to the nation for the frustration of these hopes? I mean to treat the members of your recert commission as I treated the former, with courtesy and fairness. The public, however, will be anxious to see their reports, and the instructions under which they acted. With the cvident effect, if not with the design, of weakening the claims of the expedition, and of producing disaffection towards it in the naval service, you stated in your annual report to the president in I)ecember, 1836, that "scientific researches formed. the most imporlant objects of the expedition." If they were so, why did you nut invite one or two individuals, distinguished for their scientific attainments, 10 meet and confer with your late commission? 'This you did not do, and we shall now behold your efforts to carry out the views of the body; which views, I shall be able to sliuw, go to defeat the very designs which, you have said, formed the important objects of the expedition. Hence it becornes necessary to state the reasons which render this division of the enterprise peculiarly essential to the accomplishment of its desired ends.

The expeditions heretofore sent to the Pacific have, with a few unimportant exceptions, been despatched on some special errand unconnected with general exploration; as the survey of some particular coast, harbours, straits, or group, the observation of some phenomena in astronomy or physics, the opening of some new channel of commerce, or the like; and, of course, the number of naturalists accompanying them was proportioned to their confined field of action. Were this squadron designed merely to touch at a single point, or only to visit islands already partially explored, the number of naturalists would be greater than necessary. But the actual plan of this undertaking is, you must own, altogether different. 'The space within which its operations will be carried on may be said to extend from $20^{\circ}$ north of the equator to the farthest attainable point south, and to comprise the entire breadth of the Pacific, from the western shores of South America to the eastern confines of Asia; for over the whole of that wide expanse we have interests afloat exceeding in amount those of all the mar 
itime powers of Europe combined. This vast theatre of observation embraces islands of all dimensions, from New-Holland and New-Zealand down to the modest coral reef; and includes every climate, from the prolific torrid zone to the extreme limits of animal and vegetable life. I do not affirm that every spot deserving notice can be cxamined by this flotilla; far from it; but I do say that those places promising the richest return in science, and most immediately connected with our commercial marine, can be visited, if the expedition shall depart unshorn of its strength.

If, then, the intended sphere of observation be more extensive than has been proposed in any former enterprise attempted by the European maritime powers, it is only in accordance with our paramount interests; and the number of observers should be correspondingly enlarged, as also their facilities increased. 'This has been done by the selection of individuals, most of whom have given evidence of their qualifications by their previous labours; and all of whom, as before stated, have received the recommendations of persons whose authority in these matters is conclusive.

Let us then take a glance at this corps, as regards its numbers and efficiency, in order that you may have an opportunity of taking specific exceptions to it in detail. Come boldly forward, sir, before the intelligence and science of the country, state your objections, and abide the issue of their verdict. This will be better than to look for precedents as a guide for an enterprise wholly unprecedented in the multiplicity and importance of its objects. I suppose that, in the absence of official communication, the scientific department may be said to consist of :

1. A Philologist.

2. A Meteorologist, to whom is assigned Natural Philosophy in general, or Physical Science.

3. A Chymist, Mineralogist, and Geologist.

4. A Geologist, to whom is especially assigned Organic Geology.

5. A Botanist.

6. An assistant Botanist.

7. An Anatomist.

8. A Zoologist, to whom is assigned Malacology and Actinology, or all shellfish and soft marine animals.

9. A 7oologist, to whom is assigned Entomology, or insects of the land and sea. 
10. A Zoologist, to whom is assigned Ichthyology and Herpetology, or fishes and reptiles.

11. A Zoologist, to whom is assigned Ornithology and Mam. malogy, or birds and quadrupeds.

ARTISTS.

12. A Zoological Draughtsman.

13. An assistant Zoological Draughtsman

14. A Portrait Painter.

15. A Landscape Painter.

16. A Botanical Draughtsman.

\section{MECHANICAL ASSISTANTS.}

17. A Machinist, to repair instruments.

18. A 'Taxidermist, to prepare and preserve specimens.

Thus ten departments only are designated, which are filled by persons engaged in scientific research; two to each vessel of the squadron; and the sum total of savans employed is not so great as has been sent out from Europe on similar expeditions, much more limited in other respects. Nearly forty years ago the French sent out an expedition of discovery under Baudin to the Australian region, called forth by a spirit of emulation and a jealousy of national honour, excited by what the English had done and were doing in that quarter. The enterprise was planned at the time the army of reserve was about to undertake the passage of the Alps. The force consisted of two corvettes of thirty guns each, and a schooner; the corps attached to which included twenty-three persons, viz., two astronomers, two hydrographers, five zoologists, three botanists, two mineralogists, five artists, one gardener and four assistants, one architect and draughtsman. But this is anticipating, as I propose to reserve for my nexi letter a comparison of the present undertaking with what the "maritime powers of Europe" have done. From the majority of former European enterprises of discovery this expedition differs in several essential particulars.

First. In the appointment of a philologist; not a person merely to collect vocabularies, but one versed in the structure and affiliation of languages, and capable of throwing light on the origin, migration, and history of the varieties of the human race.

Secondly. In the increased number of artists. Of these there 
are five; and let it be borne in mind that to them is committed the task of delineating not only every object in the scenery necessary to convev a correct idea of the islands visited, the exact physiognomy and appearance of the natives, their manufactures, habitations, \&c., but also of portraying numerous species in natural history, of which the representations are required to be exceedingly minute and accurate; and through these means of fixing by ocular demonstration what words alone can never convey with that correctness so indispensable in the details of science. Were it possible to reason with you in any matter connected with this measure, it would be easy to show that the number of artists should be augmented. Most certainly, a decrease in their numbers would seriously affect the interests of the expedition.

Thirdly. In the selection of professional men for each distinct subdivision of scientific inquiries, who are expected to devote their exclusive attention to that branch of science which has been more immediately the subject of their investigation, is the number of departments to which principals have been appointed too great? You say that such is the case; but the reply is conclusive that this division has been made in accordance with the suggestions of persons of the first scientific attainments; and that there is no one of the departments which is not considered to be of sufficient importance to form a science of itself, and to have professors during their whole lives solely devoted to its cultivation!

Fourthly. In the appointment of a meteorologist and mechanical philosopher, not merely to make barometrical and thermometrical experiments, but an individual uniting a thorough knowledge of the properties of matter with a capacity for acute original research.

Fifthly. In zoology. Here, instead of a single zoologist, with four or five assistants, aide naturalistes, the respective branches are allotted to different naturalists, each of whom, however industrious, has an ample ficld for his labours. The zoologists, therefore, will not be merely collectors sent out to grasp up animals and preserve specimens for home inspection and dissertation, but men of high acquirements sent out to study the organic world alive. Zoology, in addition to that of the animal world, includes the physical history of the varied tribes of man. It is to zoology chicfly that anatomy is now looking for light; and many animals, 
hitherto only known through the medium of books, may be submitted to the anatomist during the contemplated voyage. The variety in the structure of living beings is immense; almost every distinct creature having some peculiarity of organization, and affording opportunities to elicit truth. 'The same zoological laws influence ourselves and the meanest insect; and the muscle which moves a finger at our wish, we know not by what secret connexion between will and motion, acts from the same cause as does that which controls the foot of a fly.

From a corps organized on the present plan great accuracy of research may be expected. Such has not been uniformly the result of expeditions despatched to the Pacific, nominally for scientific purposes, by the "maritime powers of Europe." With the facilities which the men of science attached to this expedition are afforded in their preparation, and, more than all, from the principle of the division of labour that has been adopted, a decided improvement, even on "the most successful of the expeditions sent out by the maritime powers of Europe," may be fairly anticipated; and this, you will find, the learned on the other side of the water will not hesitate to acknowledge. Divided as their labours are, they will be able to go over their ground thoroughly, and to glean all possible information on every subject which comes within the scope of their researches. Sir, would it not be honourable to our national character if the observations and collections made through the agency of our own naval and scientific intelligence should be distinguished above all others by their accuracy and completeness; and if, when any doubt was raised concerning the position, natural history, or language of any island, an appeal to the records of the South Sea exploring expedition should be sufficient to set the question at rest? Sir, the man is to be pitied who could not find more pleasure in the contemplation of such results than in darkly brooding over the ways and means by which he might prevent them; but, while he is to be regarded with commiseration for his want of sympathy with noble impulses, I think you will own that the power to crush or cripple their designs should be raken from him.

I have spoken of the number and qualifications of the members of the civil corps, as well as of the apportionment of their duties. I would now say a word in reference to the preparations they have 
made. 'This is the more necessary, as you are at present throwing, or striving to throw, discredit upon the undertaking, by reprobating these preliminaries as extravagant. I know that you do not pursue this plan on all occasions; but at the time and place, and in the presence of persons, when, where, and on whom you think it will produce the most effect.

You stated, in a report to Congress in February last, that " all the books, instruments, and charts necessary for any scientific expedition had been procured;" though, in your present report, you are obliged to own that "it was necessary" (after the date of that assertion) "to procure a great variety of articles for the gentlemen of the scientific corps." On the 29th of August and 12th of October you placed money in the hands of Commodore Jones, as also, to a small amount, in the hands of two members of the corps, and then told us that "this umusual course was adopted that there might be no delay in the sailing of the expedition." What mockery, I had ainscs! «: $d$. "vhat trifling with the intelligence of the country, is this flmsy justification of your tardiness of action! If you had put this fund into the hands of Commodore Jones in October, 1836, instead of October, 1837, and in other respects performed your duty, you might have been indulged in speaking of your "unusual course" to prevent "delay in the sailing of the expedition."

You were at Philadelphia in July last, and, by appointment, met a portion of the members of the corps in the hall of the "American Philosophical Society." A number of scientific gentlemen besides the corps attended. You then found that, so far from everything necessary having been procured, as stated in your report of February last, almost every requisite was still wanting; and this, be it remembered, was fifteen months after the authorization of the measure by Congress. You were liberal, however, in your expressions at that interview, and said you wished the corps to have a full supply of every necessary article, and even "a little more." Fortunately for the defence of this portion of the enterprise, the parties concerned were not the sole judges of what was required for their use in bonks, instruments, and other appliances. A commission of six distinguished members of the "American Philosophical Society of Philadelphia" was organized to examine into and judge of the propriety and 
utility of the requisitions made by the members of the corps, each for his own department. This commission consisted of the following gentlemen, whom to name is to guaranty that whatever they approved was correct: Peter S. Duponceau, Chairman, Professor Robert M. Patterson, Director of the Mint, John K. Kane, Esq., Clement C. Biddle, Esq., Professor Henry C. Vethake, and George Ord, Esq. This commission devoted its time to a careful and rigid investigation of every requisition made by the corps; conferred with the members of the latter; and, finally, approved every purchase or preparation of consequence which had been made; and, without its sanction, nothing agreed upon by the individuals of the corps themselves was conceded by your department. Nobly, sir, did the commission meet and discharge the duties which a devotion to the interest of science, and a pride in what the country was about to do, could alone have induced them to assume. They exhibited no narrow views, but were liberal, though not too much so; and in the result of their examination the country has every security for the fitness of the organization which has been adopted and of the preparations made.

It was, of course, to be expected that, in constructing the plan of an enterprise so extensive and so important, some imperfections of detail would unavoidably occur; but I think I shall be able to show, in my next letter, that a comparison with the "most successful expeditions sent out by the maritime powers of Europe" will demonstrate, that any attempt to reduce its numbers or alter its organization would be the most direct mode of greatly impairing its usefulness, if not of rendering it a nonentity. During the long period which has elapsed since the appointment of the scientific attachees, each has naturally applied himself to a preparation for his particular division of art or science; and has collected books, procured instruments, and pursued studies, having exclusive reference to his designated duties. 'To break up the corps now, when those composing it have made their arrangements for a long absence, and laid in their stock of clothing and sea stores, would be not merely to frustrate many and wellfounded hopes, but to subject these gentlemen, in addition to what they have already suffered, to serious pecuniary loss. Such a course would be, in fact, a flagrant breach of faith; and yet, sir, you know that what you are now labouring to effect would pro- 
duce, should you succeed, this very end. Do you disclaim the intention? We shall see the value of the disclaimer by showing, in the first place, the adaptation of the present force to the labours to be performed; and the s that the reduction you are urging will derange, if not preclude, all faithful and accurate research.

'The arrangements for the accommodation of the corps in the Macedonian are now fully completed, and will, in every respect, enable its members to pursue their avocations without interfering with the necessary discipline of the vessel or infringing on the convenience of any other persons on board. All the officers of the ship, whether of the wardroom, the steerage, or the cockpit, occupy unencumbered the accommodations usually allotted to thern in a frigate. Commodore Jories caused a cabin to be constructed for his use on the spardeck, resigning the one usually occupied by him on the gundeck to the sole possession of the corps. It has been fitted up for their reception, and they have all fixed upon their respective rooms; each having ample space for convenience and comfort. 'There they have space for their library, which comprises at least one thousand volumes, rare and valuable works on the whole range of the sciences in octavoes, quartoes, and folios ; for theirinstruments ; and for the pursuit of their investigations; and there, also, do the artists find suitable facilities, as regards location and light, for the most delicate delineations of the pencil. On board the frigate, with all these advantages, would the whole corps be accommodated during the transit from the United States to the field of their active labours. Suppose, then, in reference to these labours, as I did with regard to those of the hydrographers, that the squadron had arrived at the group already mentioned when speaking of the latter; for the same illustration which applies in one case will hold good equally in all others. The frigate has come to anchor at Navehetevoo, where she will lie say a month before sailing for another station. 'This would give to the philologist leisure to pursue his studies. A station would be taken on shore where magneric and pendulum observations would be made, for without such a ficility they could not be carried on. 'The presence of the frigate would give safety to the communications with the shore. 'The botanist, the entomologist, would, under proper escort, proceed to the interior, and the productions of the shore, the valleys, and the mount- 
ains would come under their cognizance. This plan of visiting the interior opens a rich field to science; one that has been but scantily occupied and superficially examined by expeditions originating with the "maritime powers of Europe." Islands thus explored would, if even two of them should be found clothed with sandal wood (to say nothing of other articles of traffic which have already entered largely into our commerce with the Pacific), repay to the nation the entire cost of the expedition. The physical force always at hand would perpetually facilitate research in every branch. 'The same boats used in surveying the harbour of an island would serve to debark the naturalists on its shores; and the same force which would be required by the commander in his intercourse with the natives could likewise protect the civilians in the performance of their several duties; while the completeness with which the corps is organized would enable its members to pursue their researches with rapidity, and make their calculations without delaying the expedition for any length of time; so that the period required for scientific researches at the largest islands would suit exactly that necessary for the movements of the frigate while directing the hydrographical surveys. But still more. One decided advantage in the scale upon which this corps is formed, and which gives it a superiority over mosit others hitherto sent out, is, that it is constituted of men more capable of taking charge of separate departments. Instead of being merely a body of collectors, acting under one or two heads, here each savan has his favourite division; while possessing, at the same time, more or less knowledge of the branches consigned to his companions. This will enable the men of science to adopt a perfect system of reciprocity. 'The botanist, while plucking a flower, would not overlook the insect feeding upon it; because. the entomologist would repay the courtesy by gathering for him a plant; and each would be able to give to the other all requisite information of their respective localities. This system would be carried out, in iike manner, with all the rest. All ground for jealousy would be removed by this division of labour; each member must stand or fall in accordance with his industry and ability, or his want of these qualities in his own department. An additiona. inducement for reciprocal services exists in the fact, that all which any one can do to assist his companions will be more than repaid 
by what they can, conjointly, do for him. Thus the individuals of the corps may separate, as occasion shall require, and a part of them accompany the small vessels in their exploring excursions; bringing, by these means, all portions of a group or island under observation and contribution; while such researches as cannot be made without spending considerable time at a single spot will always be the province of those on board the frigate, which vessel will constitute the floating friendly port and homestead of all. To her all would return when the desired objects at any particular station had been attained. 'The hydrographer (and, in fact, every officer would be a member of the hydrographical corps) would carefully analyze and arrange the materials gathered in each survey, and consecutively imbody them in one continuous chart; while the commander, after having directed all these varied employments, would see that the results were clearly and faithfully recorded, so that they should, through all coming time, prove a guide to the mariner who followed in his track. The corps, laden with treasures from every portion of the group which they had separated to examine, would again meet on board the frigate, from which they might, some of them, have been absent for several months. Here, without incommoding others, or beings themselves incommoded, with the appliances of an ample library, the use of instruments, and the assistance of artists, everything could be analyzed and delineated, to be afterward labelled and carefully preserved; for all which operations there would be a sufficiency of room. 'Thus, sir, it is apparent that no less to the success of scientific inquiry than to the proper accomplisliment of the great objects of survey, friendly intercourse with the natives, and the protection of our commcrcial interests, is the frigate indispensable. Without her the expedition may be sent out, but it will reflect comparatively litule honour on the senders.

If rumour speak true, your recent commission, consisting of Commodores Hull, Biddle, and Captain Aulick, without having visited the squadron, and certainly without having had much time to examine the real purposes of the enterprise, have given a report which pleases you; inasmuch as it is said to recommend the substitution of the sloop-of-war Peacock for the Macedonian, and a diminution in the number of minor vessels. I cast no censure upon this board, not having seen the instructions under which 
they acted. For the sake of illustration, let it be supposed that you succeed in your plans, and commence a reorganization. The Peacock is a second-class sloop. Her wardroom will scarcely accommodate her officers, and the cabin on her gundeck is, of course, appropriated to her commander. Where will you put the gentlemen of the corps? Where will they eat ? Where will they sleep? 'Their library, their instruments, their storeswhere are these to be stowed away? Their studies-in what portion of the vessel are they to be carried on? Where do you design the artists should work? Sir, it is idle to discuss the point; what you are now trying to do will break up the scientific association, and you know that such is its tendency, that such will be its issue. By crowding the savarts on board the several vessels you interfere with the limited space and comforts of the watch-officer; and feeling this to be the case, thcir usefulness would be destroyed. 'Then, with professions of extreme regret, you will say their numbers must be reduced. Can you reduce them without making their labours a mockery? Can you do it without blasting the hopes, and trampling on the pride and just cxpectations of the country? Let us see, sir, how your reductions are to be made. Take up the list, and begin, to you, the welcome task!

First, the philologist: will you dismiss his name from the catalogue? "Every new language is a new development of the human mind." If the great study of mankind be man, surely his most remarkable attribute-speech-should not be neglecied. The science of linguistics, or comparative philology, has reccived marked atterition, and is held in the highest estimation in this country ainong men of gifted minds, if such individuals as Duponceau, Anthon, Galatin, Gibbs, Pickering, Webster, and others of high attainments are entitled to that distinction; while in Europe, and especially in Germany, it receives the exclusive devotion of some of the most learned men of the age. Wonderful results have attended the progress of this comparatively recent science, and still more astonishing developments may be expected. It travels back to remote ages, far beyond the date of authentic history, and shows the affinity among the rarious tribes of our race, however they may be scattered over the face of the globe. Indeed, by this science alone can the early migrations of man be 
traced. How glorious, then, for this country to be the first to extend her inquiries in this deeply interesting department of human knowledge among the groups of the Pacific. But I must conclude my renarks upon this very interesting theme. Sir, you cannot dismiss the philologist!

In the department of natural philosophy or physical science there is but one individual, and, of course, he cannot be dispensed with.

Chymistry, mineralogy, and zoology, including organic remains, will surely be allowed to afford ample scope for two, when it is remembered that several professors find more than they can do in this branch within the limits of a small state, though industriously employed for years.

Your own attainments in botany, so often made manifest in descanting on the flowers of a bouquet when in the hands of youth and beauty, will, I am sure, secure to the expedition the botanist and his assistant.

The department of zoology is well and ably filled by four naturalists, exclusive of the comparative anatomist. Pause and reflect, sir, before you make war on this division. Remember that zoology has ever been a leading object in scientific voyages. Look at Cuvier; examine his labours well; and you will find that, vast and comprehensive as were the researches of that great zoologist, he yet confined himself to but a portion of animated nature. Your "naturalists," your "scientific men," often have been exclusively zoologists, and, in most instances, the number of professed zoologists sent out by the "maritime powers of Europe" has been confessedly too small. The science is that of life, and the most valuable observations are drawn from life. The nembers of this great division will find, during the voyage, more, vastly more, than they can perform, in observing the living world. Vain and presumptuous would be that man, therefore, who would at this day undertake all the branches of zoology. Such a man might make collections for a museum; bring back specimens; remnants of death for the inspection of closet philosophers; but the vastness of his undertaking would place him, in the scale of naturalists, about where a pedler of Brandreth's pills might be supposed to take rank among regular physicians. How, then, can you cut down in this division? Answer, not to me, but to your country, whose glory you would mar. 
Of the artists I have before spoken. Their number should be augmented rather than curtailed. Numerous specimens in botany, a vast variety of fish and other objects, will require delineation at every rendezvous before they shall have changed their natural state; and there should be no delay in these matters. 'Tivelve thousand dollars would employ two more artists during the voyage, and it would be economy to engage their services. Surely, then, you will not lay hands on the fine arts!

'Thus you see, sir, that in every form and aspect in which the subject can be reviewed, the rationale and argument are in favour of the frigate and other vessels as now prepared. Equally apparent is it that the alterations you are now urging are virtually destructive to the entire enterprise. Razeed as you propose, it would not meet public expectation, and the nation could fecl but little pride in it. It would fall short of what some of our state governments, even those most adverse to expenditure, are now doing by the employment of men of science, with large salaries, in examining the natural history and geology of their respective territories; and it is well known that, in a pecuniary point of view, those governments have been repaid a hundred fold for their outlay.

Sir, in your report to the president in December, 1836 , you acknowledged that the " indications of public opinion" were in favour of the expedition being prepared and sent out on an efficient and liberal scale. I put the question to you direct; has there been any change in the "indications of public opinion" since that time? Among the journals of the country, all of which have appeared to meet upon this point as upon common ground, few, if any, have expressed dissatisfaction at the original arrangement.

The most distinguished societies, literary and scientific, in the United States, have not only manifested increased interest in its complete preparation and opposed its curtailment, but have thrown open their libraries for the use of the expedition, offering the use of any books upon their shelves. Foreign societies, both in private correspondence and by public resolutions, have expressed, in the strongest manner, their anticipations of the benefits to be gathered from its researches.

Indeed, not only our own country, but the nations of Europe, would hear of a determination to reduce the naval force of the enter- 
prise, and the number of its scientific observers, with equal surprise and derision. 'They would recollect that, forty years ago, France, with her finances disordered and energies apparently taxed to the utmost by a long and expensive war, and England, when similarly situated, both sent out splendid expeditions of discovery. The former detailed a numerous corps of savans, which accompanied the memorable army of Egypt, requiring that particular attention should be paid to facilitating their labours.

They will remember, moreover, that whatever the military renown which was reaped by France on the Egyptian plains, it was not greater or more imperishable than that which accrued from the investigations of its scientific attachees into the natural history, the topography, the antiquities of the country. With these reminiscences they would be excusable in receiving the news of such an unjustifiable sacrifice as that proposed, though urged on the plea of economy (after the whole expense of preparation had heen incurred), with feelings as much akin to contempt as astonishment.

In my next I will hold you to a comparison of this expedition with what "the maritime powers of Europe have done ;" and will show that, if the naval appropriation for 1838 must be reduced, the cxploring squadron is the last object to which, if we have a due regard for our interest and honour, that reduction should be suffered to apply.

I have the honour to be,

Very respectfully, your fellow

New.York, January 1, 1838

CITIZEN.

\section{XII.}

To the Honourable Mahlon Dickerson, Secretary of the Navy. Sir,

Had you been more specific in your frequent allusions to the expeditions sent out by the maritime powers of Europe, from be. hind the models of which you so frequently assail the arrangements made for the first similar enterprise from this country, it had been a much easier task to meet and confute you; it had 
been a task, also, much more concisely performed. Sir, had you looked at your countrymen in all that belongs to their history, you had leamed that in all things wherein they have been distinguished, in every undertaking in which they have been most successful, they have been anything but servile initators of the nations of Europe, in the quo modo of their actions. 'They did not study foreign models (except to improve upon them) in framing their institutions, nor in subduing the forest and turning the wilderness into the abode of civilized man; nor in their steam-navigation and mechanical agents; nor, above all, in their ship-building and commercial enterprise. Our people, though the last to enter the Pacific, have been chained down by no precedent in their movements there, but have pushed their ocean business in that quarter far beyond that of all other nations. Before you urge as authority what the maritime powers of Europe have done, it is incumbent on you to show that these powers had equal interests afloat to be protected and cxtended; that the motives which prompted their efforts were the same and as imperative as those which have produced action in our own governnent; and, unless this can be shown, it is idle to talk about models. 'The force to be employed in any enterprise should be regulated by the consideration of what that force is designated to perform.

The exposition to which I have alluded I might, with propricty and justice, require; but, not supposing you would find it convenient to give it, I waive my right to interrogate you on this point, and proceed to show how little, in all probability, you know in detail of the expeditions to which we are so triumphantly referred as patterns for our own.

Most of the early expeditions to the Pacific were despatched there rather to plunder the Spanish settlements and to make conquests than for the purposes of discovery. 'They originated in high daring and an ardent thirst for adventure. But I presume you will not hold them up as models at this day, unless, indeed, your statement, that the officers of our navy entered the service with a view to distinguishing themselves by deeds of arms, hinted at their emulating the forays of the bucaniers, in preference to the more peaceful exploits of modern discoverers. There are, then, but comparatively few enterprises of discovery with which I need stop to institute comparisons. I will take those of most 
celebrity. As regards the English expeditions, I need not go farther back than that of Cook; and, among the French, to that of Dentrecasteaux. (Of what, sir, did the latter consist, and what were the objects it was fitted out to attain?

In 1781, as no news had been received of La Peyrouse for three years, "the Nitional Assembly decreed that the king should be desired to arm one or several vessels, in which should be embarked scientific men (savans), naturalists and draughismen, and to give the commander the double mission of scarching for La Peyrouse, and maling, at the same time, researches relative to the sciences and commerce; in taking all measures in rendering that expedition, independent of the primary object, useful and advantagenus to navigation, geography, commerce, and the arts and sciences."

Nothing like general exploration entered into the plans of this voyage, and yet Dentrecasteaux required of the government two vessels of five hundred tons each. In this mission, acquisitions in geography, commerce, navightion, and the arts and sciences, were secondary objects; and yet there were attached to these vessels two astronomers, two hydrographers, five naturalists, two gardeners, and two painters. Comparing, then, the limited range marked out for that undertaking with the wide sphere of our present enterprise, and contrasting the necessary minuteness in scientific research at this day with the far inferior accuracy which consisted with the state of science then, you will find that, as regards both naval force and the number of scientific observers, you are totally unsustained in your position; nay, that you must add to rather than subtract from the force of the expedition as already organized.

Come, sir, let us proceed with the comparisons you have provoked, and prepare to stand or fall by the issue. You have used the words "recent voyages," and, for the sake of brevity, I will come down to them. "The voyage of Captain Freycinet in the Unanie, from 1817 to 1820 , has been greatly and very justly celebrated. He had a corvelte of twenty guns, and one hundred and twenty men, besides officers. Here is a model that suits you; one to which you have impliedly referred Congress in justification of your present course; yet you might, with about as much propriety, have cited the equipment of Lewis and Clark for their excursion over the Rocky Mountains as a pattern to be followed in 
this expedition. Would you send the same force to fight the King of the Sandwich Islands as you would to humble the Barbary powers? Certainly not. And why? Because what was amply sufficient for the one object would be totally inadequate to the other. Very good. Now let us see, sir, what object the French government had in view which Captain Freycinet was despatched in a single corvette to effect.

"The principal ubject of the voyage," says Arago, "was to ascertain the figure of the globe by pendulum experiments, and the elements of terrestrial magnetism; several questions in meteorolegy had also been indicated by the academy very worthy of attention."

Freycinet himself superintended the pendulum experiments, assisted by ten out of seventeen of his officers; and during the whole voyage not a single series of observations was made in which he did not take the principal share. 'Thermometrical and hygrometrical observations were made hourly both by day and night; examinations of the barometer every two hours; and, at the same intervals, of the temperature of the sea. In the first chapter of the narrative Freycinet says: "Our expedition is, I think, the first maritime voyage which, being destined to the progress of human knowledge, has not had hydrography for its object. The determination of the form of the globe in the southern hemisphere, the observation of magnetic and meteorological phenomena, finally, the study of the three kingdoms of Nature, formed the principal object of the mission."

Thus you perceive, sir, that in this French expedition hydrography was even less than a secondary object, while in the American it is one of the most prominent. In the former, the protection of commerce, the rescue of shipwrecked mariners, the survey of important groups, islands, and harbours, were altogether minor considerations; indeed, were not even named; while these constitute important provinces of the latter, and have been especially prayed for in the memorials, upon the representations of which Congress has based its action. Do not these facts show the absurdity of attempting to draw a parallel between the two undertakings, and of endeavouring to make the scale of one an argument for the reduction of the other? To Freycinet was granted the entire selection of his own officers. How will your conduct 
in this respect compare with foreign models? "With regard to provisions," says Freycinet, "everything was allowed that could be required, and extra clothing was furnished for each man gratis."

Large quantities of concentrated or fresh provisions were furnished, and the commander has shown that the government saved money by this liberality; to say nothing of the preservation of health to which it was conducive. How did you follow this foreign model in reference to extra cluthing? I will answer. When the different rendezvous for the shipment of seamen for the expedition were first opened, wages in the merchant service were high, and recruits came in slowly. Again and again did Commodore Jones urge the necessity of promising the men an allowance of extra clothing, as well as the bounty authorized by Congress even for the general service during the past year; but you refused to hold out the hope of either. Finally, however, when, under every discouragement, the complement of men had at length been shipped, you graciously condescended to allow both.

Making you perfectly welcome to all the support the voyage of Freycinet can afford you, I will now leave it and take up another; but not till I have informed you that this commander lost his vessel at the Falkland Isles; from which extraordinary fact you will perceive that a corvette may be wrecked as well as a frigate!!

Next in order of time comes the voyage of Captain Duperrey in the Coquille in the years 1822, ' 3, ' 4, ' 5 , seventy-two persons. And for what was this vessel sent out? 'To hold conference with the islanders of the Pacific, protect commercial interest, make surveys, \&c., \&c., \&c., and to combine with these accurate scientific research? Look at the work, sir, and you will then find that the "objects of the voyage were again the study of the three kingdoms of nature, magnetism, metcorology, and some observations relative to the determination of the figure of the globe." As to hydrography, it "was proposed to establish or rectify the position of a great number of points in different parts of the globe." 'The character, language, manners, \&c., of the islanders were also to receive attention.

"'To establish harmony," says Duperry, "we agreed beforehand to divide our labours according to our predominant tastes."

M. Durville, Botany and Entomology. 
M. Garnot,
M. Lesson, all the rest of Natural History.

M. Gabert, Agent, Commerce and Industry of the Natives. M. Lejeune, Draughtsman.

M. Duperrey, Physic and Hydrography. Seven assistants.

Thus, sir, notwithstanding the limited sphere of action to which the labours of Freycinet and Duperrey were confined, in comparison with the vastness of that marked out for the South Sea exploring expedition, fifteen persons accompanied the former and twelve the latter commander, who were engaged directly in scientific researches.

From these $t$ wo celebrated voyages, then, you may learn two things: First, they were not fitted out or intended for the duties expected to be performed by the present enterprise; and, secondly, that the scientific corps were more numerous, in proportion to their ficld of action and number of vessels ; though not so well organized, as regards the division of duties, as the present. In scientific results the voyage of Duperrey was decidedly inferior to that of Freycinet, who preceded him; and even were this government about to send out a single vessel for objects precisely similar, the former ought not be selected as a model. Duperrey had but a meager supply of instruments, and only five chronometers. 'The nean maximum irregularity of these chronometers varied no less than twenty-three seconds and a fraction per day. Would you have the mean maximum irregularity of those used in this voyage to run thus? Duperrey made no experiments on the temperature of the sea at great deptus; nor was he provided with a single self-registering thermometer. Would it not be best to sell those provided for this expedition unless we can find authority for using them in some of the olher expeditions sent out by the "maritime fowers of Europe?" Duperrey "was authorized to appoint his own officers," the same privilege which had been allowed Freycinet. Mark that!!!

Captain La Place made a pretty little voyage round the world a few years ago in the Favourite, of seven hundred tons and twenty-four guns. What do you think of his enterprise as a model? What did he do? Where did he go? After doubling the Cape of Good Hope he followed in the well-known track of modern voyagers. He run down the African and Indian Oceans, passed 
the Straits of Molaccas and entered the China Sea, which he left by passing to the east of Java, to the west and south of New-Holland, and south of Van Diemen's Land. 'Thence returning northerly, he visited New-Zealand, from which he sailed by the most direct route to Valparaiso, and then proceeded round Cape Horn and hoine. I question if you could have marked out a route more barren of interest than that which he purstled. He took with him no men of science, and gave to the world on his return a portfolio of landscape drawings! Would this modern effort of one of the "maritime powers of Europe" be a suitable pattern for the naval enterprise of this country? It is not necessary to allude to the English expeditions and discoverics. 'Those which they have recently sent out under King, Owen, Foster, \&c., can form no examples for this country, as Caplain King was employed in surveying the Straits of Magellan and the east and west coasts of Patagonia; Orven on the coast of Africa; Foster in making a few pendulum observations.

Sir, I will not pay your judgment so poor a compliment as to credit, for a moment, that you could regard the expeditions of Ross and Parry, sent out for the sole purpose of making their way along a frozen coast and among numerous islands in the polar seas to determine a single question in physical geography, as models for this expedition; though I have seen these same voyages, by genthe implication, held up for that purpose in the report of a committee of the Navit Lyceum at Bruoklyn, who seemed to feel under increased responsibility for their opinions from the circumstance that they might be regarded as representing something like three hundred naval officers!!!

I come now, sir, to the last great effort of the maritime powers of Europe, as given to the world in the voyage of the Astrolabe. A copy of this work was sent a year ago by the French as a present to our goverument. It was a prelty conception, honourable to the French; and it will be honomable to us when we shall be able to return the compliment. How often has this voyage been the theme of your remarks? How often, nay, how constanly have you relied on this voyage as a model, and as a justification of your late proceedings? It lias been a sort of stalkinghorse for you, upon which you have endeavoured to ride down the present expedition. But, in sober truth, have you really got be- 
yond the pictures in an examination of this work, great as it is and splendidly as it has been brought out? I very much question if you have. At any rate, I hold you to the comparison even with this voyage, and deny that from its pages any warrant can be derived for a reduction of the naval force or number of scientific observers in the exploring expedition. You have the work before you, so have I; come, then, to the comparison. 'This voyage was made in the years 1826, '7, '8, '9, in the corvette Astrolabe, Captain D'Urville, with eighty persons, all told. What were its objects? They are set forth in the following extract from the instructions of the minister of marine, the French secretary of the navy, to the commander.

"The king, in confiding to you the command of the corvette Astrolabe, has wished to put you in a situation to explore some of the principal groups of islands in the Pacific, which the $\mathrm{Co}$ quille only passed by hastily, and to give you the means of augmenting, as much as possible, the mass of scientific documents obtained by this vessel in the years 1822, ' 3 , '4.

"His majesty knows that you contributed much to the success of this expedition, in which you seconded Captain Duperrey. Being called to direct in chief the present one, you will realize, without doubt, all the hopes which have originated the project; and the French navy will have to felicitate itself once more upon the services which it renders to the sciences in associating itself to the labours of those who profess them, and in submitting to their mediations materials collected with as much slill as zeal in all parts of the globe."

These instructions point out the purposes of this royage. They were to follow, measurably, in the track of the Coquille, and, at various points in the Pacific, to make morc minute observations where the other vessels had passed by hastily. 'The models of the preceding enterprises had been followed in preparing this: while, with the exception of the attention paid to pendulum observations by the former ones, their general objects were precisely the same; and neither furnished any precedent for the strength which the great interests of this country require should be invested in our own expedition to those seas. Indced, the most that can be said in favour of this voyage, constituted as it was, may not be too high praise; though I am inclined to be- 
lieve that nearly as much, after all, was done in Paris to make it pre-eminent in the way of embellishments, and in the commendable style in which the French government got out the work, as was effected by D'Urville in the South Seas; nevertheless, the contributions to science were great, and I doubt if the French people would be willing to resign the honour conferred upon them by that voyage alone for a million and a half of dollars! and yet the citizens of France think as much of money as we do. Let us, however, go somewhat more into detail, as I feel that I have you now on the last plank, and intend to remove even that from beneath you. What were the contributions made to zoology by the naturalists of the Astrolabe? Rich, you will answer. Granted. But by whom were they made? By any one appointed by the government? No, sir, the voyage would have fallen below mediocrity in this important and leading division of science had it not been for M. Quoy, a volunteer in the expedition. In geology, too, the only collections were made by the same gentleman. Would you follow this example? Would you have a great nation, when making its advent in maritime discovery, depend on adventitious aid? Would you urge this as a morlel?

Let us next take a glance at this model of models in its other departments of science, and see what there is to be found to warrant your proposed derangements in the scientific portion of the exploring expedition. 'The metcorological researches consisted of observations on the thermometer six limes a day, barometer once a day, on the direction and force of winds, and general remarks on the direction and speed of currents. The experiments of Freycinet and Duperrey were on a far more extensive scale. 'The only marine thermometer taken out by D'Urville was broken fifteen months after the commencement of the voyage, and, consequently, the column recording the varieties of pressure is, after this date, a blank. Don't you think this part of the model would have been nearer perfection if the French secretary of the navy had furnished, at least, duplicates of instruments so liable to fracture?

'I'wo of the four chronometers taken out by Captain D'Urville were rendered useless, one by heing carelessly wound up, the other by firing a salute. The remaining pair had very variable daily rates, and both ran down at 'Tonga 'Tabou. Do you not 
feel half convinced that this part of the model might be tinkered 2 little for the better?

Observations on the magnetic dip present rather a meager record. They were by no means equal to those made during the two preceding French voyages, or by the late English expeditions to the Arctic Sea. Indeed, all the needles appear to have been spoiled during the voyage, and great discordances appear among the results given by different needles at the same locality; they were only used, however, at sixteen places on shore. By the "sweet flowers of Suc-a-Sunny,"* you are ready to exclaim, "what ignorance, what presumption is this ? Attempt to criticise this great work, on which I have preached so much to members of Congress, to the president, to everybody who would listen to me!" Be patient, sir. If your zeal to defeat or cripple the exploring expedition has placed you in an untenable position, the indiscretion is your own, not mine; and you must abide the issue. Yes, sir, prepare for utter confusion and defeat, when I tell you that all and much more than I have said of your venerated model is sustained by the opinion of the great Arago, the imbodied soul of the science of Europe ; and if it were not, the committee of the Naval Lyceum in their report have endorsed his wonderful attainments, and fixed for you the standard of his authority.

"In 1829 , immediately after the return of the Astrolabe," says Arage, in his critique, "Captain D'Urville presented to the Academy of Sciences a series of works of every kind executed during the long voyage of that vessel. Before the same body he read his memoirs, and solicited its judgment; and a commission was accordingly appointed. M. Rossel made a favourable report on the hydrographical part of the voyage, designating the officers who executed the work. On the 26th of August, George Cuvier paid a just compliment to the ability and zeal of the zoologists of the Astrolabe, M. Quoy, the volunteer, and his assistant, Gaymard." M. D'Urville is complimented in the report as having "personally collected a part of the insects of the collection deposited in the garden of plants."

On the 16th of November a tribute of praise was again awarded to M. Quoy and his assistant, M. Gaymard, for the geological specimens they had brought home; and, finally, the venerable

- Name of the honourable secretary's country residence in New-Jersey. 
Des Fontaines spoke flatteringly of the botanical collections of M. Lesson. It was, indeed, flattery to speak highly of the botanical department of the Astrolabe, as we shall see anon. Arago was charged by the academy with the examination of the physical observations. He did not wish, he said, to confine himself to a simple inventory. As in the voyages of Freycinet and Duperrey, he attempted to discover the results with which science would be enriched. But here "disappointment followed disappointment." Discouraged "by the poverty of scientific observations recorded in the official registers," he examined the nautical journals. Here, again, he was disappointed; while those of the former navigators had been so varied, so rich, so interesting. The farther he advanced in his investigations, the more forcibly was he impressed with the idea that the commander of the Astrolabe had voyaged for three years " with his eyes and ears shut." "Had he" (D'Urville) "seen," Arago inquired, "the zodiacal light? During the fine nights of the tropics, had he ascertained its dimensions, its limits, its exact position? He had turned, one after another, all the pages of the register of M. D'Urville, and was not able to find one remote allusion to this remarkable phenomenon." Not yet disheartened, the transparency of the ocean, the changes of colour produced by the winds, according to their force and direction, the sudden variations of temperature, upon which Franklin and Williams had already published the commencement of a work so encouraging to the marine; the Aurora Australis; each of these curious phenomena, the exact determination of which has been sought with such ardour by the students of physical science, was, Arago says, in succession the object of his laborious research; but in every case he arrived at the last page without having found a word upon the subject.

At the frequent solicitations of Captain D'Urville and M. Tasteau, the editor of the voyage, $\Lambda$ rago was prevailed upon, as he says, "by the desire of obliging more than anything else," to make out a digest. He had found here and there in the MSS. observations on the temperature of the sea, which, at that time, he supposed were correct; but many of these experiments he subsequently found "were complete failures," though even these were not without their use for future observers. It was especially desirable to determine if submarine currents, directed from the 
poles towards the tropics, were not the cause of the phenomena roticed. It seemed probable that this question might be solved by thermometrical observations made for that purpose. These were made on board the Astrolabe, but were they conducted with sufficient exactness? Arago says he "does not hesitate to answer in the negative," and then procecds to point out the errors committed. Indeed, after a long and minute analysis of the results of the voyage, he remarks, "it is now certain that, in cases of the most simple observations in the world, M. D'Urville has escaped none of the errors he could possibly commit."

Now, sir, I can readily imagine the surprise created in your mind at what Arago has said of the results of this voyage, for a full account of which I refer you to a late number of the "Review of the 19th Century." How is this unsatisfactory issue to be accounted for? I will tell you in one line. Among the persons engaged in scientific observations on board the Astrolabe I find “M. D'Urville took charge of botany, entomology, meteorology, geography, historiography."

You have the solution, sir. D'Urville undertook too much, and failed; and so will this expedition fail if you are permitted to cut it down and reduce its naval and scientific corps. Human science is too vast and too minute at the present day to allow of any man taking so wide a range as that referred to.

In the volume of the voyage of the Astrolabe devoted to hydrography, one eighteenth relates to the Fiji Islands. 'The space occupied in the work by observations on this archipelago is very considerable; on which account I select that portion for "comparison ;" and here you will find your beau ideal of voyages is a model only to be avoided. On the 25th of May Captain D'Urville came in sight of the Fiji Islands, and passed by Ong-Hea Riki. He was eighteen days in making his way through this group, during which time he never anchored, nor did he make a survey of a single harbour. He did not even send a boat on shore, except at one place, and then only for the purpose of getting off an anchor left there by some former vessel; in allusion to which circumstance he remarks that "the natives appeared more disposed to retain the boat than to give up the anchor." When D'Urville approached a cluster of islands, if the weather were clear, he first made up his mind by sight alone whether they were five or thirty 
miles distant, more or less, and then, by the old method of taking their bearings by compass, made out their latitudes and longitudes with wonderful accuracy, not only in degrees, but even down to minutes and seconds. Was the day hazy, he went through the same process of guessing at his data, and then drawing his conclusions with mathematical precision. Fortunately, the natives boarded him and gave him the names of the islands. In his "Tableau des Positions," one hundred and ten islands of the two hundred which this group, in all probability, contains, are thus conspicuously laid down; although the whole time, in daylight, consumed in making these mighty acquisitions to hydrographical knowledge gives only an average of two hours for the examination of each member of the cluster! Wonderful results! Beautiful model for the exploring expedition. Sir, this group, with all its riches in natural history, still remains to be examined. The plan of D'Urville's voyage, and the force at his disposal, were alike unsuited to the task; and what he accomplished, for all that it is worth to navigation, had almost as well remained undone. Three months is the shortest period that the expedition, with all its force, should remain in this archipelago!

As regards botany, your favourite science, the researches made during the voyages of the Astrolabe were, in like manner, exceedingly superficial. The only collections worthy of notice at all were those made at New-Zealand and Ascension; and even at those places few new plants were discovered. 'Three hundred and twenty species belonging to New-Zealand were known previous to D'Urville's visit there ; and on that occasion only one hundred and ninety species were obtained, three tenths of which had been seen and described in the voyages of Captain Cook by Sir Joseph Banks, Dr. Solander, Sparmann, and the Forsters, and in those of Vancouver, by Mr. Menzies.

M. Achille Richard, who prepared the botany of the voyage for publication, could not have had a very exalted opinion of the labours of D'Urville and M. Lesson in this department, for he has not confined himself to their collection, but has compiled a general Flora of New-Zealand, by copying the description of all the plants found there, from Cook's first voyage to the present time. In this branch, as in most others, your vaunted model was far inferior to the voyages of Freycinet and Duperrey; indeed, the relative value 
and importance of the three expeditions, so far as botany is concerned, are in the order of their priority in date. By far the most extcrisive and valuable collections were made in the earliest, that of Captain Freycinet; Duperrey's is next in rank; while the latest (that of D'Urville in the Astrolabe) follows longo intervallo, both as to the extent and interest of the specimens.

But although the botanical department of the latter expedition was more imperfectly filled than in either of the two which immediately preceded it, do not imagine that they were by any means sans reproche in this division. In each instance a capital error was committed in not sending out a botanical draughtsman. This deficiency was, doubtless, seriously felt by M. Gaudichard, the indefatigable botanist who accompanied Freycinet, as he was particularly interested in regetable anatomy and physiology, and must have frequently desired magnified drawings and slietches of dissections, \&c., which could only be made from the living plants. In none of these expeditions were any researches of consequence made beyond the coasts of the islands visited; while at some places (as Admiralty Island, the Carolines, and others), touched at by Freycinet, the time allowed for observation was so limited that M. Gaudichard did not even land; but was obliged to content himself with what he could obtain from the water. From the mate. rials collected, however, he prepared a digest of the botany of the voyage, from which he deservedly gained high reputation; and this is the only instance in the three enterprises where the person who collected the plants arranged and described them on his return. So far the model is a good one. Those who collect should be able to describe.

I trust, sir, you are now satisfied that a comparison of the organization, naval and scientific, of the "exploring expedition," with " the most successful expeditions of like character heretofore sent out by the maritime powers of Europe," will afford no warrant for your efforts at reduction. On the contrary, were it possible for you to take the enlarged and practical views of a statesman, as regards this subject, you would see the obvious propriety of increasing the number of small vessels, which additional force could be so advantageously employed in useful nautical labours, under the general direction and protection of the flagship, at an expense so trifling to the government. One would think, indeed, that a 
true "Friend to the Navy," occupying your station, would be anxious to employ as large a number of officers on a service so well calculated to give them high attainments as well as distinction in their profession; to make them personally acquainted with seas where our future seafights must take place; so that where they should command they could themselves be pilots! You would also perceive that the results of the expedition might lead to the formation of a hydrographical bureau in your department; in a word, that it would be of more importance to the navy than the service of all the force in all other squadrons during the same period!

I must now, sir, take leave of you, and, in doing so, would appeal, not to your candour, but to public justice, if I have not fairly met and completely overthrown your objections, stated and implied, to the magnitude of the scale upon which this expedition is organized? Have I not shown that the naval force authorized and the scientific corps engaged are barely adequate to the vast sphere of action to be embraced, the multifarious objects to be accomplished, and the mighty interests involved? Have I not shown that your outcry about economy was a mere cloak for your enmity; and that the remuneration of the country for its outlay would be almost in geometric ratio with its degrees of efficiency? Have I not shown that the almost limitless field for those hydrographical surveys so necessary for the protection of our widespread commercial interests in the two Pacifics could not be examined with the care which humanity as well as good policy demands, by an enterprise of inferior capacity? Have I not fairly met the comparisons you have invited, even with the climax of your models, the voyage of the Astrolabe, which you have culled par excellence from all the rest, and held up exultingly as a weapon of attack, a shield of defence, a precedent and a pattern? This voyage is in one respect, I own, worthy of all praise as well as of imitation; I refer to the magnificent style in which the whole work has been brought out! Have I not shown that, according to your reasoning, the Pacific squadron should be broken up or materially reduced? You have on that station a ship of the line, two sloops, and two schooners. On an average, half of this force is constantly at anchor in the bay of Callao, the principal port of Peru; while the cxports from the United States to that republic, 
for the year ending September, 1834, the latest returns within my reach, amounted only to fifty-eight thousand eight hundred and sixty-three dollars; the price of a single whale-ship.

Now in this account, as you have done with reference to the expedition, first put down the cost of the vessels, then calculate and add the amount necessary to the mission for three years, and behold what an enormous sum! The whole of our trade protected by our Pacific squadron has not amounted, since 1830 , to a million of dollars per annum; and, notwithstanding the unsettled state of the countries with which this traffic is carried on, they have no force to prevent a sloop-of-war and two schooners from exacting respect to our flag. What an argument here for reduction! But no statesman reasons thus. It is the settled policy of the country to have constantly available an efficient naval force. 'The exploring vessels should be regarded as a part of that force; and the only point at issue ought to be, whether this great nation could afford the outfits, and forty-three thousand dollars a year for the salaries of the civil corps !

Having now, as I feel, discharged my duty, it would give me pleasure to anticipate that, like a generous antagonist foiled in a hard encounter, you will yield with a good grace, as yield I think you must!!! Sorry I am to say, however, that I can find no precedent on which to base so pleasing a supposition. But where can you take a fresh stand? Let me hope in charity that your dernier resort, after the choice of a new commander, will not be once more to intrench yourself in inveterate obstinacy, and from behind that impregnable barrier to issue your dicta against science, humanity, commercial interests, and national honour!

Very respectfully,

I have the honour to be, your fellow

CITIZEN.

New.York, January 4, 1838.

THE END. 
$W 772$ 
